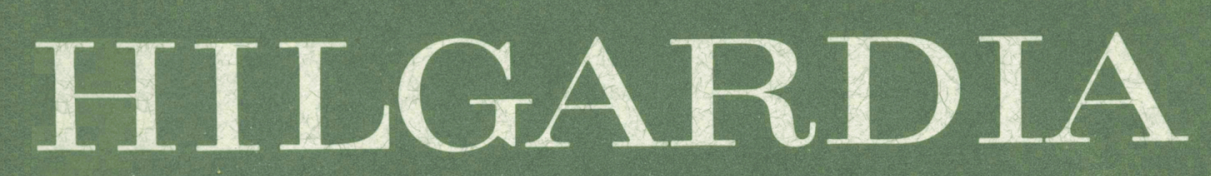

A JOURNAL OF AGRICULTURAL SCIENCE PUBLISHED BY THE CALIFORNIA AGR ICULTURALEXPERIMENTSTATION

Volume 46, Number $9 \cdot$ December, 1978

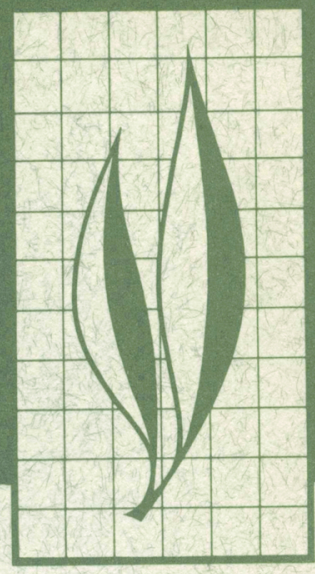

\title{
The Feral Hog on the Dye Creek Ranch, California
}

\author{
Reginald H. Barrett
}

END OF VOLUME 
From 1967 to 1970 , an extensive study was made of the life history and ecology of the feral hog (Sus scrofa L.) inhabiting oak woodland in the Sierra foothills. A detailed description of the feral hog included chromosome number, size, conformation, skull characteristics, dentition, tusk development, coat color, communication, social structure, and behavioral patterns. Home ranges of boars and sows were estimated to be 50 and $10 \mathrm{~km}$, respectively; hogs were capable of homing at least $15 \mathrm{~km}$. Acorns were the most important food item, but green grass and forbs, wild oats, berries, bulbs, roots, insects, and carrion were also eaten. Hogs grazing irrigated pastures during the summer consumed more green forage and crude protein and exhibited significantly greater growth rates than hogs without access to pastures. Pen-raised feral hogs were found capable of growth equal to domestic swine, but typical freeranging hogs exhibited growth rates of only half their potential. Sows bred continuously after the age of 6 to 10 months, averaging two litters per year and 5.6 young per litter at birth. Sows with access to irrigated pastures produced 20 percent more fetuses than those without access. From birth to 6 months of age, piglets sustained a 70 to 90 percent mortality. Losses were due to accidents, predation and starvation. Insufficient milk resulting from low levels of protein in the sows' diets was a major underlying cause of piglet losses. Hunting was the major cause of adult mortality. Tooth abscesses and related infections were the most important natural causes of adult mortality. Population density ranged from five to eight hogs per square kilometer on the $130-\mathrm{km}^{2}$ study area. Although the annual kill averaged 21 percent, the population increased 10 percent per year from 1966 to 1970. Young hogs made up nearly balf and yearlings made up nearly a quarter of the fall population in 1969 . The proposed management program aims to economically control feral hog populations on private lands by paid recreational hunting, thus providing income for the landowner and recreation for the public.

\section{THE AUTHOR:}

Reginald H. Barrett is Assistant Professor of Forestry and Resource Management, Department of Forestry and Resource Management, Berkeley. 


\section{The Feral Hog at Dye Creek Ranch, California ${ }^{1}$}

\section{INTRODUCTION}

MAN HAS KNOWN the pig Sus scrofa as a domestic animal for 8,000 to 9,000 years (Sillar and Meyler, 1961; Zeuner, 1963; Bokonyi, 1970; Epstein, 1971; Protsch and Berger, 1973). Today it provides a major source of animal protein for mankind, and pork is second only to beef in pounds consumed per capita in the United States (Ensminger, 1961:24). The use of miniature swine for biomedical research is increasing (Mount and Ingram, 1971), and pig physiology continues to be studied in great detail (Braude, 1972). In contrast, the wild pig has received little attention. Most works are oriented towards the sportsman (e.g., Wardrop, 1914; Snethlage, 1967), although major ecological studies of the European wild boar have been made in Germany (Oloff, 1951; Briedermann, 1973), Russia (Sludskii, 1956; Bromlei, 1964), and Poland (Haber, 1969).

Native races of Sus scrofa that have no history as domesticated animals will subsequently be termed "wild boar." Wild boar will be distinguished from the "feral hog" which has been defined by McKnight (1964:3) as "... one that was once domesticated, or with domesticated ancestors, but now living as a wild creature. It is not under the effective ownership of humans and does not receive protection, care, or food as a deliberate gift from man."

Due to the pig's usefulness as a producer of meat and lard, it has been spread by man throughout the world.
This dissemination increased greatly during the age of exploration, when explorers, sailors, and settlers introduced swine into a multitude of new habitats. Pigs were first introduced to the United States in 1539 and subsequently spread throughout the Southeast (Towne and Wentworth, 1950). They presently occur in several parts of Anglo-America, including California (McKnight, 1964:42). Feral hogs have been in California since the arrival of the Spanish in 1769 and were released by the Russians at Fort Ross in Sonoma County, perhaps as early as 1812 (Hutchison, 1946:21). The greatest increase in their distribution throughout the state probably occurred during the homestead era, which continued from the Gold Rush in 1850 into the twentieth century.

By the 1840s, men such as Lassen,

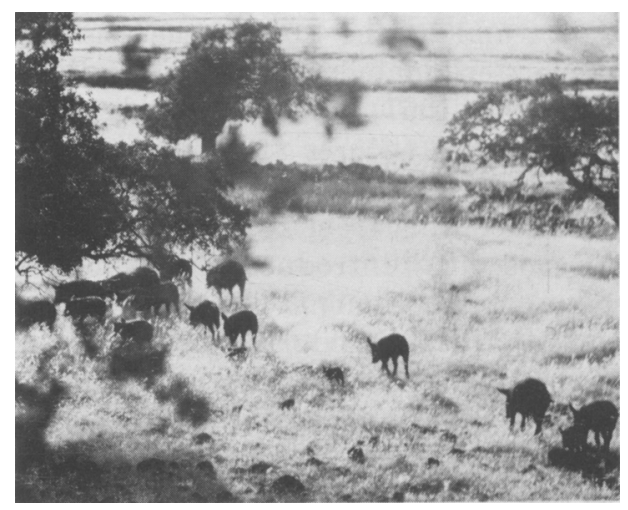

Feral hogs in eastern Tehama County stem from releases of domestic swine by homesteaders as early as 1880 .

2 This manuscript was accepted for publication May 31, 1978. 


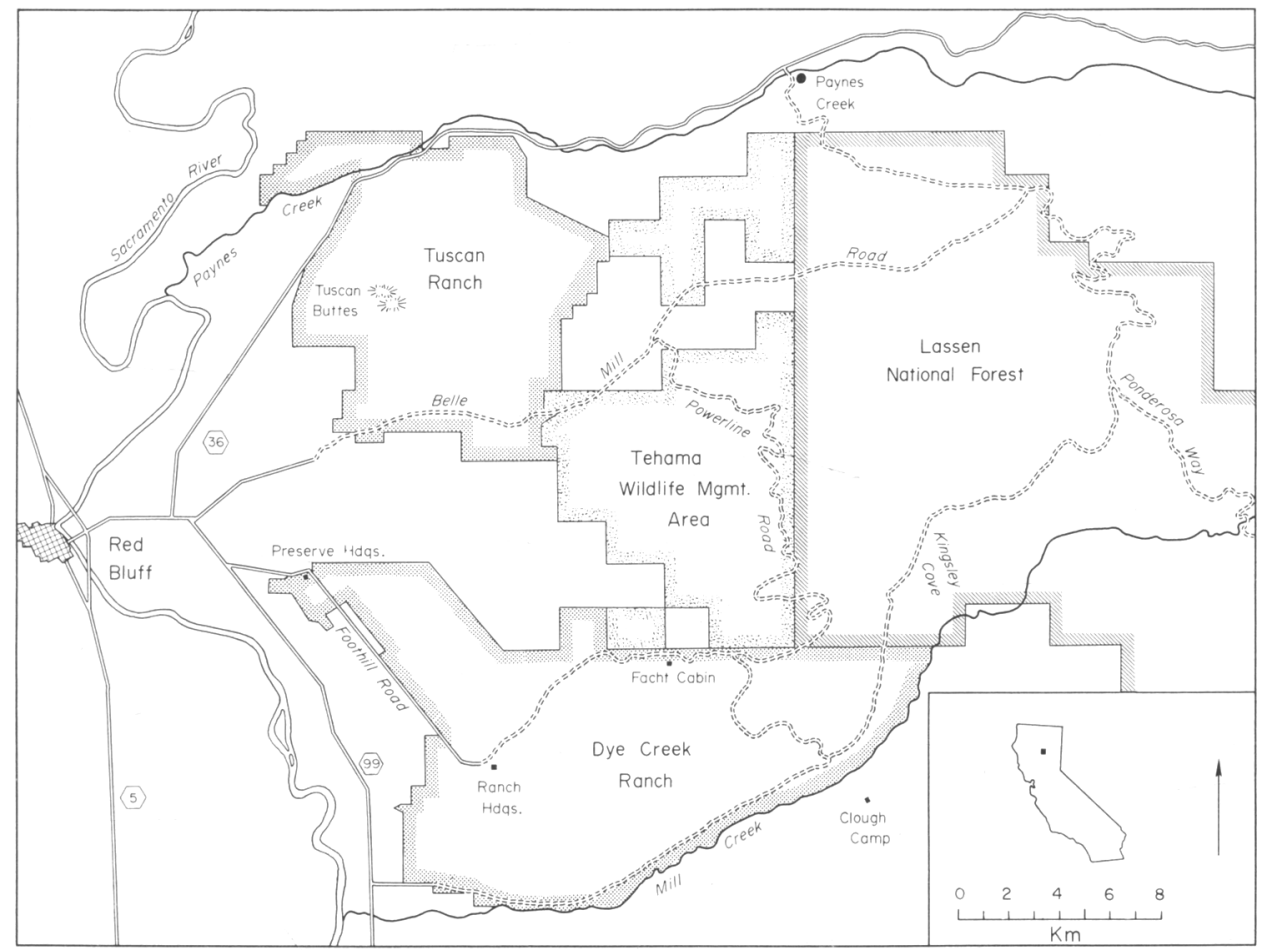

Fig. 1. Dye Creek Ranch study area.

Toomes, and Dye established rancheros along the Sacramento River in Tehama County and introduced domestic swine and other livestock. Settlers were hunting feral hogs in the foothills northeast of Red Bluff in the 1880s (Leslie, 1966), and by the turn of the century had exterminated the Yahi Indians (Kroeber, 1967) and the grizzly bear Ursus arctos (Storer and Tevis, 1955). This facilitated intensive homesteading of the foothills from 1890 to 1920 with the consequent introduction of domestic swine (pers. comm. with Mrs. Ward and Mr. A. H. Clough of Los Molinos, 22 January 1970). Swine were an important source of lard for the homesteaders who generally released their pigs to fatten during the acorn season (E. B. Shaw, 1940:245). Apparently, the feral hog has taken advantage of the niches vacated by the bears and the Indians.

During the 1920s most of the homesteaders moved from the area, and cow- hands, a few old-timers, and hunters were the only people entering the roadless foothills. Ranch employees and local citizens, hunting with dogs, kept the feral hog population under control along the valley edge. In 1963, William Keeler purchased the Dye Creek Ranch (Fig. 1) and instigated a policy of multiple land use. In addition to continuing a cattle operation, he set up a commercial hunting preserve. Hunting pressure by local people was removed but partially replaced by the Preserve's first boar season in the winter of 1966-1967.

European wild boar have twice been introduced into North America as a sporting animal (Manville, 1964). In 1911, 13 young European wild boar were shipped from Germany to Hooper's Bald, North Carolina, where their descendants interbred with feral hogs already in the region (Jones, 1959). Some of these descendants were introduced into Monterey County, California in 1923. The wild boar eventually 
spread south through the Santa Lucia mountains and interbred with the existing feral hogs (Blocker, 1937; A. C. Shaw, 1940; Bruce, 1941). Wild boar from Monterey County have now been transplanted to several areas of California including Tehama County. Despite this, the feral hog is still the predominant type of wild pig found over most of the state, including the Dye Creek Ranch.

Several studies have been made of the wild boar in America (Stegeman, 1938; Bruce, 1941; Matschke, 1962, 1963, 1964, 1967; Henry, 1968, 1969, 1970; Pine and Gerdes, 1973), but little work has been done on the feral hog (Hanson and Karstad, 1959; Sweeney,
1970; Wood, 1977). The present study was undertaken to obtain ecological information for use in the management of the feral hog on the Dye Creek Ranch. Particular effort was made to describe the manner in which this large, exotic mammal has adapted to the Dye Creek area. The most likely mechanism of natural population regulation appeared to be through the effect of the quantity and quality of available food on lactation and piglet survival. A comparative study was planned to investigate this hypothesis. The field work was carried out from June, 1967, to September, 1967, and continued from June, 1968, to January, 1970.

\section{METHODS}

The major activities conducted throughout the study were analysis of vegetation, field observation, capturing and marking of hogs, and collecting and autopsy. Other methods used will be described in the appropriate sections. Nomenclature used follows Miller and Kellogg (1955) for mammals and Munz and Keck (1959) for plants.

\section{Analysis of vegetation}

A collection of 322 plant species was made and housed in a herbarium at the Dye Creek Field Station. After preliminary study of aerial photos and on-theground reconnaissance, the vegetation was subjectively divided into eight types. The botanical composition of each type was sampled using six, ramdomly located, 100-point transects in each vegetation type as outlined on aerial photos. At each step-point (taken every other pace), the nearest herb within $15 \mathrm{~cm}$, the nearest shrub within $2 \mathrm{~m}$, and the nearest tree within $6 \mathrm{~m}$ were recorded. Density and canopy cover of woody vegetation was determined using acre (0.405 hectare) square sample plots set at random in each type within type lines drawn on the aerial photos. Herbaceous cover was determined from 100 points taken at random in each type with a 10-pin, point frame. This work was done in April, 1970, when most herbaceous species were flowering.

\section{Field observations}

Binoculars $(8 \times 40)$ were the standard equipment for field observations. Cards listing the tagged and otherwise identifiable hogs for each five subunits in the study area were continually updated as new individuals were observed. I recognized many untagged hogs simply by their coat-color pattern.

I recorded 1,824 separate observation periods in which a total of 14,707 hogs were tallied including repeated observation of many individuals. Approximately 500 hours were spent actually watching free-ranging feral hogs. Groups were observed for from less than one min. to more than 4 hours at a time, but most observations lasted less than $10 \mathrm{~min}$.

\section{Trapping}

Information on size, growth, and population structure was obtained by trapping. Captured hogs were marked, aged, measured, and released, often to 


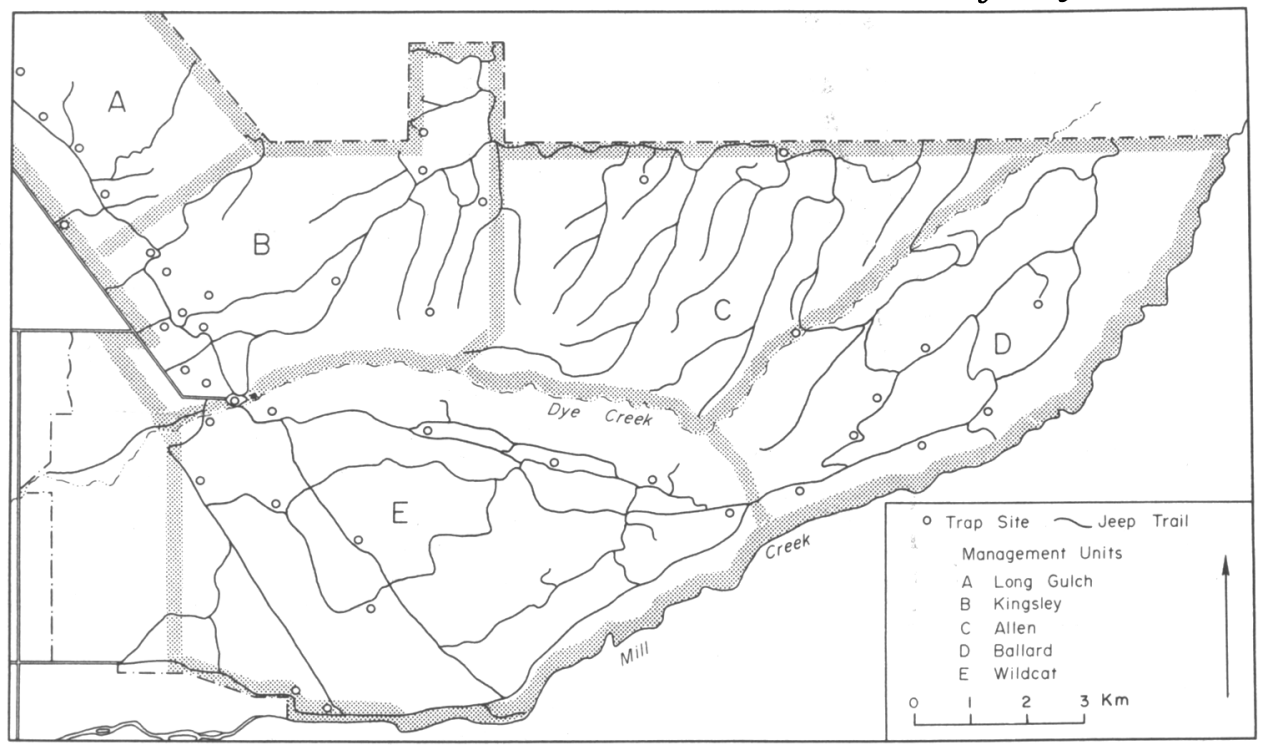

Fig. 2. Trap sites, jeep trails, and feral hog management units on the Dye Creek study area. Most of the field work, including the habitat analysis, was carried out in the Kingsley and Ballard units.

be recaptured. Three types of traps were used successfully: permanent corral traps (3), portable panel traps (5), and portable box traps (6). Drop doors proved, with all traps, to be more reliable than swinging doors (Barrett, 1971). The corral traps were most efficient where a large number of hogs congregated in one area, such as along a trail to an irrigated pasture. Due to the large size of these traps, it was difficult to rope and restrain a captive hog, and for most purposes the portable box traps were the most efficient.

Most trapping was done during the spring and summer. During the autumn it was particularly difficult to draw the hogs to bait, because acorns were abundant. Little trapping was done in the winter, and I joined hunting parties to collect samples. During the summer, the hogs came readily to many types of bait including barley, commercial pig feed, mill sweepings, molasses, peaches, and fish.

Once hogs discovered the bait they continued to return to the site as long as bait was left each night. Normally, $\mathrm{I}$ left 2 to 5 pounds of bait on hog trails and then placed traps in those locations where the bait was regularly taken. Prebaiting improved the trapping success greatly, because sometimes a week passed before hogs discovered the bait.

I moved the traps in a cyclic pattern from one area to another. Most of the hogs in the vicinity of a trap site were captured within a week of discovering the bait; thereafter most of the hogs caught were recaptures. A total effort of 790 trap nights was expended over 41 trap sites (Fig. 2). Of this total, 55 percent were successful in capturing at least one hog.

A total of 731 female and 694 male (including barrows, i.e., castrated boars), or a grand total of 1,425 captures were made. This figure includes 601 different individuals. The average number of recaptures was 2.3 for males and 2.4 for females; the difference being insignificant $(P<0.1)$. In addition to those trapped, another 48 animals were tagged after capture with dogs or release from the Dye Creek breeding pens.

Young hogs, particularly young males, tended to be captured more often 
than adult hogs, particularly older boars. Old boars often attempted to reach the bait by tipping the traps over rather than entering them. Any population structure estimates based solely on trapping data would tend to overestimate the number of young and underestimate the number of adult boars.

\section{Drugging}

A few hogs were captured with $\mathrm{Su}$ costrin (succinylcholine chloride injection U.S.P., E. R. Squibb \& Sons, New York) using a Palmer, $\mathrm{CO}_{2}$-powered Cap-Chur gun. This technique was not as efficient as trapping, however, and was discontinued.

Trapped hogs over 150 pounds (68 $\mathrm{kg}$ ) were immobilized with Sucostrin which acted rapidly and lasted just long enough for the necessary work to be done. This technique was safer and more efficient than tying the animal down with ropes or a net. Henry and Matschke (1968) used Cap-Chur-Barb (pentobarbital scopolamine), but this drug took approximately $55 \mathrm{~min}$. to immobilize the animal and lasted an average of three hours.

There are two problems with succinylcholine chloride (Harthoorn 1965: 43): (1) in the liquid form it must be refrigerated, and (2) the dosage is relatively critical, although less so for pigs than for most other ungulates. Selecting the proper dose did not prove a problem since I was able to make reasonably accurate weight estimates for hogs in a trap. The $100 \mathrm{mg} / \mathrm{cc}$ solution was injected into the ham of the hog with a 1-ce hypodermic syringe while the hog's head was tied to the side of the trap. The animal was untied as soon as the drug was injected.

Out of 141 attempts to immobilize hogs in traps, five animals $(3.5 \%)$ died from overdoses, two at the beginning of the work and three during the study. Two of the three were littermates and succumbed to normal dosages, suggest- ing genetic variation in response to this drug.

Fifteen of the drugging attempts required one or more additional doses when I underestimated the weight of the animals or accidentally injected the drug into the fat layer instead of the muscle. Where a second dose was required the animals soon built up a resistance to the drug and required a greater dosage each time a subsequent one was given. However, if a second dose was given within a few minutes of the first, the effect of the second dose was additive. I usually administered only $10 \mathrm{mg}$ no sooner than $2 \mathrm{~min}$. after the previous dose. Rarely more than three consecutive additional doses were required.

A single injection was successful with 121 hogs $(86 \%)$. Boars generally required slightly higher dosages than sows, and boars in good condition required a higher dosage than boars in poor condition. Condition of the sow was also of some importance, but this was complicated by the effects of pregnancy. Pregnant (90+ days) sows required a lower dosage than nonpregnant sows. The average successful dosage ranged from $0.37 \mathrm{mg} / \mathrm{kg}$ for a weak reaction by pregnant sows to 0.70 $\mathrm{mg} / \mathrm{kg}$ for a strong reaction by boars in good condition. The overall range of successful dosages was $0.30 \mathrm{mg} / \mathrm{kg}$ to $0.88 \mathrm{mg} / \mathrm{kg}$ which falls within the range of successful dosages given by Zurowski and Sakowicz (1965) for European wild boar.

\section{Handling and marking}

Hogs up to 150 pounds ( $68 \mathrm{~kg}$ ) were hung by their heels from a spring scale by means of rope hobbles attached to their hind legs just above the hocks. Larger hogs were immobilized with drugs and examined while lying on the ground. When in the hanging position, the animals could be safely weighed to the nearest pound, aged, and measured in a few minutes. Age determination 
was accomplished with a mouth speculum, using the techniques described below. Seven standard body measurements (Ansell, 1965) were taken including: total length (over the curves), head length, tail length (angle $40^{\circ}$ ), shoulder height (between pegs), heart girth, ear notch length, and hock length (over hoof, normal position). Measurements were made with a steel tape. Total length was measured to the nearest inch $(25.4 \mathrm{~mm})$ on adults. Shoulder height and heart girth were measured to the nearest half-inch $(12.7 \mathrm{~mm})$, and the remaining parameters were measured to the nearest quarter-inch (6.4 $\mathrm{mm})$.

Record cards were kept for each animal. Weights were taken each time an animal was captured, but other measures were taken no more often than monthly. Data on movements, condition, abnormalities, parasites, reproductive state, and a general description of each animal were recorded.

Early attempts to brand the hogs on the inner hind leg were unsuccessful. The Jumbo Rototag (NASCO, Fort Atkinson, Wisconsin) proved to be the most successful ear tag. They were visible up to a quarter-mile $(0.4 \mathrm{~km})$ away under excellent conditions with a spotting scope, and lasted up to 2 years. A hole left in the ear identified an individual as having lost a tag, which rarely occurred. By checking records on sex, age, color, teat number, and the location, I could always identify such individuals.

Some sows were marked with plastic streamers (150 mm long) which were visible up to a half-mile $(0.8 \mathrm{~km})$ away. The streamers were inserted through a slit in the lower edge of the ear. Streamers usually were lost within 6 months but some remained for over a year. Boars lost streamers rapidly due to their continual fighting.

Other useful marks were cut ears, cut tails, or castration. These marks were made by the Ranch cowboys when they occasionally caught hogs. With the combination of 11 basic coat color patterns, 10 streamer colors, five Rototag colors, and the possibility of marks in either ear, I had little trouble identifying individual hogs within $100 \mathrm{~m}$.

\section{Age determination}

Several methods have been used to determine the age of wild pigs. Sportsmen often consider the size of the animal and its tusks (Kiessling, 1925; Snethlage, 1967), but there is great variation in these characters. Matschke (1963) and Sweeney et al. (1971) found eyelens weight to be of less value than tooth eruption pattern as an age indicator. Cabon (1959) concluded in her review that the most objective method involved the use of a tooth eruption schedule for pigs under 3 years old, and tooth wear for older pigs. No studies have considered the use of growth rings in the teeth of pigs. Such rings could be seen in a small sample of teeth from Dye Creek pigs.

Many schedules have been published for tooth eruption in domestic swine (Brown, 1895; Huidekoper, 1903; Morrison, 1928:28; Sisson and Grossman, 1938:488; Habermehl, 1961:115). A few publications give schedules for wild boar (Cabon, 1959; Habermehl, 1961: 181; Matschke, 1967), and Weaver et al., $(1966,1969)$ provided schedules for "miniature swine" derived from feral hogs. There is some variation between schedules for domestic swine and wild pigs, which may be largely due to differences in nutritional status. McCance et al. (1961) found that poor nutrition retarded tooth eruption in pigs, although not as much as it affected body size. Pine and Gerdes (1973) found the tooth eruption schedule developed by Matschke (1967) gave satisfactory results with wild pigs in Monterey County, California. I was able to follow the eruption pattern of a number of tagged piglets for up to 18 months. In all cases, their true age fell within 
the limits suggested by Matschke's schedule, although the few data available suggest a slightly earlier average eruption date for the Dye Creek feral hogs.

Based on Matschke's (1967) schedule, I estimated the age of each hog captured to the nearest month up to 26 months with a probable accuracy of \pm 1 month. Individuals with the third molars 75 to 95 percent erupted but not worn were placed in the 30 -month group. At 36 months, the permanent dentition is complete, and beyond 3 years, age determination is less reliable.

I based my classification of older age groups on skulls from two animals of known age and on descriptions of molar wear given by Cabon (1959). The hogs of known age (4 and 6-7 years old) were marked when young by Ranch employees. Also, two individuals classed as 3-year-olds in 1967 were reexamined in 1969 when 5 years old. The age groups beyond 36 months were distinguished in the following manner on the basis of wear of the third molars: 48 months, height of molar cusps reduced 25 to 50 percent; 60 months, cusps 60 to 90 percent worn; $72+$ months, cusps completely worn and first molars often lost.

\section{Autopsies}

Autopsies of 129 hogs were carried out in connection with the commercial hunting season on the Dye Creek Preserve from November to May. To the extent possible, I obtained body measurements, field-dressed weights, stomach samples, digestive fluid samples, female reproductive tracts, and skulls. Information on body fat stores, parasites and disease was also obtained from autopsies. I collected an additional 21 samples at other seasons.

\section{THE STUDY AREA}

The Dye Creek Ranch is at the northeast end of the Sacramento Valley, about $21 \mathrm{~km}$ southeast of Red Bluff, Tehama County, California (Fig. 1). The study was conducted on a 13,000hectare section of the Ranch, extending from the valley floor into the Sierra foothills. The area is bounded on the north by the Tehama State Wildlife Management Area, on the east by the Lassen National Forest, and on the south and west by other private lands.

The elevation of the study area increases from $76 \mathrm{~m}$ on the Sacramento Valley floor to $762 \mathrm{~m}$ elevation in the foothills. There is an abrupt rise at the valley edge of about $300 \mathrm{~m}$, then the general level of the foothills rises gently eastward to the mountains. The foothills are cut by small to medium-sized streams that follow steep, rugged canyons westward to the Sacramento Valley where they join the Sacramento River.

The east-to-west flow of the streams causes most slopes to have either a north or south aspect. These slopes are generally quite rocky, with bedrock outcrops and numerous boulders lying over the landscape. The horizontal stratification of the bedrock results in broken slopes with many cliffs and benches.

\section{Geology and soils}

The study area lies at the southwestern edge of the Cascade Range Province (Bailey, 1966:68). The Tuscan formation is the major geologic formation underlying the area. This large, westward-dipping formation is composed primarily of volcanic tuff-breccias (Anderson, 1933; Rogers, 1962; Burnett, 1963).

The soils of the study area can be divided into two broad groups: (1) soils of the foothills, and (2) soils of the floodplains and terraces in the Sacramento Valley (U.S. Department of Agriculture, 1967). The foothills are covered by soils of the Toomes-Guenoc association. These are shallow to moderately deep, rocky soils underlain by 


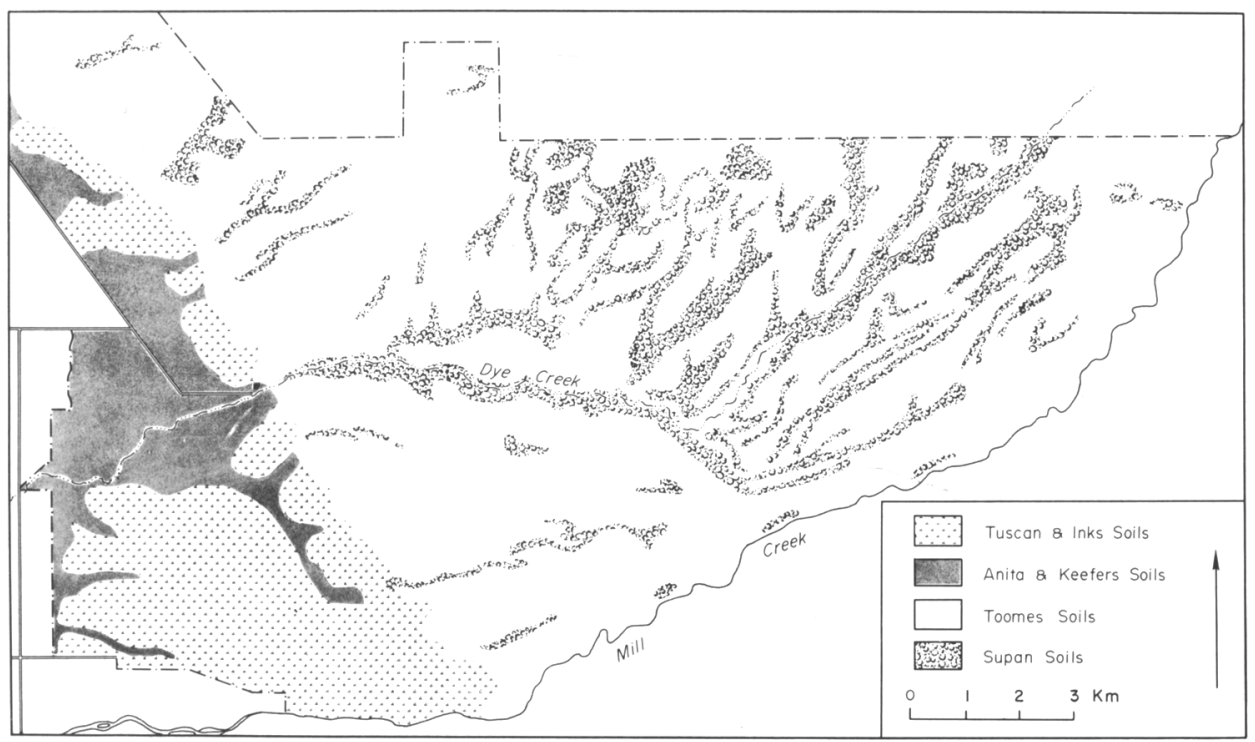

Fig. 3. Generalized soil vegetation map of the Dye Creek study area. Adapted from the Tehama County, California, Soil Survey, by the U.S. Department of Agriculture (1967).

volcanic rocks of the Tuscan formation. Shallow soils of the Toomes series cover most of the area. Deeper soils of the Supan series occur in relatively small, narrow strips throughout the foothills. The old alluvial terraces, which cover most of the valley land in the area, are overlain by soils of the Tuscan-Inks association. These cobbly soils are shallow to moderately deep above a hardpan. Deeper soils of the Anita and Keefers series cover the majority of the plains north of Dye Creek and support irrigated pastures. Distribution of soils over the study area is shown in Fig. 3 .

\section{Climate}

Eastern Tehama County has hot, dry summers and cool, wet winters typical of a Mediterranean climate (Elford and McDonough, 1964). January temperatures average $7^{\circ} \mathrm{C}$ but the foothills are generally a few degrees cooler. There are normally 23 days per year with minimum temperatures below freezing at Red Bluff. July temperatures average $27^{\circ} \mathrm{C}$ in the valley but are generally a little cooler in the foothills. Maxima of over $32^{\circ}$ occur an average of 97 days per year at Red Bluff. Occa- sionally temperatures reach $46^{\circ} \mathrm{C}$ in the summer (E.S.S.A., 1969).

Average yearly precipitation totals on the study area run from $58.4 \mathrm{~cm}$ in the valley to $76.2 \mathrm{~cm}$ in the higher foothills. The average for most of the lower foothills is probably $63 \mathrm{~cm}$. Very little rain falls during the summer; 90 percent of the yearly total falls in the seven winter months from October through April. There is great annual variation in precipitation pattern. In dry years, totals for the valley drop as low as $25.4 \mathrm{~cm}$; whereas, in wet years as much as $203 \mathrm{~cm}$ may fall in one winter. Precipitation was above average in two of the three study years, the 1967-1968 season being a dry one. Snow rarely falls at the lower elevations; however, during the winters of 1967-1968 and 1968-1969 significant amounts fell even in the valley and remained on the ground up to 3 days. Usually, snow does not play an important part in the ecology of the area (E.S.S.A., 1969).

The seasonal pattern of precipitation and evapotranspiration was calculated from mean monthly temperatures by Thornthwaite's (1948) method (Fig. 4 ). Given a seasonal precipitation of 
$58.4 \mathrm{~cm}$ and seasonal evapotranspiration of $91 \mathrm{~cm}$, the calculated winter water surplus is $33 \mathrm{~cm}$, and summer water deficiency is $63.5 \mathrm{~cm}$-assuming a figure of $10 \mathrm{~cm}$ for the amount of soilmoisture utilization and recharge.

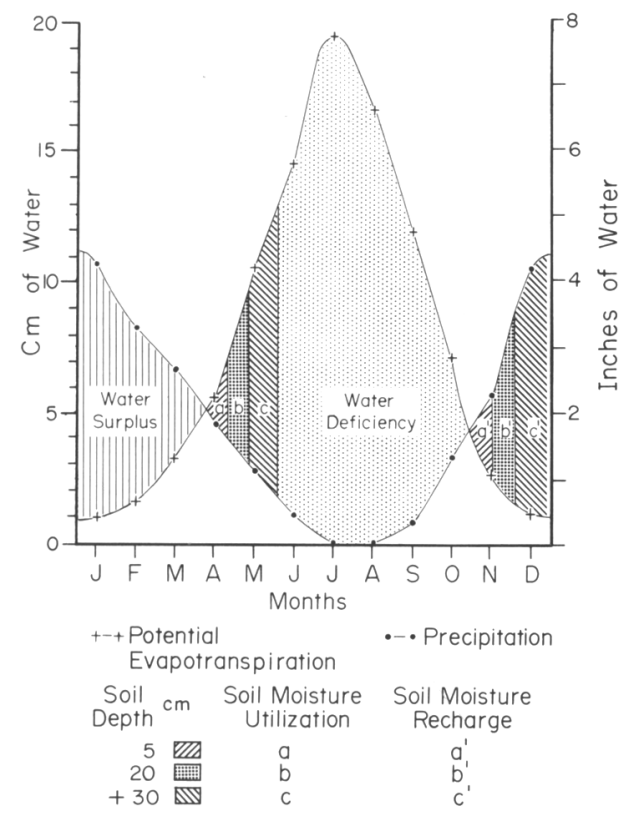

Fig. 4. Seasonal change in precipitation and evapotranspiration, describing the soil moisture regime for Red Bluff, California, calculated by the method of Thornthwaite (1948). The moisture depletion dates for 2- and 8-inch (50 and $200 \mathrm{~mm}$ ) soils are estimates.

\section{Hydrology and water resources}

The majority of the soils in the study area are very shallow, and the thinnest are dry as early as May. Thus, the annual vegetation dies about a month earlier than in most of the other foothill regions around California. The preponderance of thin soils on an impermeable substratum results in rapid runoff from the watersheds during the winter rains. Flooding is common along all of the streams. The first runoff of the winter carries with it considerable quantities of silt, especially when the first storm is severe.

All but the major streams are shortlived, and even these have very low flows in the late summer. Although run- ning water does not last long, potholes in the volcanic bedrock may hold pools of water late into the dry season. Springs and seeps are common throughout the foothills. They drain from the less consolidated substrata, and several may be located along certain contours. Most of these springs dry up in the summer. Many have been improved recently, and now empty into stock ponds or sumps.

Twenty-seven small stock ponds and a greater number of small sumps have recently been constructed in the foothills. The sumps hold water for only a few weeks after a rain, but at least seven of the stock ponds contain water throughout the year. More than 20 shallow duck ponds have been constructed on the valley plains. Most of these dry up in the summer. An irrigation canal built in the 1920 s brings water yearround from Mill Creek, north along the base of the foothills for the entire length of the study area. This canal is a vital water source for the valley region during the summer, sustaining irrigated pastures and providing high quality drinking water.

During the winter, good quality water is available in every low spot and small drainage. As summer progresses, water becomes restricted to the few perennial streams, potholes, springs, stock ponds, and the canal. However, even at the end of the dry season there is some source of free water in nearly every square kilometer of the foothill region.

\section{Vegetation}

According to Holdridge's (1967) classification of world plant formations, the study area would fall into the category of a "Dry Forest," with a biotemperature of $17^{\circ} \mathrm{C}$ and a mean annual precipitation of $65 \mathrm{~cm}$. This description fits the general character of the vegetation. The area falls into Merriam's (1898) Upper Sonoran Life Zone, and it would be classified as a Digger PineOak Forest by the Society of American 
TABLE 1

TWO DIFFERENT CLASSIFICATIONS OF VEGETATION AT DYE CREEK RANCH, TEHAMA COUNTY, CALIFORNIA

\begin{tabular}{|c|c|}
\hline Present study & Jensen (1947) \\
\hline $\begin{array}{l}\text { Valley region: } \\
\text { Upland plain } \\
\text { Boulder wash } \\
\text { Irrigated pasture }\end{array}$ & $\begin{array}{l}\text { Nonforested land: } \\
\text { Grassland } \\
\text { Grassland } \\
\text { Cultivated }\end{array}$ \\
\hline $\begin{array}{c}\text { Foothill region: } \\
\text { Rock-grass } \\
\text { Buckbrush }\end{array}$ & $\begin{array}{l}\text { Grassland } \\
\text { Chaparral }\end{array}$ \\
\hline $\begin{array}{l}\text { Oak savanna } \\
\text { Oak woodland } \\
\text { Oak thicket }\end{array}$ & $\begin{array}{l}\text { Hardwoods: } \\
\text { Woodland grass } \\
\text { Blue oak woodland } \\
\text { Live oak woodland }\end{array}$ \\
\hline
\end{tabular}

Foresters' (1954) forest classification scheme. Digger pine Pinus sabiniana is uncommon in the area but does occur along Mill Creek.

I classified the vegetation of the study area into types which were well represented and easily distinguishable. Key plant species are the most distinctive attribute of each type. Table 1 gives a comparison of the classification used with that of Jensen (1947). Vegetation ranges from sparse annual grassland to dense foothill woodland (Table 2 ) depending primarily on the degree of soil development on the geologically young substrate, and to a lesser extent on the exposure and slope (Barrett, 1971).

The upland plain type covers most of the valley region of the study area. It is an annual grassland with variable species composition (Talbot, et al., 1939; Heady, 1956, 1958; Biswell, 1956; Burcham, 1957). It occurs on the poor terrace soils of the Tuscan and Inks series and on the deeper terrace soils of the Keefers series. The topography varies from flat to hummocky and the streams have cut shallow channels through the terraces.

On the shallower Tuscan soils, annual forbs such as alkali goldfields Baeria platycarpha and annual fescues Festuca spp. predominate. In the deeper soils of the Keefers series, filaree Erodium spp., bur clover Medicago hispida, and soft chess Bromus mollis predominate. On some of the best sites, slender wild oat Avena barbata and the native perennial grasses, purple needlegrass Stipa pulchra and pine bluegrass Poa scabrella are found. Summer-maturing species such as camphor weed Trichostema lanceolatum, rosin weed Calycadenia fremontii, yellow star thistle Centaurea solstitialis, and Lessingia nana set the aspect of the upland plain type during the dry season.

Annual grassland-perennial grassland prior to European settlement (Burcham, 1957; Heady, 1977) -is now the climax vegetation throughout the main portion of the valley region, largely because of shallow soils, a hardpan, and less annual precipitation than in the foothills. However, it is likely that valley oak woodland is the climax vegetation on the alluvial soils along the major streams. Throughout the Sacramento Valley most of the original valley oak woodland has been cleared for agriculture.

Normally, most vegetation is dry by the end of May, and seedling germination does not begin until the first rains in October. Plant growth is retarded through the winter by low temperatures but increases rapidly as the weather warms in the spring. Flowering and seed set occur from March to May for most species, but a few weedy species mature during the summer. The phe- 


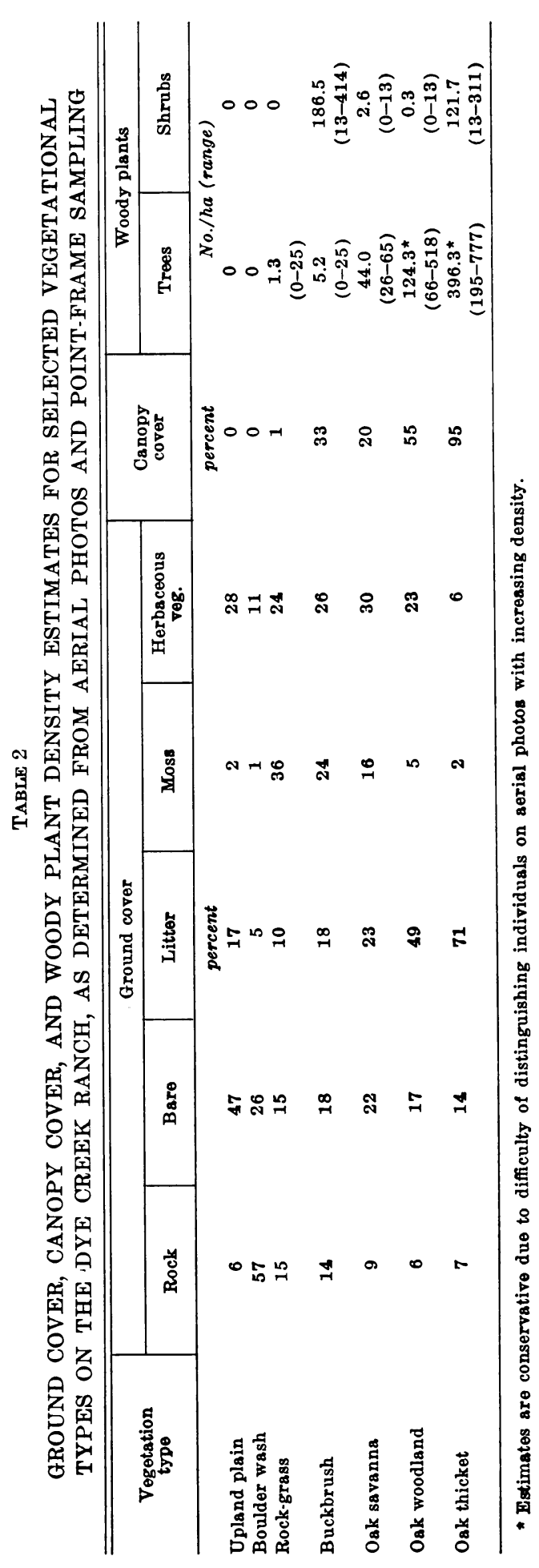

nology and composition of the annual grassland varies greatly from year to year with annual variation in weather. No major fires have occurred on the upland plain type for many years. Cattle use is relatively heavy for a short period in the spring, and most of the upland plain type is below optimum condition.

The boulder wash type consists of numerous low drainage channels and basins and makes up approximately 10 percent of the valley region. It is most extensive on the low-lying, heavy-textured Anita soils which remain moist longer into the dry season than the surrounding plains. An abundance of rounded cobbles and boulders lying on the surface characterize this type. Feral hogs root and overturn these rocks thereby keeping them on the surface. In areas not rooted, this type is more heavily vegetated, and the rocks are less conspicuous.

Dominant grasses are the early maturing Poa annua and the late maturing Hordeum hystrix. Bur clover and tomcat clover Trifolium tridentatum are the major nonbulb-producing forbs in this type. Several species of Brodiaea are the most common plants in the boulder wash type, and their bulbs are the food item sought by feral hogs. Bulbed species are well adapted to the heavy soils of this type and seem to be able to withstand heavy and frequent rooting. During the summer, turkey mullein Eremocarpus setigerus, milkweed Asclepias spp., and Eriogonum vimineum invade the washes where hogs have recently rooted.

The irrigated pasture type includes all of the valley region which is floodirrigated from June through September. It covers approximately 300 ha of the study area and includes some leveled and seeded pastures as well as wild pasture. These pastures occur mainly on Anita and Keefers soils. The fields just north of Dye Creek are not leveled and include low, marshy spots and 
small reservoirs. The major pasture grasses are perennials, including Dallas grass Paspalum dilatatum, Bermuda Grass Cynodon dactylon, and Johnson grass Sorghum halepense. White clover Trifolium repens and bur clover are the major forbs. On the higher and drier sites, many weedy species such as ribgrass Plantago lanciolata and low ragweed Ambrosia artemisiifolia are common; whereas, on the lower sites cattails Typha latifolia, spikerush Eleocharis sp., and willow weed Polygonum lapathifolium predominate. There are a few groves of cottonwoods Populus fremontii and willows Salix melanopsis, and scattered brambles of Himalaya berry Rubus procerus. The phenology of this type is almost the opposite of the annual grassland. The major species are dead or dormant during the winter. Growth and flowering occur during the summer with the onset of irrigation. Cattle grazing is normally heavy throughout the year, and supplemental feed is provided during the winter.

The rock-grass type occurs in the foothills on the shallower Toomes soils and is surpassed in area only by the oak savanna type. Rock-grass is most common on ridge tops and south slopes, but also occurs in lengthy strips along the contour of the canyons where the more resistant tuff-breccias outcrop. This type is most easily distinguished by the abundance of surface rock and moss, and by the presence of alkali goldfields and annual fescues. The rockgrass type grades, with increasing soil depth, from bare rockland to buckbrush (Ceanothus cuneatus) or oak savanna.

The buckbrush type is relatively uncommon in the lower foothills but becomes more extensive and grades into a more complex chaparral at higher elevations east of the study area. It occurs most often on the deeper, relatively coarse-textured Toomes soils and may be found on any topography, but it is most common on ridge tops. Buckbrush is the dominant woody species, but normally a few blue oaks Quercus douglasii are present. The herbaceous layer is similar to that of the rock-grass type but has a greater percentage of annual grasses. Plantago hookeriana replaces alkali goldfields as the major forb species in this type. Buckbrush is crowded out by oaks on the better, heavier soils; therefore, on the light-textured soils the buckbrush type represents a successional step between the rock-grass and oak woodland types (Biswell and Gillman, 1961). Almost all of the buckbrush in the study area is mature or decadent, and judging from annual ring counts, most stands are well over 25 years old. No major fires have occurred on the ranch for at least this period. Most of the foliage is unavailable to black-tailed deer Odocoileus hemionus columbianus, and the remainder is heavily hedged. Few seedlings are present in the area, and this type seems to be slowly diminishing.

The oak savanna type is the most extensive type in the foothill region and gives the area the aspect of Holdridge's "Dry Forest." This type occurs on the deeper Toomes soils, or in areas where fracture traces are common in the bedrock. It occurs on all types of topography and even extends into the valley region for some distance, particularly along creeks. Blue oak is essentially the only tree species on this type and reaches a density of 65 trees per hectare. Buckbrush occurs in the type, to a minor extent, as the only shrub cover. The herbaceous layer of the oak savanna type is similar to that of the rock-grass and buckbrush types, but has a greater abundance of grass. Soft chess is the dominant herb. Filaree, bur clover, and native clovers Trifolium spp. are the major forbs. In terms of herbaceous forage, the oak savanna is the most productive of the foothill types.

The blue oaks are deciduous from November to March. Flowering occurs about April, and acorn drop begins the 
following September, production being quite variable. The oak savanna type represents a developmental stage between the rock-grass and the oak woodland types. It is close to, and often intergrades with, the buckbrush type but tends to favor the more finely textured, deep Toomes soils. Blue oak regeneration is not common but appears to be sufficient to replace those trees which are decadent and dying. Most trees are between 75 and 150 years old according to ring counts.

The oak woodland type is the third most extensive vegetational type in the foothill region. It occurs on all types of topography but is most prevalent on north-facing slopes. Oak woodland is found on the shallower phases of the Supan series that generally lie in long, narrow bands along the contour of the landscape. Blue oak is the dominant tree, and it forms a relatively dense stand with from 66 to 200 trees per hectare (White, 1966). Some scattered interior live oaks Quercus wislizenii occur in this type, along with an occasional buckeye Aesculus californica. Large, mature manzanita trees Arctostaphylos manzanita may be present as single individuals or in small groups. Most of these are slowly being crowded out by blue oaks. Shrubs, including buckbrush, redberry Rhamnus crocea, and the vinelike chaparral honeysuckle Lonicera interrupta, occur infrequently in this type. The herb layer of the oak woodland differs from the oak savanna in having fewer annual grasses (soft chess is still the dominant grass species), and more shade-loving forbs. The dominant herb Geranium pusillum gives the herbaceous layer a distinctive aspect in the springtime. Oak woodland represents a developmental stage between the oak savanna and the oak thicket types, and in many places it grades into these types. The blue oak stand probably is stable, except in a few sites where firewood is being cut.

The oak thicket type occurs on the deeper Supan soils. It is found to some extent on all topography but is most common and well developed on the lower north slopes, where a more moist microclimate prevails. The oak thicket is the most highly developed vegetative community in the area, and its botanical composition is more varied and more complex than any other type. Although interior live oak and California laurel Umbellularia californica are the dominant trees on most sites, scrub oak Quercus dumosa does occur as a major species on some sites, particularly south-facing slopes. The oak thicket has the densest tree and shrub layers and the sparsest herb layer of the foothill types. Because of the evergreen canopy, all the major understory species are shade tolerant. Poison oak Rhus diversiloba is the dominant shrub species, and the forbs Torilis nodosa and bedstraw Gallium parisiense are the most comon species in the herb layer. However, leaf litter is the most common ground cover.

The "riparian woodland" community was included in the oak thicket type because of its rarity. It is dominanted by interior live oak, valley oak Quercus lobata, sycamore Platanus racemosa, and alder Alnus rhombifolia. Wild grape Vitis californica and California blackberry Rubus vitifolius are two important understory species. This riparian subtype occurs only along the recent alluvial deposits of the larger streams and could be considered an extension of the valley oak woodland from the Sacramento Valley. Although it is quite small in extent, the riparian woodland subtype is highly preferred by the feral hogs, especially during the summer.

The live oaks flower about 2 weeks later than the blue oaks, and the acorns do not mature until the second autumn after pollination. Normally, live oak acorns fall in November, a month or more later than those of the blue oak. This difference is beneficial for wildlife, 
because it results in a longer and less variable acorn supply (Christisen and Korschgen, 1955; Reid and Goodrum, 1957). The present stands of live oak appear to be stable or slowly increasing, even though deer heavily browse all of the palatable species, including the live oaks.

\section{THE ANIMAL}

\section{Taxonomy}

The wild pig population on the study area consisted entirely of feral hogs until 1968, when the landowner began brceding captured feral sows with European type boars from Monterey County. By January, 1970, over 20 feral sows had been bred and released into the population. At that time I could account for at least 40 and possibly 60 "hybrid" young, an average of two to three per breeding. Except where noted otherwise, all the following lifehistory information pertains to the feral hog and not necessarily to the wild boar or hybrids. Brief comparisons are made with the wild boar since it is now present in the population.

The taxonomy and evolution of domestic swine has been heavily debated, particularly with respect to the ancestry of western domestic breeds (Nathusius, 1864; Rolleston, 1877; Nehring, 1888; Pira, 1909; Kelm, 1938). Because they readily interbreed, domestic swine and wild boar are presently considered to be the same species (Sus scrofa).

Simpson (1945) and Thenius (1970) have summarized the evolution of the Suidae, and Belic (1938) and Kelm (1939) have provided the latest reviews of Sus taxonomy. Haltenorth (1963:24) listed 32 subspecies for Sus scrofa. The majority of the European and North American breeds of domestic swine were developed from Sus scrofa scrofa in several locations and at several times, beginning in the Neolithic period over 6,000 years ago (Zeuner, 1963). The Asian breeds evidently were developed from Asian wild boar in a similar manner. Certain Asian breeds were imported into England between 1750 and
1800 and crossed with local breeds (Peirson and Owtram, 1945). Asian breeds were used to modify some of the modern American breeds during the late 1800s (Ensminger, 1961).

Most of the swine in California before 1900 were not purebreds; they were mongrels of various colors. These pigs were descendants of northern and southern European swine brought in by Spanish missionaries and settlers. At that time, the swine industry's most important product was lard; consequently, the short, chuffy, lard pig was the preferred type. This was undoubtedly the type released in the study area around the turn of the century. .

\section{Chromosomes}

McFee and his co-workers (1966) confirmed that domestic swine have a normal chromosome number of $2 \mathrm{n}=38$, but they also reported a normal karyotype of 36 chromosomes for the European wild boar in Tennessee. Hybrids between wild boar and domestic swine had 37 chromosomes, and members of the $F_{2}$ generation had 36,37 , or 38 . They suggested that these differences do not indicate differences in total chromosomal material, but represented a Robertsonian type polymorphism. Most likely a centric split of a pair of submetacentric chromosomes, producing two pairs of telocentrics, has caused the 38-chromosome condition in the domestic pig (Hsu and Mead, 1969). Rary et al. (1968) found a good correlation between the European wild boar "agouti" color pattern and a chromosome complement of 36 , and a spotted coat correlated well with 38 pairs. Although wild boar in Germany have 36 chromo- 
somes (Gropp et al., 1969), wild boar in Yugoslavia (Zivkovic et al., 1971), India (Manna and Talukdar, 1965), and Japan (Muramoto et al., 1965) have 38 pairs.

Based on the method outlined in McFee et al. (1965), peripheral leucocyte cultures from eight variously colored Dye Creek feral hogs showed these individuals to have a chromosome complement of 38 pairs (Barrett, 1971). The karyotypes were the same as those previously published for domestic pigs (e.g., Ruddle, 1964; Hulot, 1969).

Two European wild boars used for breeding feral sows were tested. These individuals were descendants of Monterey County wild pigs and had the typical conformation and color pattern of the wild boar type. Both boars had karyotypes of 36 chromosomes. One wild pig captured in Monterey County, and having the wild boar conformation, was found to have 38 chromosomes. Its coat color, however, was pure black with no agouti pattern. When bred to European sows which normally produced striped young, this boar fathered pure black offspring. Analysis of chromosome complements as well as coat color patterns and morphology should be useful in monitoring future changes in the percentage of European wild boar type in the Dye Creek population.

\section{Size and conformation}

The feral hog of eastern Tehama County is a descendant of the short, chuffy, lard hog described by Smith (1952) and well illustrated in Coburn (1922). It has relatively short legs and a round, barrel-like body when it is in good condition (Fig. 5), but when all fat is lost, it acquires a "razorback" appearance. It has a curly tail, upright ears, and a slightly dished face. This last characteristic is partially related to the level of nutrition during growth, inasmuch as individuals with better diets develop profiles more dished than

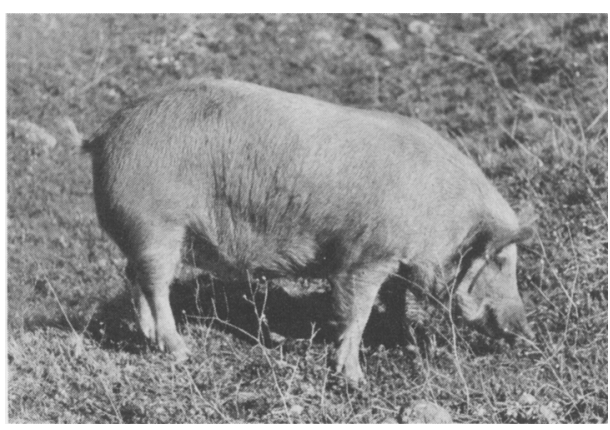

Fig. 5. A feral sow in excellent condition.

those of pigs with poor diets (Nathusius, 1864:99).

The distinguishing secondary sexual characteristics for the male feral hog are continuously growing canines or tusks, a larger head, and a heavy $3-\mathrm{cm}$ thick keratinous "shield" (Stemmer, 1909) covering the shoulder region. Castrated males (barrows) lose the shield and large shoulders of the boar but retain large tusks. Generally, barrows are larger in size than boars or sows.

The wild boar has longer legs, a deeper more laterally compressed body, higher shoulders, a longer snout, and a straighter tail than the feral hog (Stegeman, 1938).

The typical adult male hog on the study area weighed $80 \mathrm{~kg}$ live weight. The largest boar weighed was $125 \mathrm{~kg}$ and the largest barrow weighed was $157 \mathrm{~kg}$, but exceptional boars probably reach $170 \mathrm{~kg}$. A typical adult sow weighs about $75 \mathrm{~kg}$. The largest sow weighed was $170 \mathrm{~kg}$ but was extremely fat. There is a great deal of seasonal variation in the weight of individual animals, due mainly to the ability of the lard hog to deposit a thick subcutaneous layer of fat (Fig. 6). A sow in poor condition can nearly double its weight in a few months if sufficient acorns are available. Typical measurements for adult feral hogs in the study area are listed in Table 3; a detailed account of size is given in the section on growth. 


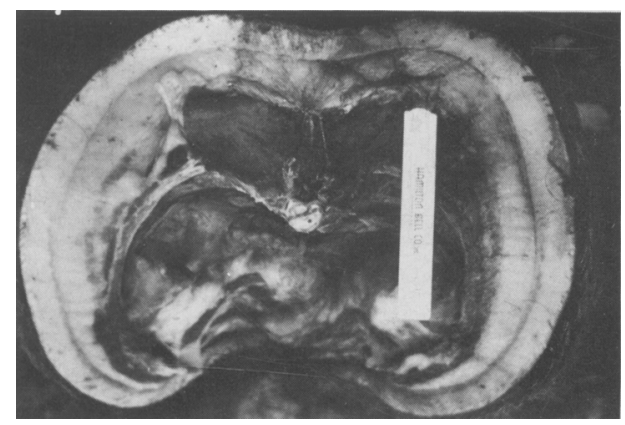

Fig. 6. Cross section through the carcass of a feral sow in excellent condition. The muscle is 2 inches $(50 \mathrm{~mm})$ deep and the fat is 3 inches $(75 \mathrm{~mm})$ deep (6-inch [152-mm] rule).

The few published records of average feral hog weights (Wodzicki, 1950: 239; Pullar, 1953) are similar to the figures for the Dye Creek hogs. European wild boar tend to weigh more and show greater sexual dimorphism than feral hogs (Boubier, 1929; Anon., 1949; Oloff, 1951; Sludskii, 1956; Kozlo, 1968; Haber, 1969; Briedermann, 1970; Henry, 1970; Pine and Gerdes, 1973).

\section{Skull characteristics}

A number of studies have provided quantitative descriptions of domestic swine and wild boar skulls (e.g., Rolleston, 1877; Major, 1883; Nehring, 1888; Miller, 1912; Matchie, 1918; Schroter, 1922; Bolkay, 1929; Adlerberg, 1930; Dehaut, 1939; Markov, 1954; Cabon, 1958b). However, most of these studies were based on very small samples, and none include data on feral hogs.
Thirty-nine different skull measurements were taken from each of 113 feral hog skulls collected on the study area. Details of measurements and their analysis are given by Barrett (1971). Growth curves for three skull parameters are given in Fig. 7. It takes 30 to 36 months for the maturation of most skull parameters, which correlates with the age at dental maturation. The upper canine alveolar breadth most clearly distinguishes the two sexes, barrows being similar to boars. For most characteristics, the Dye Creek skulls are intermediate between domestic swine and wild boar. The zygomatic breadthnasal length ratio was the most helpful characteristic in separating adult feral hog skulls from adult wild boar skulls; facial curvature was of little value (Barrett, 1971).

\section{Dentition and tusks}

The normal dentition for the feral hog is:

$$
2\left(\mathrm{I} \frac{3}{3} \mathrm{C} \frac{1}{1} \mathrm{P} \frac{4}{4} \mathrm{M} \frac{3}{3}\right)=44
$$

and has been described in detail by Virchow (1937), Sisson and Grossman (1938:485), Ripke (1964), and Landolt (1968). In some Dye Creek skulls the upper third incisors or lower first premolars apparently never erupted. Sowls and Phelps (1968) described a similar situation in the bushpig Potamochoerus porcus. I analyzed 100 complete feral hog skulls for the presence of these teeth; if a tooth appeared to have ever

TABLE 3

TYPICAL MEASUREMENTS (CM) OF ADULT FERAL HOGS IN EASTERN TEHAMA COUNTY, CALIFORNIA*

\begin{tabular}{|c|c|c|c|c|c|c|c|}
\hline Sex & $\begin{array}{r}\text { Total } \\
\text { length }\end{array}$ & $\begin{array}{l}\text { Head } \\
\text { length }\end{array}$ & $\begin{array}{c}\text { Tail } \\
\text { length }\end{array}$ & $\begin{array}{c}\text { Shoulder } \\
\text { height }\end{array}$ & $\begin{array}{l}\text { Heart } \\
\text { girth }\end{array}$ & $\underset{\text { length }}{\text { Ear }}$ & $\begin{array}{l}\text { Hock } \\
\text { length }\end{array}$ \\
\hline & \multicolumn{7}{|c|}{ centimeters } \\
\hline Boar & 170 & 34.4 & 30.5 & 67.3 & 99.1 & 15.7 & 27.9 \\
\hline \multirow[t]{2}{*}{ Sow } & 165 & 31.8 & 30.5 & 62.2 & 92.7 & 15.2 & 26.7 \\
\hline & \multicolumn{7}{|c|}{ percent } \\
\hline Difference & 3.1 & 8.0 & 0.0 & 8.2 & 6.8 & 3.3 & 4.8 \\
\hline
\end{tabular}

\footnotetext{
* Data are taken from growth curves presented in the discussion of growth (page 315).
} 


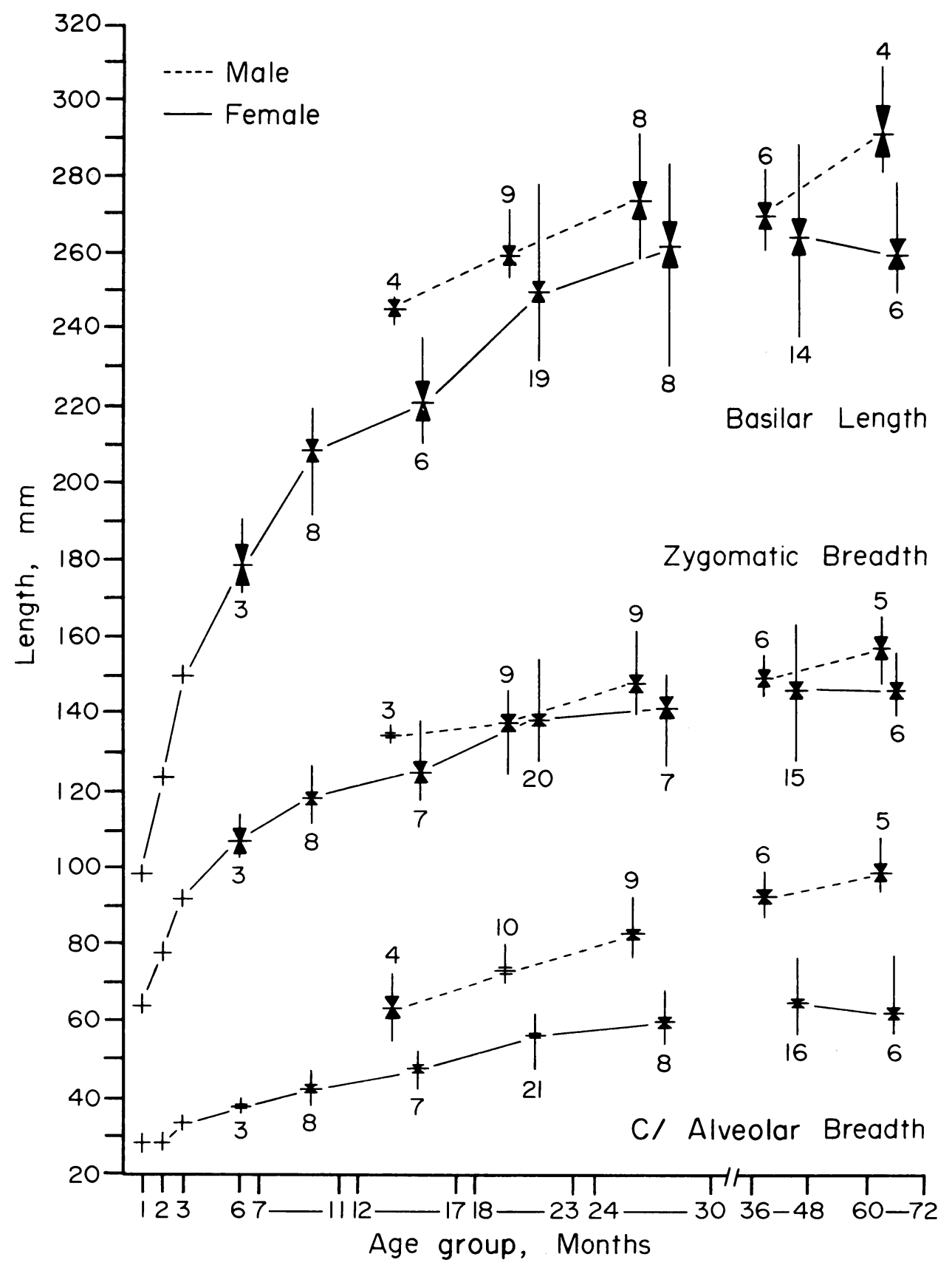

Fig. 7. Growth patterns for the basilar length, zygomatic breadth and upper canine alveolar breadth of male and female feral hog skulls. Horizontal bars represent the means, vertical bars represent the range, and triangles represent the standard error of the mean for each age group. Sample size is given above or below each range bar. 


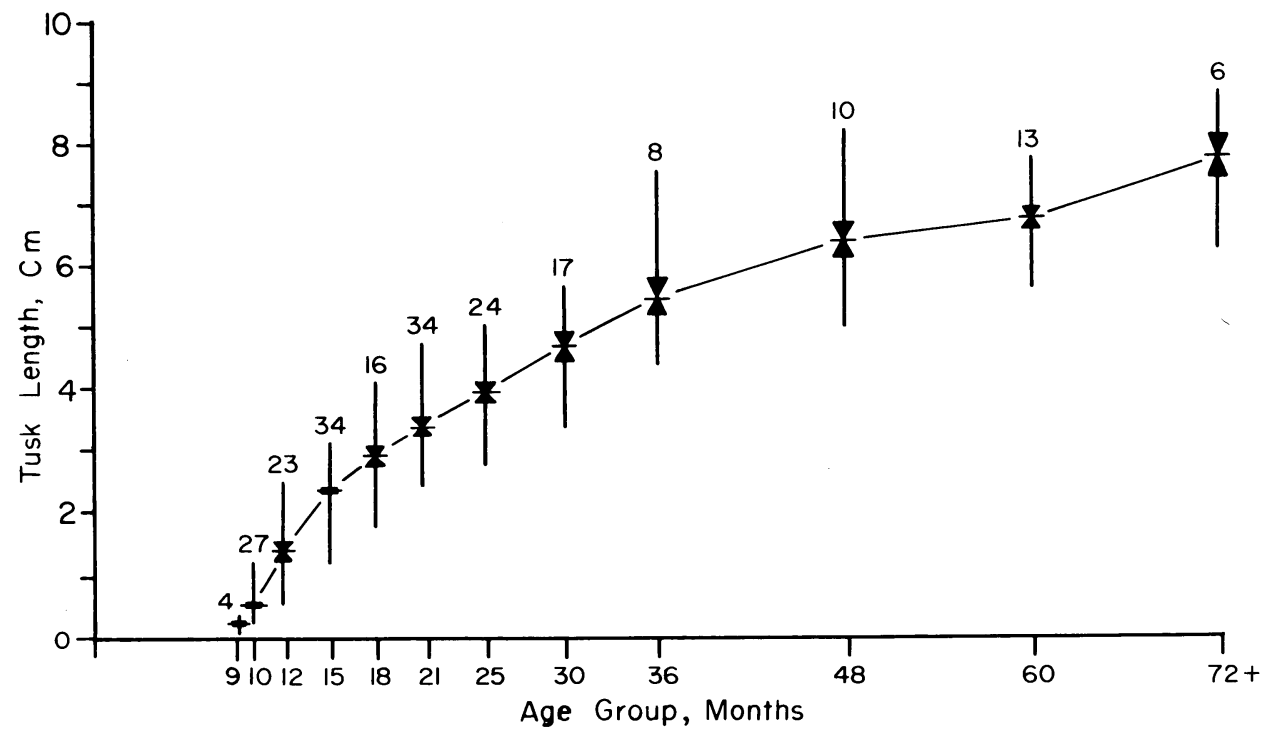

Fig. 8. Growth of the lower tusk in the male feral hog. Tusk length was measured from the gum line around the outer edge of the tusk to the tip. The means are indicated by a horizontal bar, the ranges are indicated by a vertical bar, and the standard error of the means is indicated by triangles.

been present it was counted as present. Normally if one incisor was missing, so was the other, and similarly for the premolars. Forty-five percent of the skulls were missing one to three of these teeth, and 6 percent had none. There was no significant difference between sexes.

Pullar (1953) and Snethlage (1967) gave good descriptions of the tusks of the feral hog and European wild boar, respectively. The lower tusks in the male attain a total length of up to 12.5 inches (318 mm) (France, 1969), but over half of this is buried in the mandible. The length of the lower tusk, measured along the outer curve from the gum line to the tip, is commonly used to determine the trophy value of a wild pig. Tusk lengths for a sample of 216 feral boars are presented in Fig. 8. From the ninth to the fifteenth month of age, the lower tusks grow from the gum line about $4.3 \mathrm{~mm}$ per month. After the lower tusks begin wearing on the uppers, the length from the gum increases only $1.5 \mathrm{~mm}$ per month. By 3 years of age a boar nor- mally has 5-cm tusks and can be classed as a trophy.

The maximum length from the gum measured in the sample was $89 \mathrm{~mm}$, but tusks of up to $100 \mathrm{~mm}$ have been recorded from Dye Creek boars. Occasionally, the upper tusks are broken off, allowing the lower tusks to grow unobstructed. In one such case the lower tusk measured $165 \mathrm{~mm}$ from the gum line, and if not broken off would have soon prevented the boar from feeding.

To determine absolute growth rate, I filed a small notch at the gum line in the lower tusks of 55 adult boars. Seventeen boars were recaptured and the new growth was measured to the nearest sixteenth-inch $(1.6 \mathrm{~mm})$. The average growth rate was $5.6 \mathrm{~mm}$ per month; therefore, approximately $4 \mathrm{~mm}$ per month, or over 70 percent of the lower tusk's growth is lost by abrasion with the upper tusk. The data did not indicate any variation in the rate of growth with age or with season.

There was considerable variation in the conformation of the tusks with respect to the angle at which the lower 
tusks wore against the uppers. In some cases the lower tusks were kept relatively short by arching directly into the uppers. At the other extreme, the lower tusks arched slightly ahead of the uppers and continued to grow beyond them. Thus, not only age, but conformation of the tusks is important in the production of an excellent trophy.

\section{Pelage and coat color}

The pelage of the Dye Creek feral hog is similar to that of domestic swine, having bristles but lacking an undercoat. On the adult, the bristles are 25 to $40 \mathrm{~mm}$ long, but they may reach 60 $\mathrm{mm}$ on the back between the shoulders. Normally the bristles are straight and lie flat. Occasionally, I observed animals with rough, curly pelage, a trait which may have been a result of poor nutrition (National Research Council, 1968:23). The coat is sparse on the belly but relatively dense over the rest of the body. The winter coat is slightly longer and more dense than the summer coat.

The pelage of the European wild boar is longer and more dense than that of the feral hog, and the mane of the male may reach a length of 10 to 13 $\mathrm{cm}$. The wild boar also has a dense coat of fine, woolly underfur (Hofliger, 1931) which I observed on some wild pigs of Santa Catalina Island and Monterey County, California, but which was not present on the wild boar used for breeding at Dye Creek.

The Dye Creek feral hogs displayed 11 basic coat color patterns. I tabulated these patterns for 768 hogs tagged or individually identified in 1969. Solid black animals made up 46 percent of the sample. Other pure colors ranged from white to dark brown, but were arbitrarily classed as either buff or red. Spotted individuals included approximately 28 percent of the sample. Spotting ranged from black and white to black and dark brown, but usually a distinction could be made between buff and black versus red- and black-spotted hogs. The extent of the black spots varied from nearly complete coverage to only a few small spots.

Belting was another prominent color pattern in which the "belt" or "saddle" was always white, normally with a pattern of white skin underlying the pattern of white hair. Black-belted, redbelted, and buff-belted categories were recognized and together made up about 10 percent of the sample. Belts were rarely superimposed on spotted patterns and were placed in a belted category corresponding to their dominant background color. Belts varied in width from less than $2 \mathrm{~cm}$ to the whole length of the torso. Some belts had parellel margins and some were triangular, widening on either the ventral or dorsal part of the body. Some individuals displayed an incomplete belting pattern, but made up only 2 to 3 percent of the sample.

I observed three individuals which appeared to have a "variegated" or random pattern of white, red, brown, and black hair. However, these hogs were never captured for a close examination.

There are at least seven different loci determining coat color in pigs, each locus having two or more alleles (Searle, 1968:196-200). The Dye Creek population included the "agouti," "dominant black," "belting," "normal black," "tigering," and "yellow recessive" alleles.

The wild-type color pattern, as displayed by the European wild boar, is a reddish-brown to grey-black pattern with increasing grey hairs on the belly and jowls. The lighter patterns are a result of light bands of varying width on the individual hairs. This agouti pattern is controlled by a dominant allele (Searle, 1968), and feral hogs presumably have the recessive, nonagouti allele. The dominant black allele can mask the agouti pattern, and young from a black feral male $\times$ European type sow cross were all black. 
The longitudinal red- and blackstriped pattern of young wild boar is gencrally dominant and is often regarded as evidence of wild boar influence in a population of feral hogs. Hybrids may have distinct stripes or only "ghost" stripes. In 1967, before any known introductions of wild boar stock, two young feral piglets from the study area were observed with faint ghost stripes. A number of striped young appeared in the area after European-type boars were bred to feral sows. Stripes can occur over any color pattern except the belted pattern and black which is a result of the dominant black allele. The fact that some black young had faint stripes indicates the presence of the normal black allele.

\section{Number of teats}

The mean teat number of Dye Creek hogs is lower than in modern domestic breeds (Plum, 1938: Smith et al., 1938: 51), but higher than in wild boar (Nachtsheim, 1924). The number of teats on 197 feral sows from 5 subunits (Fig. 2) of the study area ranged from 10 to 16 . The mode was 12 teats in three of the subunits, 11 in one, and 10 in the last. Using the Chi-square test of homogeneity, I found no significant differences between the frequencies of teats for the five subunits. However, when the data for the two back-country subunits were compared with the data for the three pasture area subunits the difference was significant $(\mathrm{P}<0.02)$. The back country sows averaged 11.9 teats per animal and the pasture sows averaged 12.6. This difference could be due to natural selection or to differences in the original domestic stock.

\section{Behavior}

Pigs learn quickly (Hafez and Signoret, 1969:355), and are more adaptable than many ungulates to changing conditions. They will move if environmental conditions become unfavorable, and will change their food habits drastically and rapidly to make use of the best foods available. They will also modify their response to humans fairly rapidly if it benefits their survival.

The behavior of both wild boar and domestic swine has been investigated extensively (Fradrich, 1967; Fraser, 1968; Gundlach, 1968; Hafez and Signoret, 1969; Beuerle, 1975). The Dye Creek feral hogs displayed behavior patterns similar to or intermediate between the patterns of wild boar and domestic swine. Feral hogs depend on olfaction and audition more than vision (Wesley and Klopfer, 1962), and can be approached closely from downwind even in open country. Scent posts are commonly used, often in conjunction with body scratching behavior, and travel is normally along well defined trails which are located primarily by olfaction. Although sign-posting occurred, I saw no evidence of defended territories. Most of the vocal sounds described for domestic swine (Grauvogl, 1958) were emitted by the feral hogs.

Feral hogs have a matriarchal society, with males leaving their dam at age 9 to 12 months. Boars live singly except when joining groups for breeding or for feeding on localized food supplies. Of 1,384 observations, 18.5 percent were of single individuals, and all but a few of these were adult boars. Barrows generally traveled in pairs or small groups. The average size of 1,128 groups was 8.4 hogs, with monthly averages ranging from 6.0 to 10.5 . Groups or "sounders" included a sow and one to three generations of offspring. Although groups over 25 were rare, large herds up to 97 animals were seen when several family groups congregated in irrigated pastures. Members of a typical family group followed the oldest sow, and remained within about $30 \mathrm{~m}$ of each other while maintaining an "individual feeding distance" of $0.6-1 \mathrm{~m}$. 


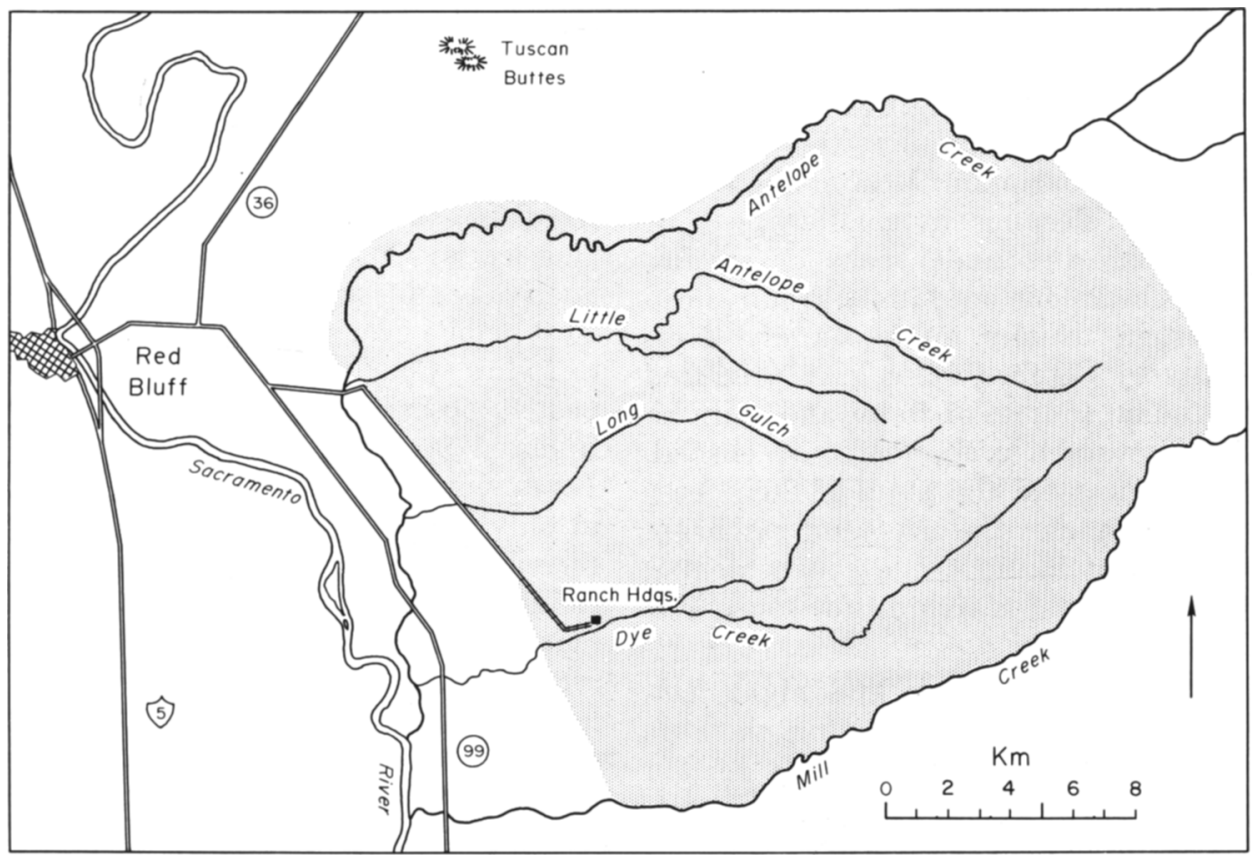

Fig. 9. Present range of the feral hog in eastern Tehama County, California.

Boars were dominant over sows and sows over young. Barrows were some- times subordinate to sows and always subordinate to boars (Barrett, 1971).

\section{MOVEMENTS}

\section{Range and distribution}

The range of the feral hog population in eastern Tehama County covers approximately $310 \mathrm{~km}^{2}$ of foothill country (Fig. 9). The largest concentration of animals occurs in the larger creek canyons, which have permanent water. The hogs prefer the lower north slopes supporting heavy thickets of live oaks and are found less frequently on ridges or plains. Their preference for the eight vegetational types described is in direct proportion to the density of cover, except for the irrigated pastures and boulder wash types which are heavily used for nocturnal feeding during the dry season (Barrett, 1971).

Hunting pressure is heavy on all accessible public lands to the north and east of the Dye Creek Ranch, and this appears to be a major factor limiting expansion of the feral hog's range.

A small feral hog population re- portedly exists northeast of the town of Paynes Creek, over $24 \mathrm{~km}$ north of the study area. Also, scattered pockets of feral hogs are found to the south between Mill Creek and Deer Creek. Interchange of hogs between the study population and the one north of Paynes Creek is doubtful, and there is probably little interchange across Mill Creek. Most of Mill Creek flows in a steep-walled channel which the hogs cannot cross, and I never saw any sign of hogs on the south bank.

\section{Activity patterns}

In general, seasonal temperatures affect the time at which activity occurs, and the availability of food influences the duration of activity and the distance traveled during feeding.

In autumn, the hogs assume their preferred pattern of crepuscular activity (Hafez and Signoret, 1969:352), and 
daily movements are minimal, often only a few hundred meters. Adult swine prefer temperatures of about $20^{\circ}$ C (Mount, 1968), and at this time the weather is optimum. Most of their time is spent sleeping in shallow beds or "moulds" dug under oaks or shrubs. Boars bed alone but family groups sleep together, usually quite soundly. Normally by October, rains have produced abundant sources of water and, with an average acorn crop, food is plentiful. The hogs spend almost all of their feeding time under the oaks, and gathering a meal entails little more than picking up acorns and searching for sources of protein.

As winter advances and night temperatures drop below freezing, the hogs become diurnal. They normally remain bedded all night in small caves scattered throughout the foothills, and may not arise until midmorning if the weather is cold and windy. As the acorns are consumed, the hogs shift to grazing and tend to travel farther while feeding. The animals are most easily observed during the winter and spring because they move during the day and spend more time in open country.

As summer approaches, with rising temperatures and drying vegetation, the hogs resume a crepuscular activity pattern, then shift to a nocturnal one, resting through the hot days and emerging only at dusk. Summer beds are located in dense oak thickets or grape tangles, often on lower, north slopes near water. Food resources are relatively scarce in the summer, and the hogs are forced to travel up to $10 \mathrm{~km}$ daily and feed throughout the night with only occasional short rest periods. By daybreak, or soon after, they return to their beds. I never observed a hog traveling at midday during the summer unless it was disturbed. Hogs normally traveled at a rate of $5 \mathrm{~km}$ per hour, although when alarmed they could cover up to $5 \mathrm{~km}$ at $16 \mathrm{~km}$ per hour.

\section{Home range}

There was a noticeable difference in the degree and frequency of movements between hogs of diffrent sex and reproductive condition. Adult boars were the most mobile group and the most difficult to follow. Conclusions are based on repeated observations of marked boars followed for periods of up to 2 years. Boars moved up to 11 airline kilometers in only a day or two. They had a preferred area but from there they often ranged in one direction or another in search of breeding opportunities. They sometimes spent a week or more in one location and then appeared with another family group up to $11 \mathrm{~km}$ away in a different canyon. The home range of Dye Creek males is at least $50 \mathrm{~km}^{2}$.

Adult sows traveled much less than boars, especially when they had litters. I followed the movements of 16 sows for 1 year, and several sows were followed for up to 2 years. The typical home range of Dye Creek sows is 10 and rarely $25 \mathrm{~km}^{2}$. Home ranges normally included two or three adjacent canyons. Seasonal shifts were common within this range, and during any given month sows used only a part of their annual home range. Sows with young less than 3 weeks old rarely moved more than $0.5 \mathrm{~km}$ from their nest. There was no evidence of major home range shifts by Dye Creek sows, and the small seasonal shifts could be explained by seasonal variations in temperature and availability of food and water.

Adult barrows do not expend energy on reproduction, and thus need to spend less time gathering food. Moreover, they usually are quite fat and move with greater difficulty. They remained close to their food source throughout the year, and tended to travel even shorter distances than sows. Barrows were seen less often than other hogs because of their relatively re- 
stricted activity pattern. Typical home ranges and movements observed for Dye Creek hogs are shown in Figs. 10 and 11.

These findings are similar to those of other studies which have suggested that wild pigs normally have home ranges

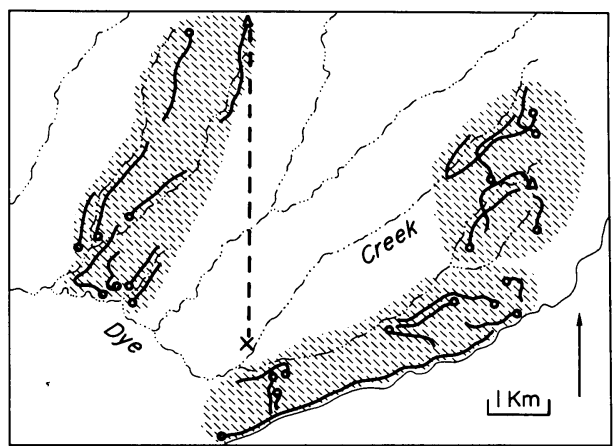

Fig. 10. Movements and home ranges of three individual adult feral sows of different family groups, and the trap site (triangle) and kill location (X) of an adult boar. Dots and heavy lines indicate observations and observed movements.

of 5 to $30 \mathrm{~km}^{2}$ (Lewis, 1966; Vereschagin, 1967; Kurz and Marchinton, 1972; Pine and Gerdes, 1973). Wild pigs have been known to travel longer distances, up to $210 \mathrm{~km}$ (Sludskii, 1956), and they may exhibit distinct seasonal migrations (Rakov, 1956; Vereschagin, 1967). Most authors have concluded that wild pigs are irregularly sedentary animals. They remain in an area with suitable cover only so long as sufficient

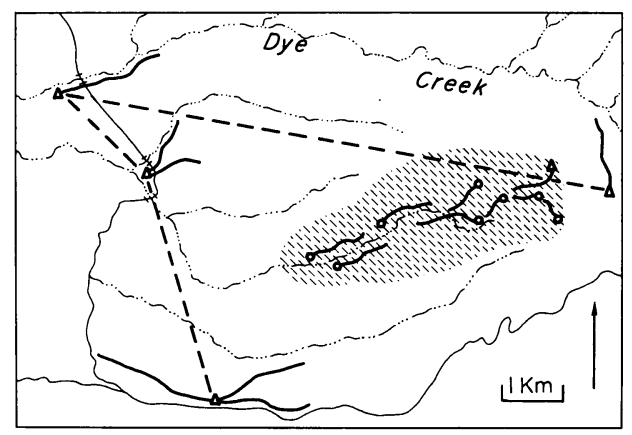

Fig. 11. Movements and home range of a barrow and trap sites (triangles) for an adult boar joined by dashed lines. Dots and heavy lines indicate observations and observed movements. food and water are available, but will shift their home range as a result of drought, flooding, or severe disturbance (Wodzicki, 1950; Oloff, 1951; Sludskii, 1956).

\section{Dispersal}

Most young established home ranges within or adjoining that of their dam. The farthest known shift was by a young sow which established its home range approximately $3 \mathrm{~km}$ from that of its mother. The sow was less than a year old when it left its mother and had its first litter in its new home range. Several yearling boars were seen most often at distances up to $1.5 \mathrm{~km}$ from areas where they had been commonly seen with their dams when young. However, their home ranges included most of their dam's range.

Blocker (1937) and Ling (1955) reported a dispersal rate of $4-5 \mathrm{~km}$ per year for wild boar. Ling also pointed out that range extension begins with "accidental" boars invading an area, and "improving" it by making beds and trails. Next, sows, particularly young animals, immigrate and colonize the area. Accidental boars have been seen in the Sacramento Valley west of Dye Creek, and on the Tuscan Ranch to the north. If these individuals were not regularly eliminated, feral hogs would undoubtedly colonize the riparian woodlands and oak thickets in these areas.

\section{Homing ability}

Fifteen groups of feral hogs were transplanted during the study to determine: (1) the distance necessary to move animals to stop pasture damage, and (2) the best class of hogs to establish new populations. Three groups were never seen again after their release. One or more individuals of seven groups returned 4 to 11 airline kilometers to their original capture site. Adults led younger hogs in most of these cases, and the return was appar- 
cntly deliberate and immediate (Barrett, 1971).

Transplant experiments by Lewis (1966), Matschke and Hardister (1967) and Pine and Gerdes (1973) indicated wild boar will not return if moved at least $20-22 \mathrm{~km}$ to suitable habitat. The Dye Cresk data (Barrett, 1971) neither confirm nor contradict this conclusion. However, they do suggest that if sows with litters, late pregnant sows, or young hogs are transplanted after being held in captivity for a period, these groups may be successfully transplanted less than $20 \mathrm{~km}$ if the release site includes cover, water, and readily available food.

TABLE 4

A. NUMBER OF FERAL-HOG STOMACH SAMPLES ACCORDING TO AGE AND SEX
B. NUMBER OF FERAL HOGS COLLECTED ACCORDING TO AREA AND SEASON

\begin{tabular}{|c|c|c|c|c|c|c|}
\hline Age and sex & Number of samples & \multirow{2}{*}{ Month } & \multirow{2}{*}{$\begin{array}{c}\text { Pasture } \\
(1968-70)\end{array}$} & \multicolumn{2}{|c|}{ Foothill } & \multirow{2}{*}{ Total } \\
\hline \multirow{8}{*}{$\begin{array}{l}\text { Adult }(12+\text { mo. }): \\
\text { Female } \\
\text { Male } \\
\text { Sub-total } \\
\text { Young }(-12 \text { mo. }): \\
\text { Female } \\
\text { Male } \\
\text { Sub-total }\end{array}$} & & & & '67-'68 & $' 68-' 70$ & \\
\hline & 53 & Jan. & 6 & 0 & 4 & 10 \\
\hline & 63 & Feb. & 9 & 3 & 6 & 18 \\
\hline & 121 & Mar. & 18 & 2 & 23 & 43 \\
\hline & 10 & Apr. & 8 & 0 & 8 & 16 \\
\hline & $\begin{array}{r}10 \\
3\end{array}$ & May & 1 & 0 & 1 & 2 \\
\hline & $\begin{array}{r}3 \\
13\end{array}$ & June & 2 & 0 & 1 & 3 \\
\hline & & July & 6 & 0 & 0 & 6 \\
\hline \multirow[t]{6}{*}{ Total } & 135 & Aug. & 4 & 1 & 0 & 5 \\
\hline & & Sept. & 3 & 1 & 1 & 5 \\
\hline & & Oct. & 3 & 0 & 0 & 3 \\
\hline & & Nov. & 2 & 1 & 4 & 7 \\
\hline & & Dec. & 4 & 3 & 9 & 16 \\
\hline & & Total & 66 & 11 & 57 & 134 \\
\hline
\end{tabular}

\section{FOOD HABITS}

Two questions raised at the outset of the study were: (1) To what extent do the irrigated pastures provide food for the feral hogs and (2) What effect does this food have on their growth and reproduction? Consequently, the study area was divided into two areas on the basis of whether or not hogs had access to summer irrigated pastures. Food habits were compared between the "control" area in the foothills and the pasture area along the edge of the valley. In addition, data for 2 successive years are given for the foothill area to illustrate annual variation in food habits. Thus, results are presented under three categories: (1) pasture area, 1968 to 1970; (2) foothill area, 1968 to 1970; and (3) foothill area, 1967 to 1968. Information on food habits was obtained by analysis of stomach contents, analysis of scats, and field observations of hogs feeding. The latter two supplemented the findings from the stomach samples.

A total of 134, one-liter-sized samples were collected from thoroughly mixed hog stomach contents and preserved in 10 percent formalin. Most animals were killed by hunters; the collection data are given in Table 4. All samples were analyzed at the end of the collection period. They were washed in a series of two sieves (mesh no. 16 and 27), and spread thinly while still wet in shallow dissecting pans. The volume percent of each food item was visually estimated under a low-power dissecting scope (Korschgen, 1969:242). If estimates of composition varied greatly between sieve 
subsamples, which only occurred with fine food items like acorn meal, adjustments were made for the recorded composition. Samples were analyzed at random, and to avoid bias the collection data were not referred to until the analysis was complete.

A total of 4,932 scats was analyzed in the field as they were found and recorded in one of four classes of food items: (1) grass, forbs, and browse; (2) bulbs; (3) berries; and (4) acorns (Barrett, 1971).

\section{Pasture area 1968 to 1970}

Sixty-six stomach samples were collected in the pasture area from July, 1968 to January, 1970. There were good acorn crops in the fall of 1968 and 1969, and the pattern of food available during each season was similar for both years. The monthly changes in volume percent of each of the major food items (Fig. 12) are based entirely on stomach samples. Data from scats and field observations substantiate the results from stomach samples.

In the early spring, feral hogs spent most of their feeding time grazing green grasses and forbs. They preferred filaree and clovers which made up most of the forb category. During May, as the range dried up, the animals concentrated on wild oats and bulbs. Bulbs continued to be an important food item through the summer, but by July, hogs spent much of their feeding time in irrigated pastures. Although they ate a greater quantity of perennial pasture grasses (mainly Dallas grass and Bermuda grass) than pasture forbs, the hogs seemed to prefer white clover which was less abundant than grass.

Beginning in September, the hogs fed more and more heavily on acorns, and from October to December acorns comprised most of the diet. In a good acorn year this item may remain in the diet until February. By mid-November the fall rains had stimulated the growth of green range forage, and the hogs began to graze as the acorns were depleted.

Other food items included roots of herbs (particularly filaree), manzanita berries, and animal matter. Animal matter comprised only 1.6 percent of the total annual volume; however, this small amount probably was vital to the hogs' well-being. Carrion was the major animal matter eaten, but earthworms and various insects and their larvae were also consumed.

\section{Foothill area 1968 to 1970}

The results for the foothill area (Fig. 13) are based on 57 stomach samples taken from July 1968 to January 1970, and on scat analyses and field observations for the summer months. Except for the summer diet, the seasonal pattern was similar to that described for the pasture area.

The summer foods in the foothills included green grass, dry grass, and browse. The only green grass available through the summer grew around springs, and these areas were heavily utilized by the hogs. Because green grass was in short supply, the hogs resorted to stripping poison oak leaves from the numerous shoots in the live oak thickets, and finally to stripping the seed heads from the dry soft chess and fescues. As summer progressed, the hogs ate manzanita berries as these became available. Manzanitas were relatively scarce, and nearly every plant was rooted under during that time of year. The berries were consumed almost as soon as they fell, but due to their scarcity they made up a small part of the diet.

\section{Foothill area 1967 to 1968}

Although based on only 11 stomach samples and 1,131 scats, plus general observations, Fig. 14 indicates the great annual variation in food habits. In the fall of 1967 the acorn crop failed, but 


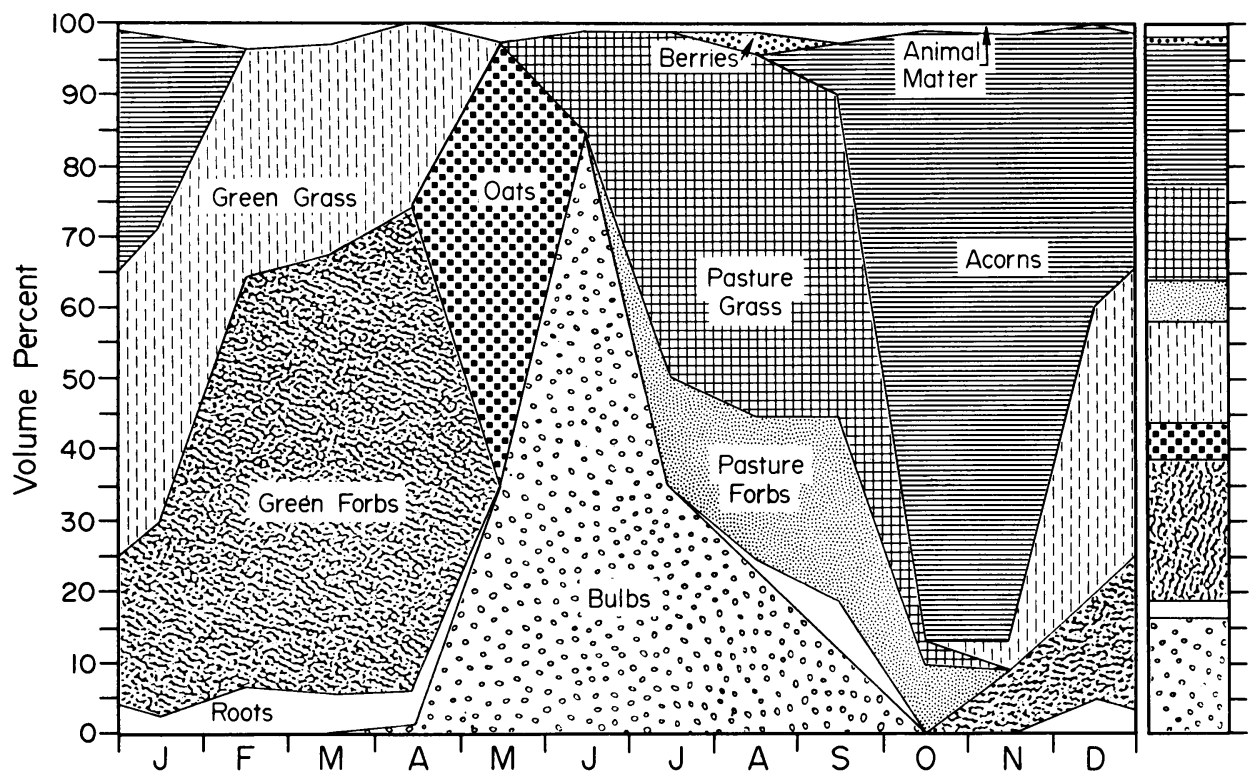

Fig. 12. Monthly variation in the feral hogs' diet and an annual composite for the pasture area, 1968-1970. The diagram is based on the volume percent of major food items found in 66 stomach samples.

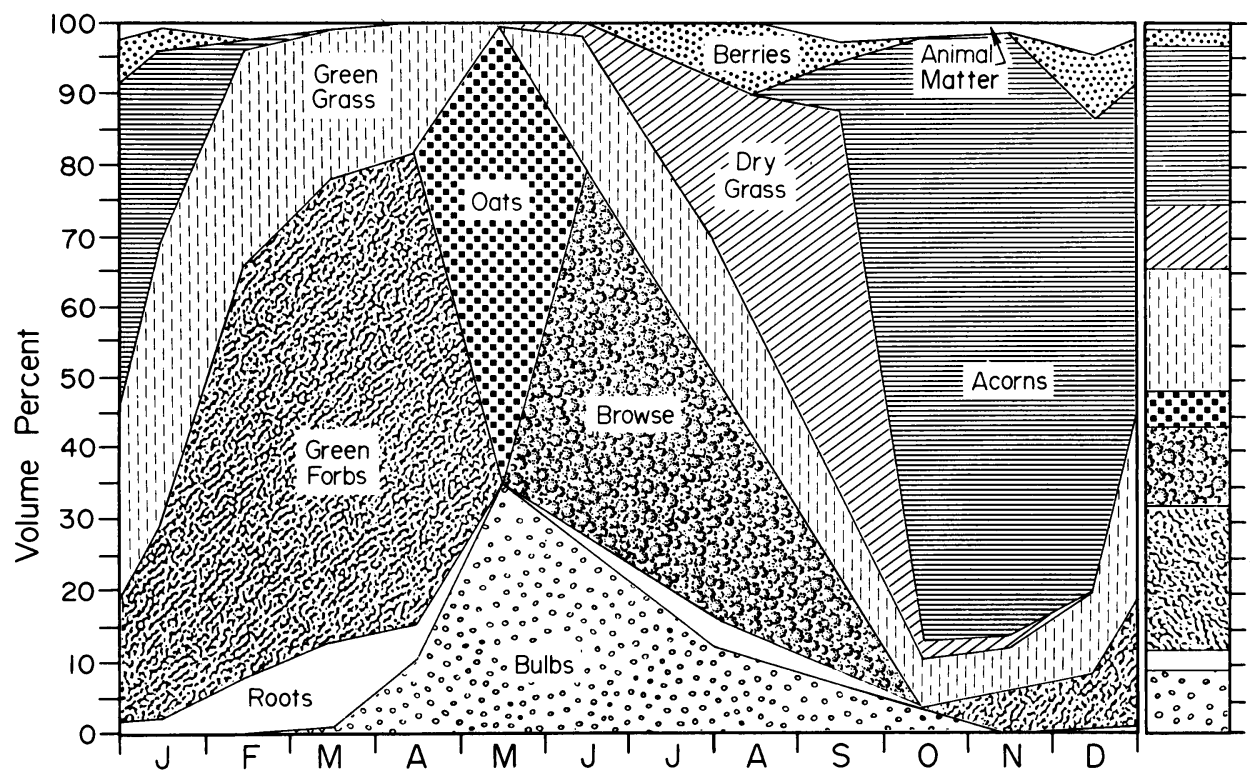

Fig. 13. Monthly variation in the feral hogs' diet and an annual composite for the foothill area, 1968-1970. The diagram is based on the volume percent of major food items found in 57 stomach samples and on scat analyses and field observations for the summer months. 


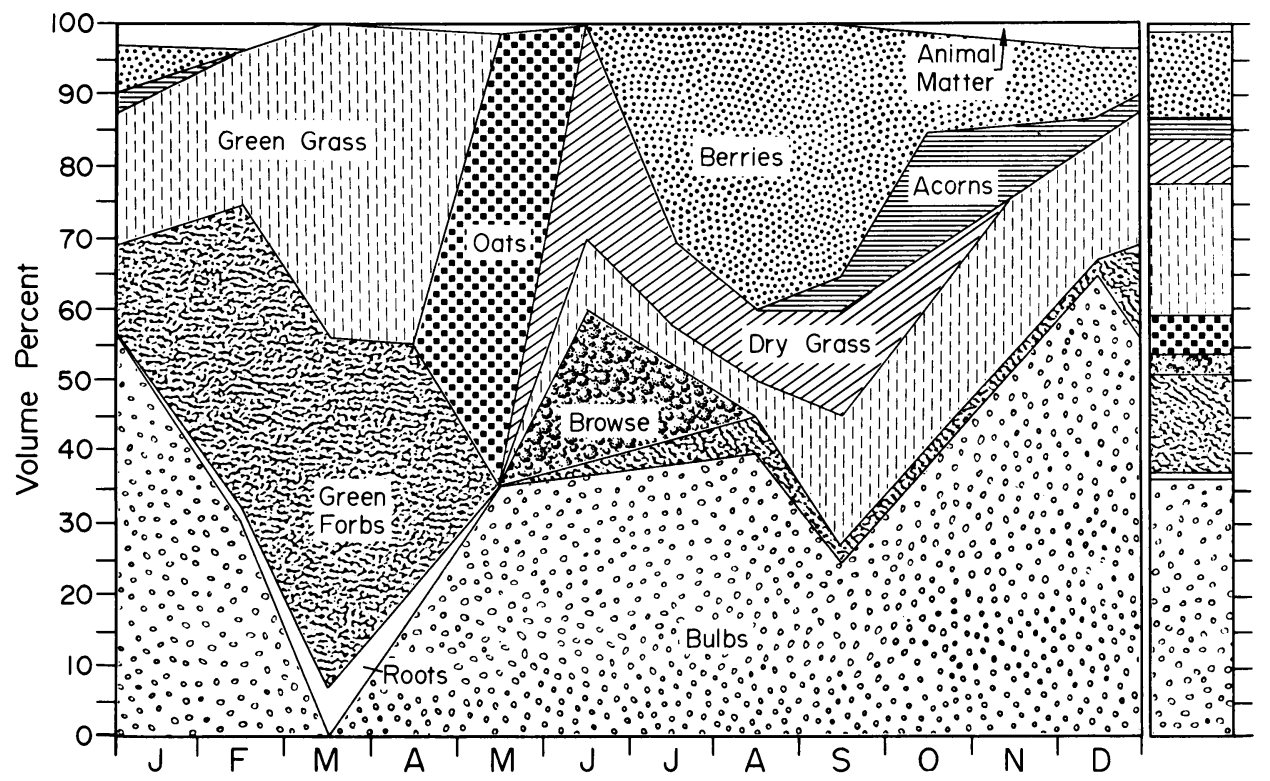

Fig. 14. Monthly variation in the feral hogs' diet and an annual composite for the foothill area, 1967-1968. The diagram is based on the volume percent of major food items in 11 stomach samples, and on scat analyses and field observations.

the manzanita berry crop was good. As a result, the hogs relied on bulbs as a major source of energy and ate a greater percentage of manzanita berries than in the following years. A greater than normal amount of rooting occurred in the foothills during that winter, which suggests that the hogs were seeking bulbs.

\section{Discussion}

There was no apparent variation in food habits between sexes or ages, with one exception. Adult boars tended to eat more carrion than other hogs due to their ability to dominate a carcass. They also moved farther and more often than sows or barrows which probably increased their chances of encountering carcasses. The major variation between the stomach samples was a result of seasonal availability of preferred food items which is related to four factors: (1) presence or absence of a vegetational type within a hog's home range, (2) phenology of the vegetation, (3) annual fluctuation in vege- tational production, and (4) inter- and intraspecific competition for food items.

The adaptability of the omnivorous hog is evidenced by the abrupt and radical, seasonal changes in its food habits. For example, in May the animals concentrated on wild oats which flowered and set seed within about 3 weeks. In the autumn when acorns began to drop, the hogs shifted to an acorn diet within 2 weeks. Manzanita berries were eaten in the late summer, but they were left in deference to acorns in the autumn. After the acorns were consumed the hogs returned to finish the manzanita berries.

The above results agree with most previous studies, which have generally noted a predominance of vegetable matter in wild pig diets, particularly mast or energy-rich root crops (Rakov, 1956; Janda, 1958; Briedermann, 1967; Kornyeyev and Krychevs'ka, 1967; Henry and Conley, 1972; Pine and Gerdes, 1973). However, wild boar may eat a majority of animal matter (Haber, 1966), and all of the above studies in- 
dicate that the wild boar consumes more animal matter than did the Dye Creek hogs.

The diets of the foothill hogs and the pasture hogs were similar, with the important exception that during the sum- mer the latter consumed a much greater proportion of green herbage including much white clover. It will be shown that this resulted in a significant difference in growth and reproduction between the two populations.

TABLE 5

DAILY NUTRIENT REQUIREMENTS OF DOMESTIC SWINE

\begin{tabular}{|c|c|c|c|c|c|c|}
\hline \multirow{3}{*}{ Item } & \multicolumn{6}{|c|}{ Class of swine (live weight, $\mathrm{kg}$ ) } \\
\hline & \multicolumn{3}{|c|}{ Growing pigs } & \multirow{2}{*}{$\frac{\text { Bred sows }}{110-160}$} & \multirow{2}{*}{$\begin{array}{c}\begin{array}{c}\text { Lactating } \\
\text { sows }\end{array} \\
136-200\end{array}$} & \multirow{2}{*}{$\frac{\text { Boars }}{110-180}$} \\
\hline & $5-10$ & $10-20$ & $20-35$ & & & \\
\hline \multicolumn{7}{|l|}{ Digestible energy: } \\
\hline $\mathrm{Kcal} / \mathrm{kg}$ of forage & 3,500 & 3,500 & 3,300 & 3,300 & 3,300 & 3,300 \\
\hline Kcal/day & 2,100 & 4,370 & 5,610 & 6,600 & 16,500 & 8,250 \\
\hline \multicolumn{7}{|l|}{ Total feed: } \\
\hline (air dry wt., kg) & 0.6 & 1.3 & 1.7 & 2.0 & 5.0 & 2.5 \\
\hline \multicolumn{7}{|l|}{ Crude protein: } \\
\hline Percent of diet & 22 & 18 & 16 & 14 & 15 & 14 \\
\hline Grams/day & 132 & 225 & 272 & 280 & 750 & 350 \\
\hline
\end{tabular}

SOURCE : National Research Council (1968).

\section{NUTRITION}

The detailed data now available on the nutritional needs of the pig are responsible for much of the improvement in domestic swine production since 1900 (Ensminger, 1961:163). The pig is a monogastric animal; thus, it is not well adapted to feeding solely on roughage and must obtain certain essential amino acids and vitamins from its diet (Cunha, 1957; Hafez and Dyer, 1969). Protein needs are particularly great for young pigs and lactating sows (Table 5). Animal matter is the best source of essential amino acids, but young, fresh forbs, particularly legumes, provide reasonably high-quality protein (Rérat, 1972).

The energy and protein content of the major food items described above were analyzed to further clarify: (1) their relative nutritional importance, (2) their nutritional value in comparison with common domestic swine feeds, and (3) the nutritional significance of the difference in summer food habits between the pasture and foothill hogs.
Few data are available from digestive trials using the foods eaten by wild pigs. Because digestive trials are relatively difficult, only simple proximate analyses were conducted. Some idea of digestible energy can be gained by comparing the results of proximate analyses of feral hog food items with similar data for more common swine feeds, for which the digestible energy is known (Table 6). Caution should be used in interpreting the data, since moisture values are not available.

\section{Acorns}

The acorn is the most important food item in the Dye Creek area. Without this, the area could not support the present density of wild pigs. Production and digestibility data for the local acorns are not available, but information is available from studies made in Spain where oak woodlands support a major swine industry (Parsons, 1962). Torrent et al. (1962) gave a digestibility of 74 percent for dry acorn Quercus 
ilex flour which approaches the digestibility of corn, 92 percent (Table 6 ).

Hogs effectively removed the hull from most of the acorns they ate. I estimated that hull made up less than 13 percent of the total volume of acorn matter in 15 stomach samples. This practice improves the digestibility of the acorns by reducing the intake of crude fiber and tannins which inhibit protein digestion (Morrison, 1956:498). In Spain, 15- to 21-month-old swine, weighing 50 to $70 \mathrm{~kg}$, were allowed to forage for acorns in the autumn. These swine ate 5.9 to $7.2 \mathrm{~kg}$, wet weight (2.7 to $4.1 \mathrm{~kg}$, dry weight), of acorns per day and gained 0.7 to $0.8 \mathrm{~kg}$ per day, or a total of about $68 \mathrm{~kg}$ in 3 months (Torrent et al., 1962). Candau (1959) found that it took 6.4 and $11.9 \mathrm{~kg}$ of acorns to produce a gain of $1 \mathrm{~kg}$ in swine weighing 8 and $66 \mathrm{~kg}$, respectively. Similar weight gains were made by the Dye Creek feral hogs during a good acorn season. Gains of $0.5 \mathrm{~kg}$ per day were common for yearling pigs, and sows which were in poor condition after lactating gained up to $1.0 \mathrm{~kg}$ per day on an acorn diet.

Acorns contain relatively little crude protein in relation to total energy (Lund and Sandstrom, 1943). Therefore, when the hogs were feeding heavily on acorns, protein probably was a major factor limiting efficient gains. In the autumn, hogs actively sought sources of animal matter and green forage, and the period of most severe rooting in the irrigated pastures occurred during October and November before the foothills had turned green. At that time the pasture hogs fed on acorns in the hills but rooted for earthworms and insect larvae in the pastures. Torrent et al. (1962) noted that pigs gain faster when green forage is available along with acorns. They also suggested that to make the most efficient use of the acorn crop, a yearling pig should be given a supplement of $140 \mathrm{~g}$ of digestible pro- tein per day. It is very unlikely that Dye Creek hogs were consuming this much protein.

These authors also gave some figures for the carrying capacity of the Spanish oak woodland. This woodland or "encina" is managed specifically for acorn production, mainly by pruning the oaks (Ruperez-Cuellar, 1957). A woodland with six trees per hectare produced a perennial average of $645 \mathrm{~kg}$ of acorns per ha. This crop can support approximately 0.3 yearling pigs per hectare, or $180 \mathrm{pigs} / \mathrm{km}^{2}$, for 3 months. The Dye Creek oak woodland appeared to be much less productive than the Spanish cncina, but this information gives some idea of what the carrying capacity could be during the acorn season.

\section{Berries}

Manzanita berries were the only other type of mast commonly eaten by Dye Creek hogs. Approximate analysis showed that the berries are very high in crude fiber, and thus are a relatively poor energy food (Table 6). The hogs stopped feeding on berries entirely if sufficient acorns were available. The fact that the foothill hogs sought the berries during the summer indicates that their level of nutrition was quite low at that time of year.

\section{Wild oats}

Wild oats were utilized for only a short period of the year, but were an important and readily obtainable energy source during May. The data in Table 6 are for Avena fatua which has a slightly larger grain than Avena barbata, the oat found in the study area. The crude fiber would be higher, and the carbohydrate content slightly lower, for A. barbata. Even so, it is apparent that with a digestible energy of approximately $2,822 \mathrm{Kcal} / \mathrm{kg}$ of dry matter, this food item is a better source of energy than all the other food items except acorns. 


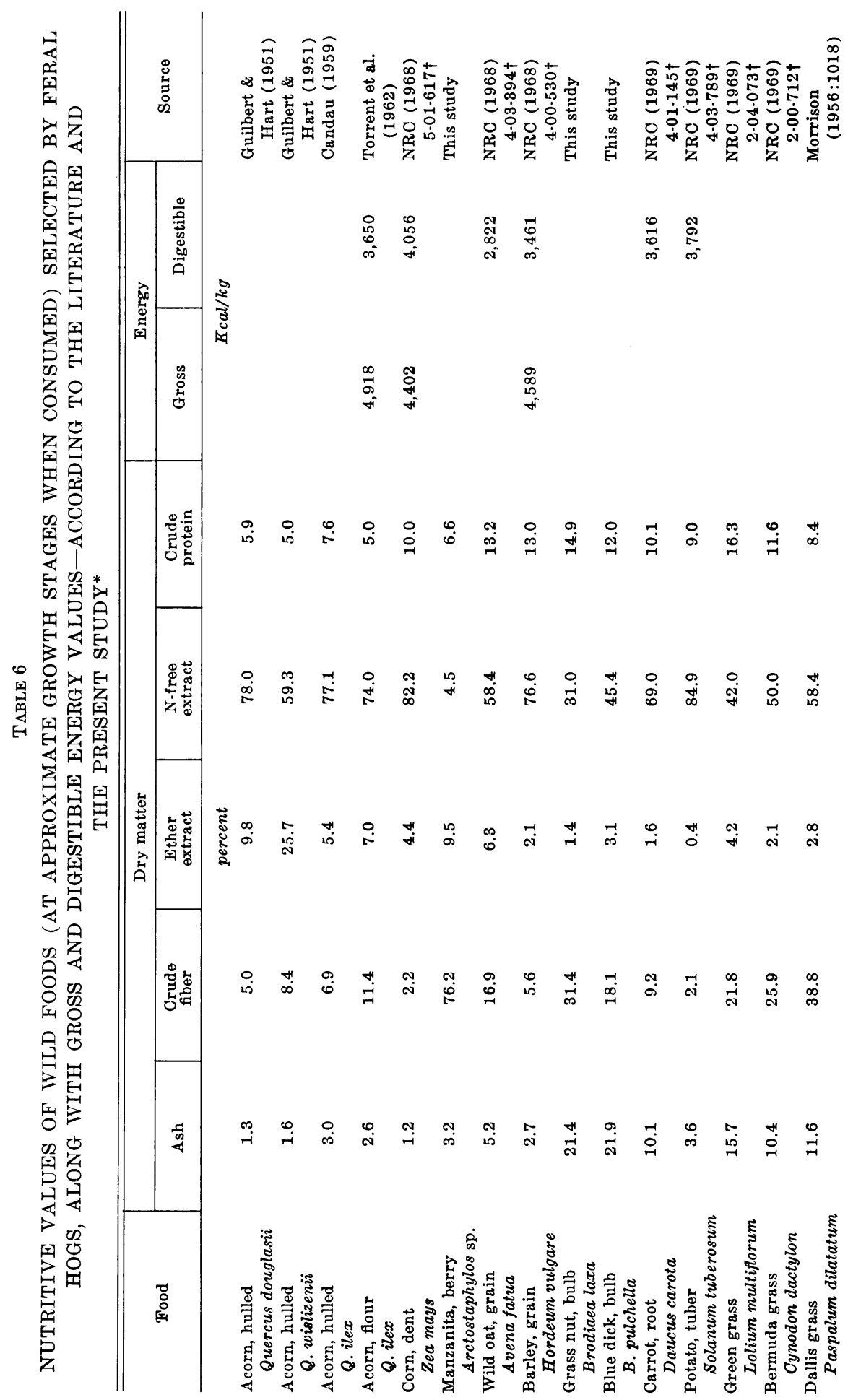



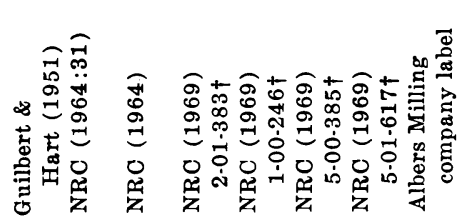

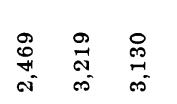

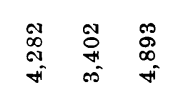

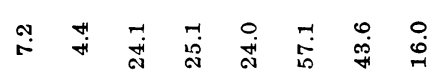

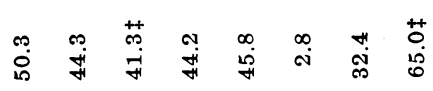

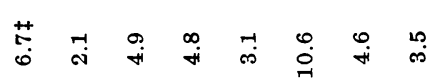

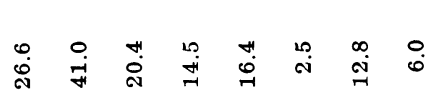

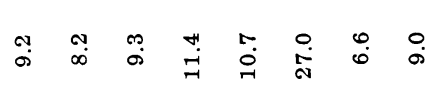

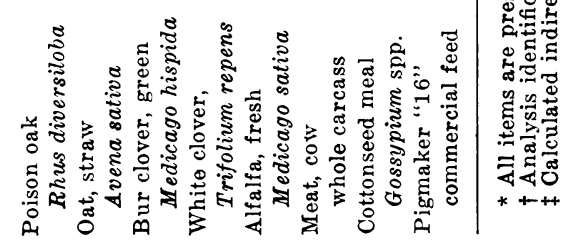

\section{Bulbs}

Proximate analyses of two species of Brodiaea bulbs showed a very high ash content (Table 6), probably due to incomplete washing of soil from the outer coat of the bulbs. Bulbs were thought to be similar to other root crops like carrots or potatỏes in having a high carbohydrate content. Due to the method of calculating the results from a proximate analysis, a higher nitrogenfree extract value would have been obtained if the ash content had been lower. The value of Brodiaea bulbs is diminished because they have a high moisture and fiber content and require more energy to gather than acorns or berries. However, during the summer and during poor acorn years, bulbs are the major source of energy.

\section{Grass}

Grass made up a large part of the feral hogs' diet, but it is a relatively poor source of energy because most of its carbohydrate content is in the form of cellulose. The digestible energy value for green grass is lower than for energy foods such as acorns (Forbes and Hamilton, 1952; Krider and Carroll, 1971:395), and is probably lower than that for alfalfa (58 percent digestibility).

Although the pig has no rumen, its alimentary tract does contain microorganisms capable of fermenting cellulose into volatile fatty acids (VFA) which are metabolized (Cranwell, 1968; Horszczaruk, 1971). VFA concentration in the stomach, duodenum, and caecum of 31 feral hogs was determined by gas chromatography (Barrett, 1971). The results (Table 7) confirm that microbial fermentation is an important process in feral hog digestion. There was no significant correlation of total VFA content with food items in the stomach or with estimated time since feeding. 
TABLE 7

AVERAGE VOLATILE FATTY ACID CONCENTRATIONS IN 30-STOMACH, 29-DUODENUM, AND 31-CAECUM SAMPLES FROM FERAL HOGS COLLECTED OVER ALL SEASONS

\begin{tabular}{|c|c|c|c|c|c|c|}
\hline Organ & $\begin{array}{l}\text { Acetic } \\
\text { acid }\end{array}$ & $\mathrm{SE}^{*}$ & $\begin{array}{l}\text { Propionic } \\
\text { acid }\end{array}$ & $\mathrm{SE}^{\star}$ & $\begin{array}{l}\text { Total } \\
\text { VFA }\end{array}$ & SE \\
\hline & \multicolumn{6}{|c|}{$\mathrm{mg} / 100 \mathrm{ml}$} \\
\hline Stomach & 202.9 & 28.7 & 113.2 & 16.7 & 390.9 & 51.2 \\
\hline Duodenum & 62.0 & 12.7 & 6.7 & 0.8 & 74.6 & 13.9 \\
\hline Caecum & 646.3 & 30.2 & 123.0 & 12.4 & 905.4 & 49.4 \\
\hline
\end{tabular}

* SE $=$ Standard Error.

\section{Forbs}

Green forbs are similar to grass in having an energy content mainly in the form of cellulose. The digestible energy available per pound of forbs eaten varies inversely with the moisture content, but would be roughly comparable to $2,425 \mathrm{Kcal} / \mathrm{kg}$ of dry matter, the figure given for alfalfa (Table 6). Forbs, especially clovers and other legumes, contain nearly twice as much crude protein as grasses (Gordon and Sampson, 1939), and this is undoubtedly the reason why the hogs selected white clover in the pastures and bur clover and native clovers in the foothills.

\section{Crude protein consumption}

Animal matter averaged only 1.5 percent of the feral hog's diet; therefore, plant foods must provide a large portion of their protein intake. A cup-sized sample was collected from each of 68 thoroughly mixed stomach contents. These samples were frozen within 1 to 4 hours after the death of the hog and analyzed for crude protein by the Kjeldahl method. Although no control data are available, the results appear to be quite realistic when compared with the known crude protein values for some of the plant foods eaten.

Seasonal change in crude protein levels in the diets of the pasture and foothill hogs were not significantly different in the spring and autumn; therefore, the data for these seasons were combined (Fig. 15). The winter-spring crude protein level was significantly higher $(\mathrm{P}<0.01)$ than the autumn level. This difference can be attributed to the difference in crude protein values for grasses and forbs versus acorns which dominated the diets during the two respective seasons.

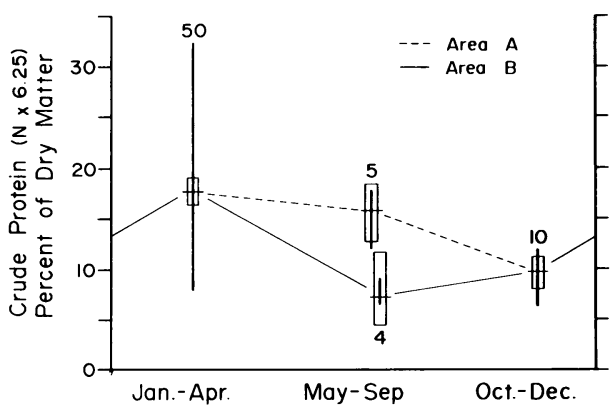

Fig. 15. Seasonal changes in crude protein content of feral hog stomach samples from the pasture area (A) and foothill area (B). Means are indicated by a horizontal bar, ranges by a vertical bar, and the enclosures indicate the 95 percent confidence interval. Sample size is given above or below the range bars.

During the summer, the crude protein level of the pasture hogs' diet was significantly $(P<0.01)$ higher than that of the foothill hogs' diet. This difference is due to the use of green grasses and forbs by the pasture hogs, and the use of dry grass, manzanita berries, and browse by the foothill hogs. The back country food items are all lower in protein content than green grasses and forbs. The foothill hogs' suboptimal protein intake only intensifies the adverse effects of their low energy diet. 
Much of the great variation in the crude protein values during winter and spring can be accounted for by variation in the percentage of forbs in the diet (Fig. 16) as indicated by a significant correlation of crude protein content with volume percent of forbs in 55 stomach samples collected during winter and spring, and during summer from pasture hogs only. The regression indicates that a nearly pure forb diet produces a crude protein level of over

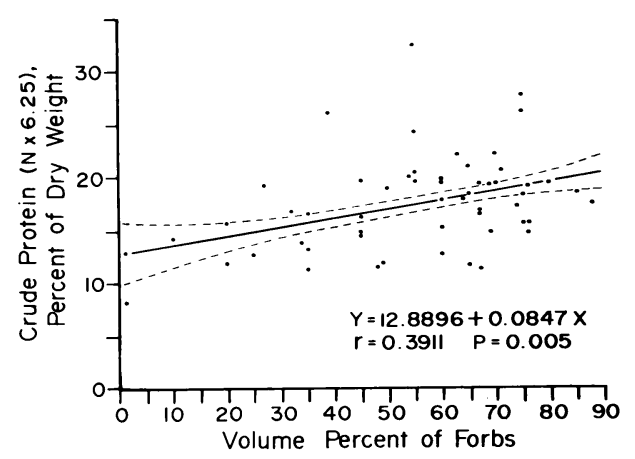

Fig. 16. Relationship of crude protein content to the volume of forbs in the winter, spring, and summer-pasture feral hog stomach samples. The dashed lines indicate the 95 percent confidence limits for the regression.
20 percent which is quite comparable to the crude protein values given in Table 6 for forbs. Furthermore, the crude protein level with no forbs in the diet is about 13 percent, and is comparable to the crude protein values given in Table 6 for green grass, which made up the remainder of the diet.

\section{Discussion}

The data presented here do not enable a precise analysis of nutrient intake rates, but they strongly suggest that the feral hog's diet is seasonally deficient in energy and protein. None of the food items provide the level of nutrition commonly given domestic swine. The summer deficiencies, especially of protein, are particularly marked for young and lactating hogs in the foothills. In autumn, even though the hogs may obtain sufficient energy from an acorn diet, protein deficiencies probably are reducing efficient use of this energy source. The grass-forb diet during the spring probably is well balanced, but because of its high and relatively undigestible cellulose content, the hogs cannot consume enough feed to provide optimum energy levels.

\section{GROWTH}

I attempted to (1) determine if the two nutritional regimens described above cause significant differences in growth pattern between the pasture and foothill hogs, and (2) compare these growth patterns with that of domestic swine. I expected significant differences in both cases since it has been shown that pig growth is very plastic in response to several environmental factors (McMeekan and Hammond, 1940; Weaver and Ingram, 1969).

An analysis of covariance was carried out on 1,001 multivariate observations (Table 8) using the DANIEL linear least-squares curve fitting program (Daniel and Wood, 1971) for the CDC 6400 computer. Most of the observa-

\section{TABLE 8}

DISTRIBUTION OF 1,001 FERAL HOG GROWTH OBSERVATIONS AMONG VARIOUS CATEGORIES

\begin{tabular}{l|c|c}
\hline \multicolumn{1}{c|}{ Category } & Number & Percent \\
\hline Sex & & \\
Male & 422 & 45.0 \\
Female & 515 & 55.0 \\
Barrow & $64^{*}$ & \\
Seasont & & \\
$\quad$ Summer & 748 & 79.8 \\
Winter & 189 & 20.2 \\
Location & & \\
$\quad$ Pasture area & 616 & 65.7 \\
Foothill area & 321 & 34.3 \\
Age group & & \\
Young (-30 mo.) & 805 & 85.9 \\
Adult (30+ mo.) & 132 & 14.1 \\
\hline
\end{tabular}

* Barrows not included in analysis of covariance. $\dagger$ Summer-May through September, Winter-October through April. 
tions were from different individuals. Those hogs measured more than once were aged according to their tooth pattern at the time of measurement regardless of any previous age estimates. Most samples were obtained in 1968 and 1969, and a few were obtained in 1967. For each observation the following data were included: sex, season, location, age group, live weight, total length, head length, tail length, shoulder height, ear length, hock length, and heart girth. Sex, season, location, and age group were considered as the independent variables.

For purposes of this discussion, age will be considered as an exact independent variable. It should be remembered, however, that these ages are really age groups, and the following analysis depicts the regression of growth parameters on tooth eruption and wear, not necessarily on true age. Although there is some individual variation in tooth eruption and wear, nutritional level affects tooth eruption less than it does weight or body size (McCance et al., 1961; Matschke, 1967; Sweeney et al., 1971). Differences in growth between two nutritional levels would likely be underestimated using tooth eruption age groups instead of true age; thus, statistically significant differences found in the following analyses are undoubtedly real.

The data were transformed with a curvilinear function to remove most of the variation due to age in the analysis of covariance. Many workers have wrestled with the problem of fitting curves to growth data, and no single function has been found to rationally describe the growth of an organism throughout its lifetime (Thompson, 1942; Brody, 1945; Simpson et al., 1960:373; Wood et al., 1962; Laird, 1966). In this case it was only possible to work with averages of many observations and a rational function was not necessary. Therefore, an empirically derived formula (Dudzinski and Myky- towycz, 1961; Myers and Gilbert, 1968) was used:

$$
\log _{10} Y=a+b\left(\frac{1}{X+K}\right)
$$

where $Y$ is live weight in kilograms or size in centimeters, $X$ is age in months, and $a$ and $b$ are growth constants. The constant $K$ was determined for each growth parameter by iterative means. The logarithm of the dependent variable was used to remove heterogeneity in the variance between age groups.

Initial analyses of covariance were made including all interactions between independent variables other than age. In most cases, interactions and main effects which were not statistically significant at the $P=0.05$ level were dropped from the model. Few interactions were significant. Finally, separate regression curves were fitted to the combined data for each sex, using the same $K$ value in the transformation formula as was used in the corresponding analysis of covariance. In two cases where the curves for boars and sows were nearly the same, they were combined for comparison with barrows.

\section{Live weight}

The regression coefficients $b$ for the live weights as a function of age group are significantly different $(P<0.001)$ and indicate that barrows are about 7 percent heavier than boars and sows at 5 months of age, and are over 50 percent heavier by the 72-month age group (Fig. 17).

Results of the analysis of covariance for the effects of sex, season, area, and age on live weight are summarized in Table 9. Variations in live weight for season and area (Fig. 18) show that boars were 5.3 percent larger than sows in the summer but only 1.4 percent larger in the winter. This is reasonable, since lactating sows are more affected by the poor summer feed conditions than the boars, which fluctuate less in weight and condition (Table 10). Winter weights of boars were 23 percent 


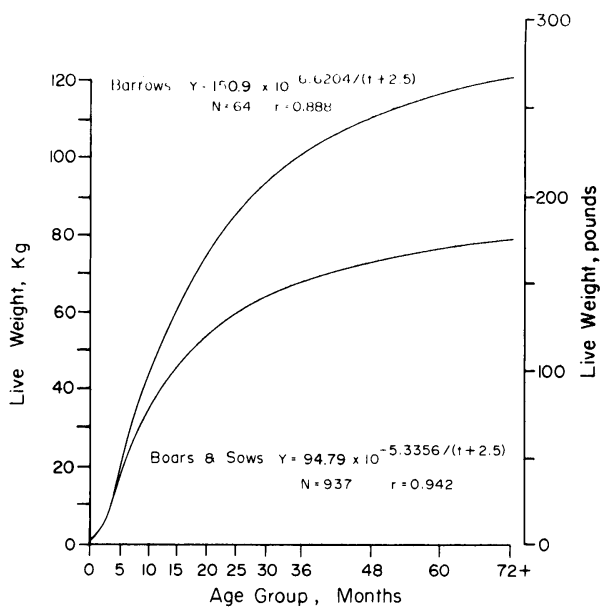

Fig. 17. Growth curves for barrows-and boars and sows combined.

heavier than summer weights, while winter weights of sows were 27 percent heavier than summer weights.

As expected, the pasture hogs made more rapid gains and were significantly $(P<0.001)$ heavier by about 25 percent than the back country hogs. The average back country hog never attains the weight of the same aged pasture animal, the latter maintaining a heavier weight throughout the year.

To determine whether the Dye Creek feral hogs still have the potential of growing as fast as average domestic swine, a female piglet was raised in captivity. Its sole surviving littermate (No. 693) was left with its dam and recaptured at periodic intervals for weighing. The captive piglet (No. 530)

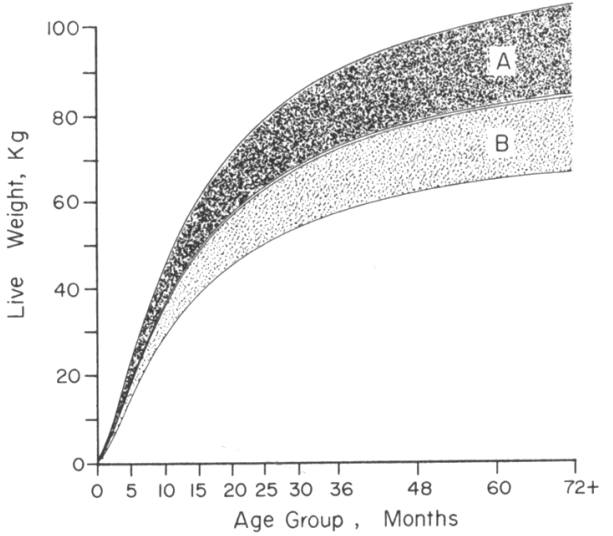

Fig. 18. Variation in mean feral hog live weight by season for boars and sows combined from the pasture area (A) and the foothill area (B). Fitted winter weights are given by the top regression lines for each area, and fitted summer weights are given by the lower lines. The fitted values are derived from an analysis of covariance described in the text.

was raised on a bottle and a standard commercial swine ration. Based on individual growth rates compared with average growth rates for domestic swine and the feral hogs (Fig. 19), it appears that the Dye Creek feral hog is capable of growth comparable to that of typical domestic swine if given adequate food and care. The fact that No. 530 was pregnant with a litter of seven may have caused her relatively slow growth after 5 months of age. Several other piglets of feral stock were raised in captivity and grew at rates similar to that of No. 530. Thus, the relatively slow growth of the feral hogs (less than half

TABLE 9

REGRESSION COEFFICIENTS AND THEIR SIGNIFICANCE FOR SELECTED VARIABLES AFFECTING FERAL HOG LIVE WEIGHT FROM THE ANALYSIS OF COVARIANCE MODEL*

\begin{tabular}{l|c|c|r|r}
\hline \multicolumn{1}{c|}{ Factor } & Coefficient & $\begin{array}{c}\text { Standard } \\
\text { Error }\end{array}$ & $t$ value & $P(1$ tailed $)$ \\
\hline Age & -5.42119 & 0.05470 & 99.1 & $<0.001$ \\
Area & -0.04919 & 0.00349 & 14.1 & $<0.001$ \\
Season & 0.04847 & 0.00411 & 11.8 & $<0.001$ \\
Sex & -0.00700 & 0.00409 & 1.7 & 0.045 \\
Sex $\times$ season & 0.00425 & 0.00408 & 1.0 & 0.159 \\
\hline
\end{tabular}

* The multiple correlation coefficient for the model is 0.959 . 
TABLE 10

CONDITION OF DYE CREEK FERAL HOGS 1968-69 AS INDICATED BY KIDNEY-FAT INDEX (RINEY, 1955) BY SEX AND SEASON

\begin{tabular}{|c|c|c|c|c|}
\hline Sex/season & No. & Mean (range) & $\begin{array}{c}\text { Mean } \\
\text { difference }\end{array}$ & Significance \\
\hline \multicolumn{5}{|l|}{ Boars } \\
\hline Winter & 25 & $27.8(13-50)$ & \multirow{3}{*}{0.8} & \multirow{3}{*}{ N. S. } \\
\hline & & & & \\
\hline Summer & 2 & $27.0(21-33)$ & & \\
\hline \multicolumn{5}{|l|}{ Barrows } \\
\hline Winter & 14 & $105.9(60-188)$ & \multirow{3}{*}{30.6} & \multirow{3}{*}{ N. S. } \\
\hline & & & & \\
\hline Summer & 3 & $75.3(50-80)$ & & \\
\hline \multicolumn{5}{|l|}{ Sows } \\
\hline Winter & 44 & $58.2(5-240)$ & \multirow{3}{*}{31.7} & \multirow{3}{*}{$P<0.01$} \\
\hline & & & & \\
\hline Summer & 18 & $26.5(8-46)$ & & \\
\hline
\end{tabular}

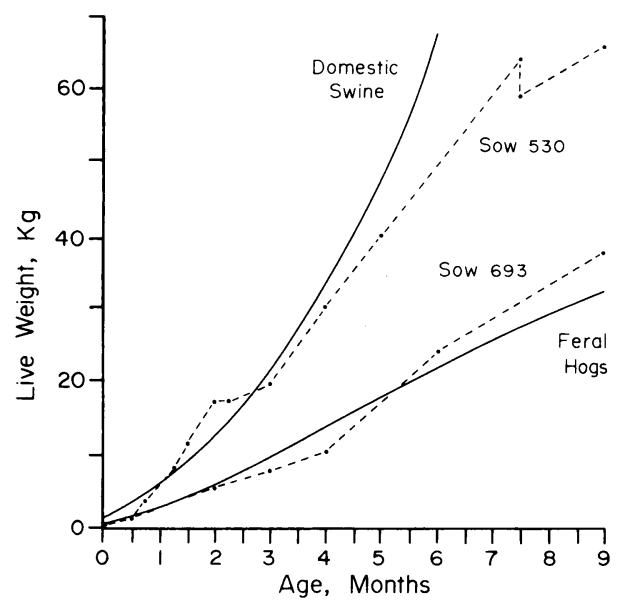

Fig. 19. Growth curves of two sibling feral sows compared with those of domestic swine (Heitman, 1954), and the growth regression for all feral boars and sows where $\mathrm{Y}=94.79 \times$ $10^{-5.3356 /(t+2.5)}$. Sow 530 was captured at 2 weeks of age and raised in captivity. It was weaned at 2 months and farrowed at 7.5 months. Sow 639 remained with its feral mother and was weaned at about 5 months.

that of domestic swine) is more indicative of poor environmental conditions than genetic limitations.

\section{Total length}

Growth curves for each sex, drawn on the fitted points for data on total length, (Fig. 20) indicate that there was considerably less variation in total

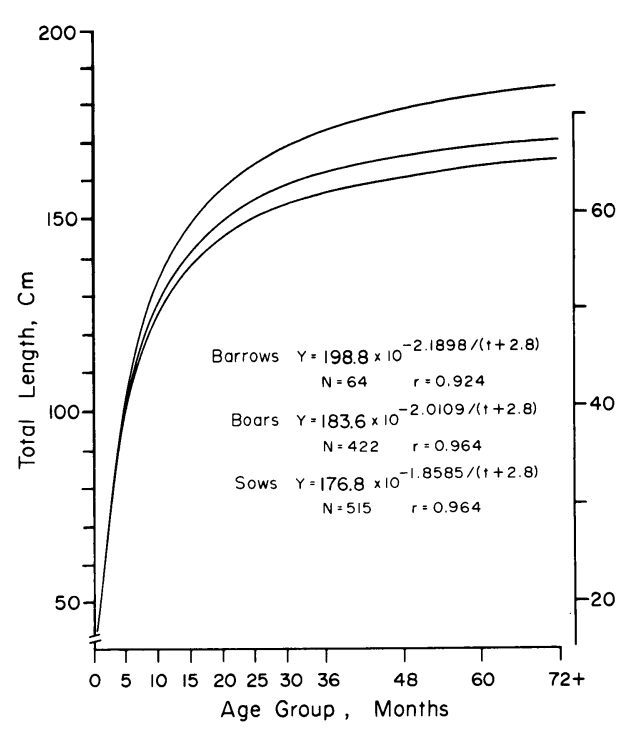

Fig. 20. Comparison of growth in total length of feral barrows, boars, and sows.

length than in live weight. The regression coefficient differences between boars and sows, and barrows and sows were highly significant $(P<0.001)$, and the difference between barrows and boars was considered significant with $P=0.06$.

The analysis of covariance for the effects of sex, season, area, and age on total length (Table 11) shows that area was the most significant factor other 
TABLE 11

REGRESSION COEFFICIENTS AND THEIR SIGNIFICANCE FOR SELECTED VARIABLES AFFECTING FERAL HOG TOTAL LENGTH, FROM THE ANALYSIS OF COVARIANCE MODEL*

\begin{tabular}{l|c|r|r|r}
\hline \multicolumn{1}{c|}{ Variable } & Coefficient & $\begin{array}{c}\text { Standard } \\
\text { Error }\end{array}$ & $t$ value & $P(1$ tailed $)$ \\
\hline Age & -1.95425 & 0.01690 & 115.4 & $<0.001$ \\
Area & -0.01096 & 0.00099 & 11.0 & $<0.001$ \\
Season & 0.00559 & 0.00117 & 4.8 & $<0.001$ \\
Sex & -0.00202 & 0.00093 & 2.2 & 0.014 \\
\hline
\end{tabular}

* The multiple correlation coefficient for the model is 0.968 .

than age, and the pasture hogs were about 5 percent longer than back country hogs. Sexual dimorphism in length was slight but significant.

The effect of season was also highly significant with winter lengths 2.6 percent longer than summer lengths. Since total length is generally nonregressive, this may be explained by: (1) The analysis of covariance model assumes that the regression coefficients for all categories are equal; this assumption was not always met. Because differences at all ages are averaged, a large difference at one end of the age scale, or a nonorthogonal sample can produce results which must be interpreted with caution. Winter feed is better than summer feed; therefore young pigs grow faster in the winter, and are, in fact, longer than young of equal age in the summer. Since young under 12 months of age make up 86 percent of the 937 observations used, the analysis is biased accordingly. (2) The seasonal fluctuation in subcutaneous fat also may have confounded the analysis. Measurements taken on the same adult hog were up to $4 \mathrm{~cm}$ shorter in the summer than those taken the previous winter. This is probably due to the thick layer of fat which rounds the backs of the hogs during the winter, thereby increasing the total length measurement. Although the vertebral column does not shrink during the summer, the fat layer is lost, causing an apparent shrinkage.

\section{Additional measurements}

The remaining six measurements were analyzed in a similar fashion to total weight and total length. The regressions fitted to the data (Fig. 21) indicate significant sexual dimorphism. A detailed discussion of the statistics is given by Barrett (1971).

\section{Discussion}

It is evident that the Dye Creek hogs are capable of growth similar to the average domestic pig, but due to environmental stresses the feral hogs exhibit only about half their potential. The ear and hock mature at roughly 2 years of age. Total length, the head, tail, and shoulder height reach maturity at about 3 years, although they continue to grow slightly throughout life. Girth and especially total weight increase more gradually throughout life, and unlike the other parameters both show distinct negative growth seasonally.

The analyses of covariance can best be summarized with reference to Table 12. Although the $T$ values given are not exactly comparable between the dependent parameters, they give some idea of the relative importance of each independent variable. Age naturally accounts for the most variation. Head length is the best indicator of age and is relatively little affected by environmental conditions. There is relatively little variation due to sex, although there is an 8 percent sexual dimorphism in head length, boars being longer than sows. Barrows are significantly larger than both boars and sows in all respects.

Seasonal variation is directly related to food supply and nutritional status, 

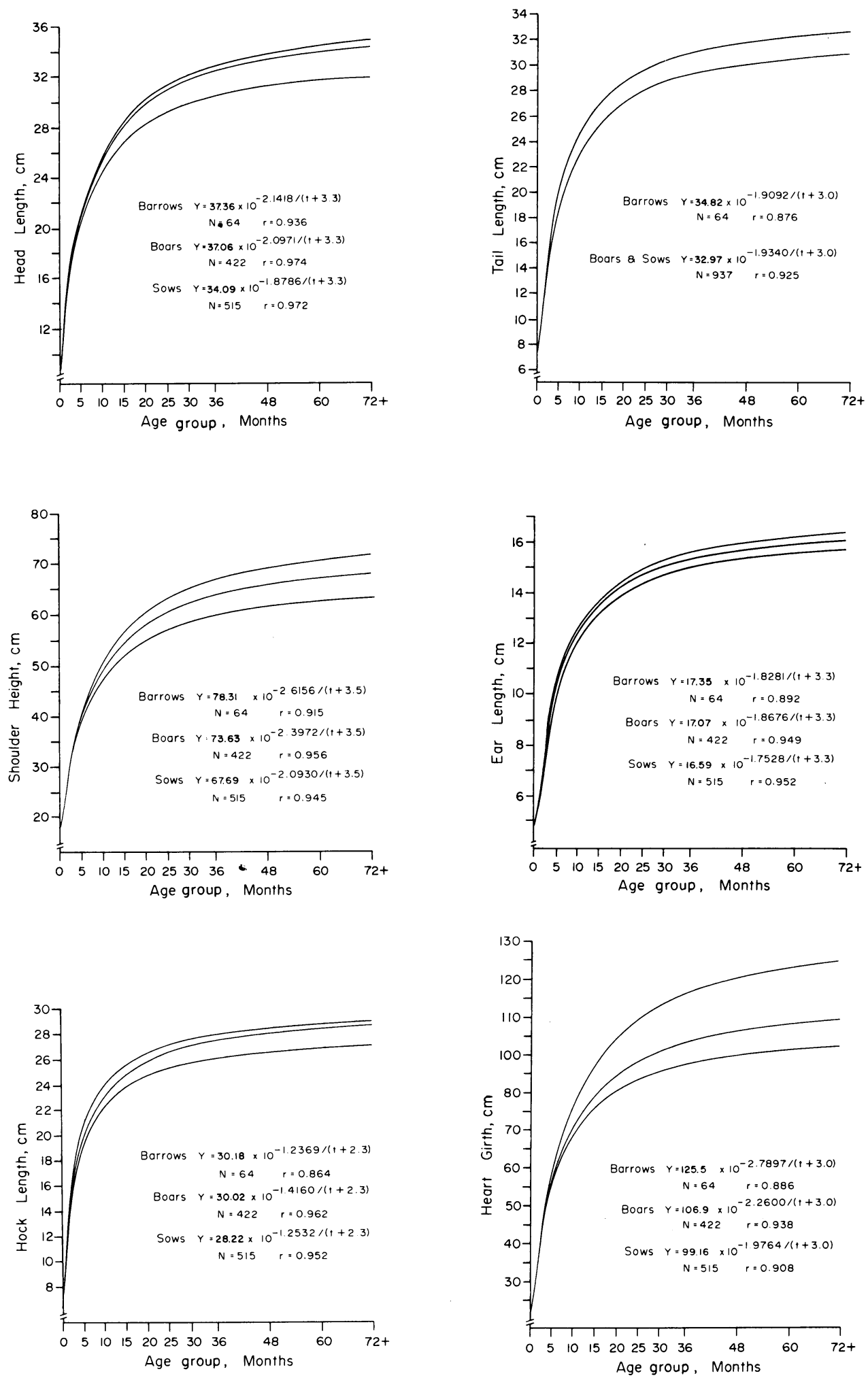

Fig. 21. Growth curves for selected measurements based on 1,001 observations. See text for discussion. 
TABLE 12

T VALUES FOR INDEPENDENT FACTOR COEFFICIENTS DERIVED FROM ANALYSES OF COVARIANCE. ALL VALUES GIVEN ARE SIGNIFICANT $(\mathrm{P}<0.05)$

\begin{tabular}{|c|c|c|c|c|c|}
\hline \multirow{2}{*}{$\begin{array}{l}\text { Dependent } \\
\text { variable }\end{array}$} & \multicolumn{4}{|c|}{$\begin{array}{c}\text { T-values for } \\
\text { independent variables }\end{array}$} & \multirow{2}{*}{$\begin{array}{l}\text { Multiple } \\
\text { correlation } \\
\text { coefficient } \\
\text { squared }\end{array}$} \\
\hline & Age & Sex & Season & Area & \\
\hline Total weight & 99.1 & 1.7 & 11.8 & 14.1 & 0.920 \\
\hline Total length & 115.4 & 2.2 & 4.8 & 11.0 & 0.937 \\
\hline Head length & 125.8 & 9.6 & 5.9 & 5.8 & 0.949 \\
\hline Tail length & 75.2 & N.S. & N.S. & 5.9 & 0.863 \\
\hline Shoulder height & 99.7 & 5.2 & 11.0 & 6.4 & 0.922 \\
\hline Ear length & 96.4 & 1.8 & 3.6 & 9.4 & 0.914 \\
\hline Hock length & 99.8 & 7.0 & 2.5 & 7.3 & 0.920 \\
\hline Heart girth & 81.4 & 3.8 & 11.8 & 9.4 & 0.889 \\
\hline
\end{tabular}

the hogs (especially sows) growing fat in the autumn and winter, and thin in the spring and summer. Season primarily influenced total weight and girth. However, the highly significant $T$ values for the remaining parameters indicate that young pigs grow faster in the winter than in the summer.

Of the four independent factors, area was second only to age in accounting for variation in most parameters measured, and it significantly affected every parameter. There is little doubt that the availability of green, protein-rich pasture grasses and legumes not only increased the growth rate of young pasture pigs during the summer, but had a significant carry-over effect throughout the remainder of the year and even the rest of the hogs' lives.

The multiple coefficients of determination (Table 12) suggest that 86 to 95 percent of the observed variation in measurements was explained by the models used. However, it must be stressed that the accuracy of the statistics is no better than the data used. The method of determining age in older individuals is particularly suspect. Some hogs were used for more than one multivariate observation, and such data are not strictly independent. The concentration of observations in the early age groups obviously biased the analysis in several respects. However, even with these reservations, the method was useful in this case. The significance of the area effect was so great in all cases that it is undoubtedly real. Furthermore even though the growth curves presented do not fit the data for very young and very old hogs as well as might be desired, the regression models were very useful in presenting the great mass of growth data in a standardized and concise form.

\section{REPRODUCTION}

Particular attention is directed to differences in reproductive pattern between pasture and foothill animals as determined from an analysis of $71 \mathrm{fe}$ male reproductive tracts collected throughout the year. In addition, feral hog data are compared with the reproductive patterns of domestic swine and wild boar.

The main economic function of the domestic sow is to produce young which will reach market age. Consequently, much research effort has gone into maximizing this productivity. Duncan and Lodge (1960), Day (1962), Fraser (1968), and Sadleir (1969) all provided good reviews of the voluminous literature on swine reproduction. The last two authors compared the reproductive biology of swine with that of other ungulates and other mammals, respectively. 


\section{Puberty}

The domestic boar produces primary spermatocytes at about 3 months of age, and mature sperm by 6 months of age. However, domestic boars generally are not used for breeding before they are 9 months old (Day, 1962). At Dye Creek, feral boars about 6 months old often attempted to breed. Because of their subordinance to the older boars and their small size relative to that of the adult sow, they were rarely successful. Feral boars were normally 12 to 18 months old before they took a significant part in breeding activities.

The domestic sow's ovaries normally produce Graafian follicles at an age of 3 to 4 months. There may be several "false estruses" before actual puberty. The first successful breeding usually occurs at 6 to 7 months of age, but the range is known to be from 3 to 13 months. The time at first breeding is influenced by severe restriction in energy intake and by excessive fatness (Duncan and Lodge, 1960).

The range in age at puberty was 6 to 8 months for nine feral sows of known age in the pasture area. In the back country area the few data available indicate that puberty occurred between 8 and 10 months. Three back country sows were known to have had their first litters when 14 months of age. The figures given for the pasture area hogs are comparable to those for domestic swine, but the severely restricted diet of the back country hogs apparently increased the age of puberty by about 2 months. Birth date may also have had some effect. A few observations suggested that sows born in the summer first bred at an older age than those born in the winter.

European wild boar generally first breed as yearlings (18 to 21 months) (Sludskii, 1956; Haber, 1969). However, in good mast years a small proportion of young sows may breed at 8 to 10 months of age (Oloff, 1951). Domestic $\times$ wild boar hybrids may be in- termediate; a captive hybrid sow from Monterey County, California, first bred at 12 months, although it was in good condition and had constant opportunity to breed earlier.

\section{Estrus and breeding behavior}

Domestic swine are polyestrous. Once breeding age is reached, estrus occurs every 21 (18 to 24 days, and the outward signs persist for 1 to 5 days. A sow's first estrus lasts only about a day but this increases to 2 to 3 days in adult sows. During estrus the vulva becomes swollen and the sow stands to back pressure or mounting. A postpartum estrus is exhibited 2 to 4 days after farrowing, but is usually infertile. Lactation inhibits estrus until about 2 months postpartum. However, removal of the young, even for a period each day, will stimulate the onset of estrus. If the young are removed immediately after farrowing, estrus can be induced within 2 to 4 weeks. If suckling continues for 6 to 8 weeks, estrus will recommence about 4 (3 to 10 ) days after the young are removed (Duncan and Lodge, 1960; Day, 1962).

I watched four different estrous sows for several hours each. When a sow came into estrus, as many as 10 boars gathered around her for about 2 days. When the sow began standing for breeding she was bred as often as every 10 minutes throughout the estrous period. By the second day she was exhausted from being pushed around and from a lack of food. Unless the weather was very hot or very cold, breeding took place continuously, day and night.

There was much activity, and much fighting if several boars of equal dominance were present. Sows did not get much chance to overtly stimulate the boars. The sow was courted so intensely by so many boars, even before she was ready to stand, that her main reaction was just to try and maintain her position. By the end of 2 days, however, she often was too exhausted to do that. 
Breeding activity was a jumbled combination of courtship, male fighting, and breeding. Boars courted by "nuzzling" the flank, belly, and perineal regions of the sow, and by uttering a "chant de cour" (Burger, 1952; Madden, 1962). They also chomped their jaws and salivated. Both sexes urinated frequently which seemed to have a stimulating effect, as noted by other authors (Quinto, 1957; Eibl and Wettke, 1964). The boar's preputial fluid which contains "muskone" (Dutt et al., 1959) is the pheromone excreted while urinating (Signoret and Du Mesnil du Buisson, 1962).

Most contests between rival boars were settled by a display or a charge by the larger and older boar. The charge usually caused the subordinate boar to back away squealing. Boars displayed by facing cach other head to shoulder with erect manes, so as to present a large broadside silhouette and open mouth and tusks to the competitor. There was much loud roaring and coughing, and actual combat occasionally occurred. Boars fought by charging sideways and slashing the opponent with an upward thrust of the tusks. After a charge or two, the animals would again pair off and display, with upraised heads and open mouths, a pattern also seen in wild boar (Beuerle, 1975).

The largest, oldest boar bred first unless it was so involved with competitors that a younger boar reached the sow first. After breeding, a dominant boar would lie down nearby while subordinate boars bred. Then after 15 to 30 min., he would return to breed again. This pattern continued as long as the sow would stand. In one instance, boars attempted to breed a sow which was too exhausted to stand.

In the confusion there was much homosexual activity, especially by the young males, which often attempted to mount the sow's head or the boar breedat the moment. In one instance, four boars mounted each other at once, form- ing a train of five boars behind the sow. There was obviously little chance for normal sows to go unbred, and most litters probably had multiple fathers.

\section{Gestation and parturition}

The gestation period in a captive feral sow was 116 to 118 days, close to the average gestation period of 114 (98 to 124) days for domestic swine (Ensminger, 1961:146). The gestation period for European wild boar is slightly longer than for domestic swine, ranging from 110 to 140 days (Kenneth and Ritchie, 1953:19; Asdell, 1964:541).

Shortly before farrowing, the feral sow left the family group to build a nest in a heavily vegetated, secluded spot. Nests could be simply a large bed rooted into the soil, but usually they were haphazardly lined with grasses, leaves, and other vegetation. I never found a nest as elaborate as the shelters described by Nichols (1962), Medway (1963), Gundlach (1968) or Diong (1973). I watched one sow carry several mouthfuls of dry grass to her nest, but I never observed parturition in the wild. Sows remained fairly close to the nest for at least a week after farrowing. Then as the young grew and could travel better, they began to follow the sow as she fed farther and farther from the nest.

\section{Frequency and season of breeding}

The Dye Creek sows are polyestrous, averaging two litters per year. I found no indication that anestrous periods occurred for more than a month or two after lactation. This was most commonly observed in sows losing their litters within the first month postpartum. Three tagged sows never reproduced in 2 years. They all were very fat and may have had reproductive disorders, but no autopsies were made to check this. All 71 adult sows autopsied throughout the year either were pregnant or lactating.

If a sow did not lose her entire litter, 
she normally suckled for 3 to 4 months; one sow weaned a litter at 2.5 months, and another suckled a single young for 5 months. Estrus normally occurred in lactating sows 2 to 3 months postpartum whether they were drying up or not. I observed several cases of sows breeding while lactating. One pasture sow in good condition was bred only 1 month postpartum, although she suckled her litter until just 1 month before the next litter was born. On the other hand, foothill sows in very poor condition after suckling a litter occa-

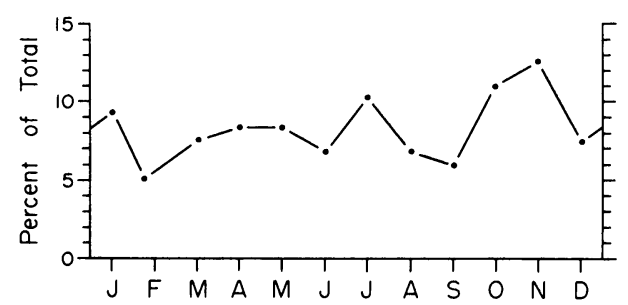

Fig. 22. Number of feral hog litters farrowed, presented as the percentage of total recorded farrowings. Two consecutive farrowing dates for 59 sows were available for a total sample of 118 dates.

sionally did not breed again until 5 months postpartum. Thus, nutritional condition of the sow apparently can affect the frequency of breeding, even when lactation extends for the normal period.

To clarify the Dye Creek situation, I plotted two successive farrowing dates for 59 sows that were intensively studied in the Kingsley sub-unit of the study area. The 118 farrowing dates represent about 50 percent of all litters dropped in the subunit between July, 1967, and November, 1969. There was no definite peak of activity, but there were two small rises, one in July and one in November (Fig. 22). This correlates with observations that breeding increased in midspring and the late summer. These periods are close to the "natural" breeding seasons for domestic swine which, according to Ensminger $(1961: 146)$, occur in the early sum- mer and late autumn. Most sows in the corn belt region of the United States farrow in April and in September (Smith, 1952:17).

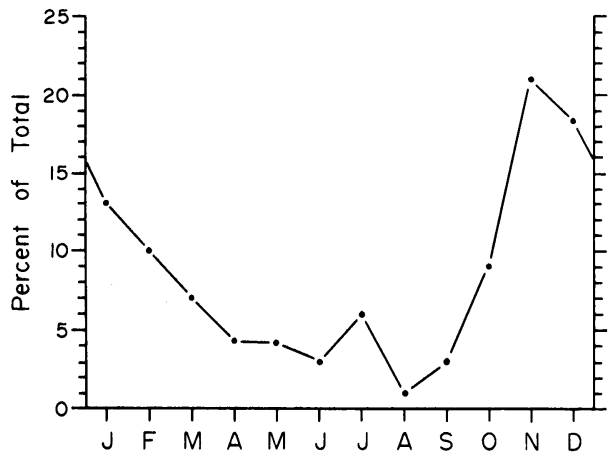

Fig. 23. Estimated month of birth of 360 surviving feral hogs 4-16 months of age as of September 1969.

Other data also support the possibility of two peak breeding periods. A total of 360 hogs, between the ages of 4 and 16 months as of September, 1969, were back-aged to determine their month of birth. These hogs were trapped all over the study area. Births by month as percentages of the total sample (Fig. 23) show peaks in July and November. The relatively low July peak is a result of the poor survival of young born in the summer.

The two intervals between farrowing peaks (Figs. 22, 23), one 5 months and one 7 months, can be related to nutritional status of the sows. During the summer many if not most of the sows lost all their young soon after farrowing. They bred within a month and thus were ready to farrow again by November if they lost their litter in July. Few litters are lost entirely during the winter, and since most sows did not come into estrus until after 3 months of lactation, the interval between litters was about 7 months. Accidents and acorn crop failures could alter this pattern, and individual sows did not necessarily keep a 7 month 5 month pattern. The above information is for relatively good acorn years, and an acorn crop failure 
could cause a considerable shift in many aspects of the reproductive pattern.

Wild boar in Europe normally breed only once a year, and most young are born in March or April (Sludskii, 1956; Haber, 1961). However, they are capable of producing two litters per year under zoo conditions (Ackernecht, 1950; Zuckerman, 1953; Steinbacher, 1954), and during years with excellent mast crops (Oloff, 1951; Mauget, 1972). European wild boar may cease breeding altogether in very poor mast years (Oloff, 1951; Cabon, 1958a; Henry, 1966). In contrast, subspecies of wild boar in India and Southeast Asia breed twice a year (Blanford, 1888-1891; Hoogerwerf, 1970:345; Diong, 1973).

Domestication has placed strong emphasis on the polyetrous habit, and other studies of feral hog populations are in agreement that this trait is not readily lost (Wodzicki, 1950; Nichols, 1962). Even in the winter of 1967-1968 when the Dye Creek acorn crop was poor, apparently all sows attempted to produce litters. In terms of reproductive efficiency, the feral hog appears less adapted than the European wild boar to the seasonal food conditions generally found in temperate regions.

\section{Litter size}

Modern breeds of domestic swine produce from 7 to 24 young per litter (Duncan and Lodge, 1960; Epstein, 1969; Wrathall, 1971). Domestic sows produce approximately 50 Graafian follicles (over $3 \mathrm{~mm}$ diameter) and 20 corpora lutea per estrus; thus, given a mean litter size of 14 young, they normally lose 60 percent of potential ova and exhibit an intrauterine mortality of nearly 40 percent (Duncan and Lodge, 1960). About two-thirds of the intrauterine losses occur during the first month of pregnancy and are related to implantation failure (Wrathall, 1971).

Reproductive tracts of 71 Dye Creek feral sows were analyzed. Ovaries were sliced into $1-2-\mathrm{mm}$ sections with a razor blade after preservation in 10 percent formalin. The number of Graafian follicles over $3 \mathrm{~mm}$ and the number of corpora lutea of pregnancy were recorded. Fetuses were counted and measured from crown to rump. Mean age (mean 77, range 25 to 118 days) of each litter was determined from mean crown-rump lengths (Warwick, 1928; Ullrey et al., 1965; Henry, 1968).

Litter size averaged 5.6 (one to 10) live fetuses per sow. This is very close to the 5.4 fetuses per sow reported for feral sows in Hawaii (Nichols, 1962). The mean number of developing follicles was 23 (eight to 35), and the mean ovulation rate as indicated by the number of corpora lutea was 8.5 (four to 15) per pregnancy. Thus, follicle losses were 68 percent before ovulation, and intrauterine losses were 34 percent. Only a quarter of this intrauterine mortality was accounted for by atrophic fetuses dying during the last half of pregnancy.

The European wild boar reportedly has mean litter sizes of four to six young, but individual litters may range up to 13 (Oloff, 1951; Sludskii, 1956:54; Asdell, 1964; Henry, 1966; Mauget, 1972; Pine and Gerdes, 1973). European wild boar apparently produce about 25 follicles per estrus (Kappeli, 1908), only half that produced by domestic swine, but similar to the number for feral hogs. They produce a mean of five to six corpora lutea per pregnancy (Boye, 1956; Mauget, 1972), which is significantly fewer than feral hogs or domestic swine. Thus, the European wild boar exhibits a potential ova loss of nearly 80 percent but an intrauterine mortality of less than 20 percent.

\section{Variation in litter size}

There is variation in litter size within a given breed of domestic swine with parity and nutritive status of the sow (Anderson and Melampy, 1972). He- 


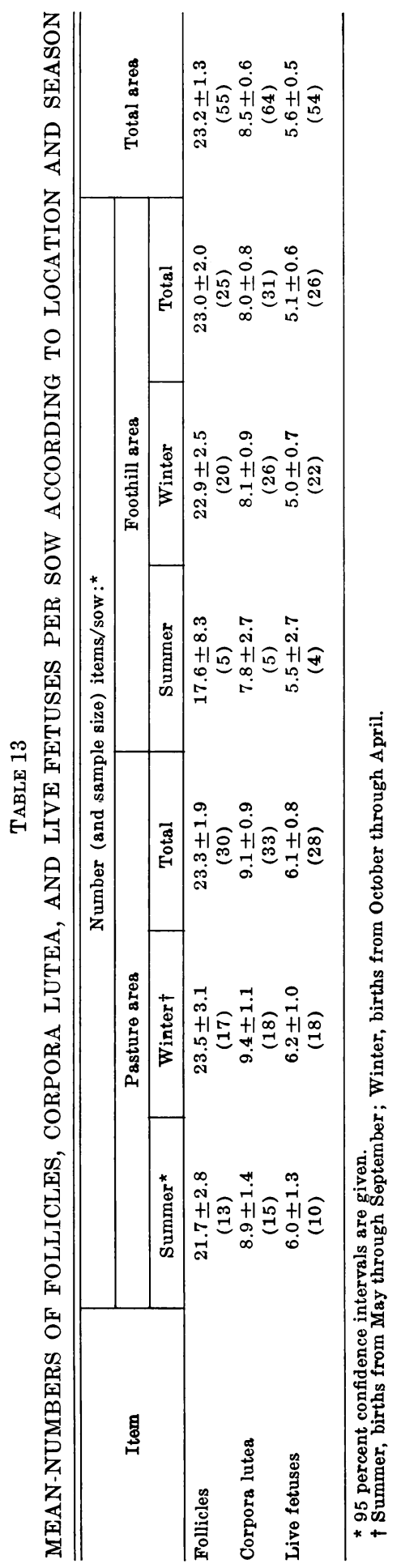

reditary defects and disease will not be considered here. The litter size of domestic sows increases with age and parity until the fifth or sixth litter (Day, 1962). Beyond this stage, fecundity continues to increase, but prenatal mortality increases faster, resulting in smaller litter size. Sows fed diets very high or very low in digestible energy have reduced litter sizes. Also, diets deficient in individual nutrients, particularly protein, cause reduced litter sizes. Both the quality and the quantity of the protein is important, indicating that it is certain amino acids which are essential, not just protein in general (Duncan and Lodge, 1960; Moustgaard, 1969:489).

The same independent factors of age, season, and area were used in analyzing the variation in litter size as were used in analyzing variation in growth. First, the effect of the sow's age was considered for the data within each area. The relatively poor nutritional status of the foothill sows masked the effect of age on follicle number and number of live fetuses, but corpora lutea number increased with age. In the pasture area, where better nutrition allowed a fuller expression of potential productivity, fetus number increased with age from 5.3 in gilts to 8.7 in the 4 - to 5 -year age group. As in the foothill area, follicle number remained constant while the number of corpora lutea increased with age. However, none of the differences found between age groups was statistically significant.

The seasonal variation was considered for each area. The mean follicle number was 8 to 30 percent higher, and the mean corpora lutea number was 4 to 5 percent higher in the winter samples (Table 13). On the other hand, winter fetus counts averaged 5.3 percent lower than summer counts for both areas combined. Using Student's $t$ test, none of the seasonal differences was significant at the $\mathrm{P}=0.05$ level.

Comparing the two areas without con- 
sideration of age or season, sows from both areas averaged 23 developing follicles (Table 13). The pasture sows averaged 9.1 , and the back country sows averaged 8.0 corpora lutea per pregnancy-a 14 percent difference which is significant in a 1-tailed test $(\mathrm{P}<0.05)$. The pasture sows averaged 6.1 , and the back country sows averaged 5.6 fetuses per litter-a 20 percent difference, highly significant in a 1-tailed test ( $P$ $<0.01)$.

\section{Discussion}

Apparently the average number of primary and secondary follicles produced is fairly stable for this population of hogs. If this parameter is definitive for a given population or breed of pigs, the Dye Creek feral hog has a lower potential fecundity than modern domestic swine. This is reasonable since swine of the late 1800 s had a lower productivity than do modern breeds (Duncan and Lodge, 1960). Another possibility is that selection is occurring for a reduced fecundity as a means of improving the reproductive efficiency of the population. A high reproductive rate is of little value if it results in the death of sows that attempt to suckle young under conditions of very limited food supplies .

The difference in food habits and nutritional status between the pasture and foothill hogs produced a significant difference in mean litter size. In addition, limited data suggest that pasture hogs breed earlier and more frequently than back country hogs. This substantiates the hypothesis that use of summer irrigated pastures by the pasture hogs results not only in more rapid growth of individuals but in greater productivity of sows.

These results agree with the wellknown fact that improved nutrition produces increased growth and reproduction in swine. The data presented document this fact in a wild pig population and provide specific estimates of reproductive success for a fairly well-defined pattern of food habits. Despite the variation in their food supply, the Dye Creek feral hogs maintain the polyestrous habit of domestic swine. Possibly some feral sows cease to breed in poor mast years, but in this respect the feral hog is not as sensitive to its environment as is the European wild boar.

\section{MORTALITY}

Of the seven categories of feral pig mortality, accidents, starvation, and predation primarily affect piglets under 6 months of age. Adult hog losses are largely due to hunting, but parasites, diseases, and tooth deterioration take some individuals.

\section{Accidents and injuries}

Accidents, including stillbirths, are the most important cause of piglet mortality in domestic swine. Suffocation during birth causes a 4 to 7 percent loss (Duncan and Lodge, 1960:39), and crushing is the major cause of accidental deaths (Smith, 1952:69). Similar losses probably were sustained by feral piglets. I found six dead young in nests vacated by feral sows. These young were less than 2 weeks old and all had broken bones and apparently had been crushed to death. In domestic swine, accidental losses tend to increase with increased litter size and with increased age of the sow (Fraser, 1968: 143). The greater the number of young, the harder it is for a sow to move or lie down in the nest without injuring a piglet.

When the piglets begin to venture from the nest at 1 to 2 weeks of age, the chance of accidental death by becoming separated from the sow increases. Twice I observed single piglets 
left behind by the sow and the rest of the litter. If the sow rejoins a larger group of hogs there is a chance of piglet losses due to careless or aggressive behavior of other hogs, particularly boars. I observed two young piglets trampled by several adult hogs when the latter were surprised in their shelter. Boars occasionally knocked piglets aside if the piglets got in their way. I observed one case in which a boar killed a piglet by tusking it in the abdomen; the boar was in a trap and excited at the time. Domestic swine are known to be cannibalistic in some cases (Fraser, 1968:130), but I never observed this in the feral hogs. There was evidence of hogs eating hog carrion, however.

During the summer, many piglets got foxtails in their eyes while walking through dry grass. The most common were red brome and fescue florets. Two piglets' eyes were so damaged that the animals were blinded. One of these piglets was observed to follow its mother and suckle although blind, but when weaned, this piglet disappeared and presumably died.

Another hazard was porcupine Erethizon dorsatum quills. A 5-month old hog was trapped which had over 100 quills in its face and mouth. Porcupine quills occurred in the stomach, liver, intestines and body walls of 6 adult hogs autopsied. The quills may have entered during feeding on porcupine carrion and did not seem to be causing severe damage to the animals.

Wounds were commonly found on boars and occasionally on sows. Since the feral hog breeds throughout the year, boars are continually fighting. Most wounds occurred on the boar's shield and usually were minor cuts. However, a number of facial cuts and punctures were found. These wounds normally formed abscesses, and during the summer commonly became infested with maggots. Several of the boar skulls collected showed signs of wounds on the frontal and parietal bones, which had been gouged and even penetrated. Although tusk wounds were common, they usually healed rapidly. Only three boars were observed to be in poor condition because of their wounds; however, one of these would probably have succumbed if not shot.

Two sows were observed that had been tusked by boars. In both cases the tusks had inflicted a deep, 10 to $15-\mathrm{cm}$ gash on the belly near the flank. In one case the wound had healed completely by the time I recaptured the sow a month later. Such wounds might be inflicted when boars "nuzzle" the sows during breeding activities, or they might result from fighting over a food item.

\section{Starvation}

During summer and in winters with poor mast production, many piglets died of starvation or of starvation-induced causes. A sow will produce only as much milk as her least abundant nutrient reserve will allow. The quality of a sow's milk is little affected by nutritional deficiencies, although its composition changes slightly over the lactation period (Elsley, 1971). If a sow cannot obtain sufficient amounts of the necessary nutrients, she will limit her milk production by drying up one or more teats (Duncan and Lodge, 1960).

Piglets using the forward teats grow faster than piglets using the hind teats (Fraser, 1968). The larger piglets tend to dominate the forward teats, and a "teat order" is developed soon after birth. This order tends to reduce aggressive behavior by the piglets and speeds sucking by all littermates. After sucking, piglets normally remain attached to their teat while resting. Increased aggressive behavior of littermates and increased sow movements cause increased disruption of the teat order. Displaced piglets become disoriented, are more likely to be crushed, and 
are more susceptible to exhaustion and starvation (Fraser, 1968:132).

Dominance in piglets is a function of weight and strength. I raised two very young piglets on a bottle. First, I allowed one piglet to have all the food it wanted, but limited the food of the other piglet. The first piglet became larger and stronger and always was able to dominate the bottle when offered to the two piglets together. A week later, $I$ reversed the feeding schedule, and soon the second piglet was larger and stronger than the first, and was able to dominate the bottle.

I observed the sequence of events during the lactation periods of two sows that lost young during the summer. One sow (No. 377) was first observed with seven very young piglets. She was lactating on all 12 teats but within a week had lost considerable weight and was lactating on only six of 12 teats. One piglet was obviously a runt and disappeared the next day leaving one piglet per functioning teat. One week later, and approximately 1 month after farrowing, the sow was in very poor condition and was lactating on only five teats for six young. Two days later the smallest littermate disappeared and its partly eaten carcass was found in the vicinity. The sow successfully raised the other piglets and finally dried up the last five teats 3.5 months after farrowing. During the lactation period, she lost nearly 50 percent of her prefarrowing weight.

A yearling sow farrowed at least five young in her first litter during the summer of 1969. Although most gilts lost their litters soon after farrowing, especially during the summer, this gilt only lost two young in the first 2 weeks. About a month after farrowing, she dried up on two of the remaining functional teats and promptly two of her three young disappeared. She succeeded in raising the remaining piglet to weaning age.

One other exceptional case was ob- served in which an old sow (No. 201) dried up three of six functioning teats and kept only three young. A gilt (No. 499) which was the sow's daughter had just lost her entire litter. Before drying up, she adopted the older sow's three abandoned young and successfully raised them to weaning age, becoming extremely thin in the process.

Starvation is probably the major cause of feral piglet mortality. During summer, most lactating sows are in very poor condition (Table 10) and piglet mortality is greatest (Fig. 23). Starvation is also a major factor predisposing piglets to accidents and predation and would become increasingly important during a period of poor mast crops.

Protein probably is the nutrient most often restricting milk production of Dye Creek sows (Fig. 15). Duncan and Lodge (1960) found that domestic sows on diets with less than 15 percent crude protein lost 17 to 18 percent of their young. The diet of the foothill hogs contained only half this amount $(7.3 \%)$. Most of this was of vegetable origin, which may be lacking in some essential amino acids. Such an imbalance in amino acids may be partly compensated for by products of microbial fermentation in the alimentary tract.

I observed a few cases of communal nursing within family groups where two or three sows were nursing young of the same age. In one case, I watched one of three lactating sows babysit the entire group of piglets for several hours, while the other two sows were elsewhere. Another day, a second sow was watching over all the young. Sayler (1969) stated that communal nursing by laboratory mice increased the growth rate of the young mice, even when the ratio of mothers to young was the same as for young raised by a single mother.

Most piglets are weaned by 4 months of age. Between then and 6 months of age, the young hog must make the transition from a milk-supplemented diet rich in protein to a diet low in protein. 
If the piglet is weaned during the summer in the foothills its postweaning diet may provide only a fourth of the optimum intake of protein (Table 5, Fig. 15). Many recently weaned hogs in the foothills stopped growing for a month or more. Starvation or starvation-induced mortality undoubtedly occurred during this critical period. However, if a feral hog reached 6 months of age, its chance of surviving to reproduce appeared good.

Starvation may sometimes occur in adult sows in the later stages of lactation during the summer. I observed two cases in which lactating sows were so weak they could hardly move. They or their young were never seen again.

\section{Predation}

Although wild pigs are important prey of large felids in other areas (e.g. Rakov, 1970; Hoogerwerf, 1970), humans appeared to be the only predators of adult feral hogs in the study area. Potential predators of piglets included coyotes Canis latrans, bobcats Lynx rufus, and golden eagles Aquila chrysaetos. Mountain lions Felis concolor do not inhabit the Dye Creek Ranch. The coyote was the only predator present in numbers great enough to cause significant piglet mortality. Therefore, 1,042 coyote scats were analyzed for the frequency of occurrence of food items. Feral hog remains were found in 12.7 percent of all the scats analyzed, and piglet remains accounted for 95 percent of all the hog material (Barrett, 1971). The remaining 5 percent consisted of mummified or maggot-ridden adult hog remains-suggesting it was eaten as carrion.

Many of the coyote scats contained mummified piglet hide. This, and the fact that $I$ found a number of piglet carcasses in nests and one simply lying along a creek indicates that there was a quantity of piglet carrion available. I suggest that a large portion of the piglets eaten were not killed by coyotes, and that piglets which were killed probably were predisposed by starvation or accidental abandonment. More data are needed to substantiate this.

I expected that piglets would comprise a larger portion of the coyote's summer-fall diet than its winter-spring diet because the hog is the only resident large mammal during the summer, and piglet losses are highest during this season. However, the proportion of hog remains in the scats was relatively constant throughout the year, which further suggests that predation is not the primary cause of piglet mortality.

\section{Parasites}

No detailed study was made of feral hog parasites because they did not appear to be a major mortality factor. All feral hogs examined, even those as young as 2 weeks old, harbored light to heavy infestations of the common hog louse Hematopinus suis. Most hogs had fewer than 100 lice and these did not seem to be a problem to the adult animals. I found a few young piglets suffering from heavy infestation of lice.

Ticks Dermacentor sp. were rarely discovered on the hogs, and I never found more than six ticks on one animal. Ticks were usually attached to the inner flank region.

All the internal organs of 65 adult hogs were dissected, and a gross examination was made for internal parasites or parasitic lesions. The most common internal parasite found was the swine lungworm Metastrongylus sp. Of the hogs examined, 60 percent harbored lungworms or showed lesions from this parasite. Seventy-four percent of the samples from the pasture area and 45 percent of the samples from the foothill area had lungworm, probably because the pasture hogs consumed more earthworms than the foothill hogs-earthworms being the intermediate host for swine lungworm (Dunne, 1970:718). Most infestations were light, but in a 
few cases as much as a third of the lung was affected by this parasite.

Six of the hogs autopsied had one or more thin-necked bladder worms Taenia hydatigena attached to the liver, intestines, or fallopian tubes. The coyote probably is the intermediate host for this parasite. I found one case in which a hog had eaten a coyote scat; such behavior would increase the hogs' chances of becoming infested with bladder worms.

One hydatid cyst Echinococcus granulosis about $20 \mathrm{~mm}$ in diameter, was found in the liver of a hog. The coyote probably also is the principal intermediate host for this parasite.

I found two cases of very light infestations of the large intestinal roundworm Ascaris lumbricoides. I also noted a few cases in which the hog's liver had several small white scars which possibly were produced by migrating ascarid larvae. This parasite probably is uncommon because the hogs range over large, seasonally dry areas, thereby reducing the chances for reinfection.

None of the smaller roundworms including Trichina was ever located, but I did not attempt to make a thorough examination for them. No cases were found in which parasite loads were so great that they could have been an important mortality factor, but it is possible that parasites become a significant predisposing factor in times of high hog densities and poor acorn crops.

\section{Diseases}

No signs of any of the common swine diseases (Anthony and Lewis, 1961; Dunne, 1970) were observed in the feral hogs during this study. In cooperation with the California State Department of Agriculture, blood samples were collected from 97 feral hogs. These samples were tested for brucellosis with a standard card test by the local state veterinarian. All of the samples proved negative. Eighteen percent of feral hogs sampled in South Carolina showed positive reactions for brucellosis (Wood et al., 1976).

Wild pigs have been known to carry bovine tuberculosis in other parts of California (Allison, 1967:15), but no sign of this disease was noted in the feral hogs autopsied. The pulmonary lymph nodes of a barrow with septicemia were sent to the State Department of Agriculture for testing and proved negative for tuberculosis.

Two possible cases of infectious atrophic rhinitis were observed in animals kept in the preserve's breeding pens. One European sow from Monterey County had a swollen and bent nose, but otherwise appeared healthy. A young male hybrid which also developed a bent nose, may have contracted the disease from the sow. Both individuals were killed. Neither was ever released from the pens, and no signs of atrophic rhinitis were ever observed in freeranging feral hogs.

\section{Tooth deterioration}

Tooth deterioration apparently was the most important cause of death from old age. All hogs examined which were over 4 years old had one or more periodontal abscesses. Deterioration begins as erosion of the teeth themselves, or as a result of hard materials such as twigs and acorn hulls becoming impacted under the gum. These areas then fill with decaying food. This eventually develops into an infection which may extend well into the jaw bone. In one skull, an abscess had eroded the base of the cranium in the vicinity of the upper third molar and apparently reached the brain cavity before the animal died. If large abscesses contaminate the blood, the animal may die of a generalized septicemia. One old barrow was shot that had abscesses containing pyogenic bacteria throughout the bone marrow and in several joints. This situation probably resulted from deterioration of the teeth and the spread of bacteria from large abscesses in the animal's jaw. 


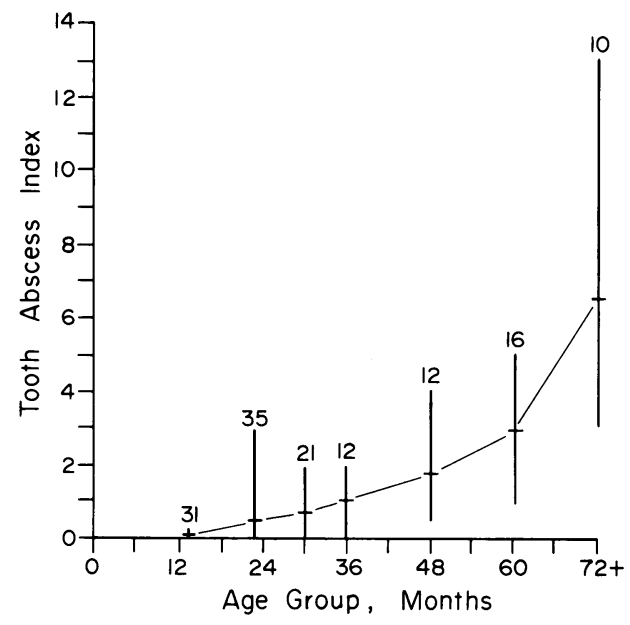

Fig. 24. The relationship of the tooth abscess index to age group for the Dye Creek feral hog, based on 137 skulls collected from hunter kills and natural mortalities. Horizontal bars indicate the mean and vertical bars indicate the range for each age group. Sample size is given above each range line.

To obtain an idea of the prevalence of tooth abscesses in the population, 137 skulls collected from hunter kills and natural mortalities were examined. A tooth abscess index was developed for comparative purposes. The number of teeth affected by abscesses were counted in both jaws. Each tooth involved was given a value of 1 if still present and a value of 2 if missing as a result of the abscess. There was no significant difference between the number of abscesses in the upper and lower jaws. The points for both jaws were totaled and divided by 2 to give the index value in terms of a single jaw.

No abscesses were found in skulls under 9 months old (Fig. 24). From that age, the number of abscesses increased slowly until the 48-month age group. Hogs 5 years old and older all had one or more abscesses and often had deformed jaws or teeth missing. Normally, the first molars were the first teeth lost. The most severe abscesses usually developed between the first and second molars then spread to the third molars. Loss of these molars obviously impaired a hog's ability to feed. Tooth deterioration and the factors influencing it (Sognnaes, 1963; Jump and Weaver, 1966) need further study.

\section{Discussion}

Of the causes of mortality discussed, starvation and accidents or predation predisposed by starvation appear to be primarily responsible for piglet losses. A relatively low-energy diet compounded by a shortage of protein, especially high quality protein, causes lactating sows to restrict milk production. The drying up of one or more teats results in the starvation of a corresponding number of subdominant piglets, unless they can find a foster sow. Piglet losses are greatest during the dry summer months, particularly in the foothills. Presumably a similar process occurs in years of acorn crop failure. Predation losses probably are minor, although coyotes may consume a majority of the available carcasses.

Hunting is the primary cause of adult mortality as described below. Parasites, diseases, and injuries take very few lives; however, during years with an acorn crop failure and a high population density, these factors might become important. Parasites may predispose lactating sows to starvation during the dry season. The main cause of "old age" deaths appears related to a slow process of tooth deterioration eventually leading to septicemia.

\section{HUNTING}

Hunting has undoubtedly been a major cause of mortality among the feral hogs since their introduction into the study area. It has been a principal fac- tor controlling hog distribution in eastern Tehama County. Prior to 1966, when the Dye Creek Preserve was started, no harvest records were kept. 
TABLE 14

ESTIMATED FERAL HOG MORTALITY CAUSED BY HUMANS ON THE DYE CREEK RANCH (SEPTEMBER OF ONE YEAR TO SEPTEMBER OF THE NEXT)

\begin{tabular}{|c|c|c|c|c|}
\hline Category of kill & $1966-1967$ & $1967-1968$ & 1968-1969 & 1969-1970* \\
\hline $\begin{array}{l}\text { Recorded kill (including } \\
\text { wounding losses) }\end{array}$ & 36 & 92 & 108 & 87 \\
\hline $\begin{array}{l}\text { Unrecorded Ranch kill } \\
\text { (estimated) }\end{array}$ & 6 & 10 & 5 & 3 \\
\hline Total Ranch kill & 42 & 102 & 113 & 90 \\
\hline Poaching kill (estimated) & 25 & 40 & 30 & 25 \\
\hline Valley neighbor kill (estimated) & 15 & 110 & 46 & 5 \\
\hline Total non-Ranch kill & 40 & 150 & 76 & 30 \\
\hline Total annual kill & 82 & 252 & 189 & 120 \\
\hline
\end{tabular}

* Data available only to 1 June 1970 .

Thereafter, records were kept on sex, age, color, and tusk size of each kill. The following discussion is based on the recorded kills from September, 1966 to June, 1970, and on estimates of unrecorded losses caused by humans. The commercial hunting season set by the Preserve extends from November through May. The heaviest monthly harvest usually occurs in March, although kills are fairly well spaced throughout the season. Losses to neighboring landowners occur during the summer and early autumn.

\section{Annual kill}

The estimated total kill by humans averaged 160 per year, or about 20 percent of the average fall population (Table 14). The recorded kill averaged 79 hogs per year or about 50 percent of the estimated total kill. Although a few unrecorded kills were made by Ranch and Preserve employees, this number was decreasing. The major unrecorded loss of hogs was to poachers from the public land north of the study area, and to valley neighbors owning irrigated pastures. Feral hogs entered these pastures during the summer and caused a certain amount of damage. Usually, the neighbors trapped the hogs and either sold them or slaughtered them for their own use. In October, 1967, one neighbor captured and sold about 100 hogs which had been rooting up his pasture. This loss represented approximately 75 percent of the hogs in the Long Gulch subunit.

\section{Wounding losses}

Under the controlled conditions existing on a guided hunt, relatively few animals were not recovered when shot. A record of wounded animals was kept during the 1968 to 1969 and 1969 to 1970 hunting seasons. Known wounding losses were 5.9 and 2.5 percent of the recorded kill for these seasons, respectively, and decreased with increased experience of the guides and hunters. Normally, hunters did not shoot until they were fairly sure of a successful shot. This practice increased the chances of selecting the best target, and reduced wounding losses.

\section{Sex and age structure of the kill}

In the first season of commercial hunting little conscious selection was made for a specific sex or age group, although hunters preferred adults or yearlings to young hogs (Table 15). In the second season, considerable effort was made to select trophies. This resulted in a relatively low female kill and a high adult boar and barrow kill. It was then realized that to produce a maximum sustained harvest of trophies, both sexes should be harvested approximately equally. Thus, in the 1968 to 1969 and 1969 to 1970 harvests, the sex 
TABLE 15

SEX AND AGE STRUCTURE OF RECORDED FERAL HOG KILLS FOR FOUR HUNTING SEASONS ON THE DYE CREEK RANCH (1966 TO 1970)

\begin{tabular}{|c|c|c|c|c|c|c|c|c|c|c|}
\hline & \multicolumn{2}{|c|}{$1966-1967$} & \multicolumn{2}{|c|}{$1967-1968$} & \multicolumn{2}{|c|}{ 1968-1969 } & \multicolumn{2}{|c|}{$1969-1970$} & \multicolumn{2}{|c|}{ Average } \\
\hline & \multicolumn{4}{|c|}{ Sex } & No. & $\%$ & No. & $\%$ & No. & $\%$ \\
\hline Barrows & 6 & 17 & 22 & 24 & 19 & 18 & 7 & 8 & 54 & 20 \\
\hline Boars & 17 & 47 & 44 & 48 & 38 & 35 & 29 & 33 & 128 & 38 \\
\hline Sows & 13 & 36 & 26 & 28 & 51 & 47 & 51 & 59 & 141 & 42 \\
\hline \multicolumn{11}{|l|}{ Age } \\
\hline $\begin{array}{l}\text { Adults } \\
(25+\text { months })\end{array}$ & 10 & 33 & 53 & 58 & 68 & 63 & 40 & 46 & 177 & 53 \\
\hline $\begin{array}{l}\text { Yearlings } \\
\text { (13-24 months) }\end{array}$ & 12 & 40 & 20 & 22 & 30 & 28 & 36 & 41 & 98 & 30 \\
\hline $\begin{array}{l}\text { Young } \\
\text { (1-12 months) }\end{array}$ & 8 & 27 & 19 & 20 & 10 & 9 & 11 & 13 & 48 & 17 \\
\hline
\end{tabular}

TABLE 16

MEAN TUSK LENGTH (GUM TO TIP) AND PERCENTAGE OF TROPHIES (TUSKS 5 + CM) FOR FERAL BOARS KILLED ON THE DYE CREEK RANCH (1966 TO 1970)

\begin{tabular}{|c|c|c|c|c|c|}
\hline Item & 1966-1967 & $1967-1968$ & $1968-1969$ & $1969-1970$ & Average \\
\hline $\begin{array}{l}\text { Number of } \\
\text { samples } \\
\text { Mean tusk }\end{array}$ & 20 & 65 & 52 & 36 & 173 \\
\hline $\begin{array}{l}\text { length }(\mathrm{mm}) \\
\text { Percent } \\
\text { trophies }\end{array}$ & 33 & 45 & 45 & 41 & 43 \\
\hline
\end{tabular}

ratio was more balanced. As they gained experience, the guides became more selective in trying to find the class of hog desired by a hunter, while still manipulating the kill for an optimum sustained harvest.

\section{Tusk length and trophies}

The longest tusk was measured on each of the boars killed. The measurement was made to the nearest $5 \mathrm{~mm}$ from the gum line, around the greater curve, to the tip of the lower tusk. Any animal with a tusk $50 \mathrm{~mm}$ or longer was considered a trophy. Mean tusk length averaged $43 \mathrm{~mm}$ and the percentage of trophies in the total number of boars and barrows harvested averaged 37 percent (Table 16). Nearly all of the largest trophies were barrows, and barrows represented 48 percent of all trophy animals taken.

\section{Color composition of the kill}

Most hunters preferred a head that was black for a mounted trophy. During the first two hunting seasons the percentage of black hogs in the kill was greater than that in the population. There was concern that this situation might lead to a decrease in the number of black hogs available. Beginning with the 1968 to 1969 season, guides made a special effort to select for nonblack hogs. The percentage of black hogs killed dropped from 66.7 in 1966 to 1967 to 41.4 percent in 1969 to 1970 . In the 1969 to 1970 season at least seven ( $8 \%$ ) of the recorded kills had agouti patterns which indicated they were hybrids resulting from the European wild boar breeding program.

\section{Discussion}

Two important points emerge from the data on hunting mortality: (1) regulation of hunting pressure can be used successfully to manipulate the Dye Creek feral hog population, and is likely to be the most economical man- 
agement tool available, and (2) the data on the sex, age, and color composition of the kill indicate that it is pos- sible to influence hunter selectivity, a necessity for intensive population management.

\section{POPULATION CHARACTERISTICS}

By 1910, feral hogs were common in the foothills north and south of Mill creek. Most of the homesteaders moved from the roadless back country during the 1920 's, thereby greatly reducing human predation in that area. Local citizens kept the hog population along the valley edge at a low level until William Keeler purchased the Dye Creek Ranch in 1963 and restricted hunting. The valley edge population then began to increase, and, in the summer of 1964, hogs invaded the irrigated pastures of neighboring landowners (Messrs. G. Vodjansky and C. C. Glidden, pers. comm., 1969).

While numbers of hogs along the valley edge were increasing, those in the foothills were declining. From 1964 to 1966, the Pacific Gas and Electric Company constructed a power line and access road through the foothills, stimulating a rapid increase in hunting pressure on state-owned lands and making ranch lands easily accessible to poachers. Since the Dye Creek Preserve was organized in 1966, hunting has been regulated and distributed more evenly over the ranch, and the hog population has increased an average of 10 percent per year (up to 1970).

\section{Density}

Throughout the study, estimates of population size were determined by two methods. The most reliable technique involved calculating the ratio of tagged and recognizable animals to unrecognizable individuals. Aerial reconnaissance of hog sign throughout the study area was used to make population estimates for the entire area by extrapolating densities derived from local estimates.
In 1967, about 75 percent of the hogs in the Long Gulch unit were trapped and tagged or recognized as individuals by a distinctive coat-color pattern. Observations throughout that summer of the proportion of recognizable animals to unrecognizable ones indicated that there were about $140 \mathrm{hogs}_{\mathrm{s}}$ in this unit in September. All annual estimates were made in September, when the population was at its lowest seasonal density.

In September, a light plane was used to carefully survey the entire study area for hog sign. Rooting, trails, and bedgrounds were visible at this time of year due to the trampled dry grass. No other large animals remained in the area during the summer, and all sign could be attributed to the hogs. An estimate of 750 hogs was made for the total Dye Creek population based on the figure of 140 individuals in the Long Gulch unit, and the relative amount of hog sign in this unit and the rest of the study area. This method seemed reasonably reliable in this case, but its value would decrease with increasing tree and shrub cover.

In 1968, more hogs were tagged and more were individually recognizable in all parts of the study area. In the fall of 1967, most of the Long Gulch population was trapped and removed by a neighboring rancher. For this reason the Kingsley unit was chosen for intensive study. Its population was estimated to include 175 animals in September, 1968. An aerial survey of hog sign was again made, and the total Dye Creek population was estimated to be 800 hogs.

In 1969, I recognized a sufficient number of individuals throughout the 
TABLE 17

ESTIMATED POPULATION AND CARRYING CAPACITY FOR FERAL HOGS ON THE DYE CREEK RANCH

\begin{tabular}{|c|c|c|c|c|c|}
\hline \multirow{2}{*}{ Management unit } & \multirow{2}{*}{1967} & \multirow{2}{*}{1968} & \multirow{2}{*}{1969} & \multicolumn{2}{|c|}{ Estimated carrying capacity } \\
\hline & & & & Number & Density $/ \mathrm{km}^{2}$ \\
\hline Long Gulch & & & & 70 & 5 \\
\hline Estimated total no. & 140 & 30 & 25 & & \\
\hline No. actually sighted & 100 & 24 & 14 & & \\
\hline (\% of estimate) & 71 & 80 & 56 & & \\
\hline Kingsley & & & & 150 & 6 \\
\hline Estimated total no. & 150 & 175 & 205 & & \\
\hline No. actually sighted & 55 & 125 & 200 & & \\
\hline (\% of estimate) & 37 & 71 & 97 & & \\
\hline Allen & & & & 140 & 6 \\
\hline Estimated total no. & 120 & 120 & 125 & & \\
\hline No. actually sighted & 29 & 73 & 105 & & \\
\hline (\% of estimate) & 24 & 61 & 84 & & \\
\hline Ballard & & & & 190 & 8 \\
\hline Estimated total no. & 210 & 200 & 235 & & \\
\hline No. actually sighted & 79 & 125 & 232 & & \\
\hline (\% of estimate) & 38 & 62 & 99 & & \\
\hline Wildcat & & & & 200 & 5 \\
\hline Estimated total no. & 130 & 275 & 315 & & \\
\hline No. actually sighted & 65 & 192 & 303 & & \\
\hline (\% of estimate) & 50 & 70 & 96 & & \\
\hline Total ranch & & & & 750 & 6 \\
\hline Estimated total no. & 750 & 800 & 905 & & \\
\hline No. actually sighted & 329 & 539 & 854 & & \\
\hline (\% of estimate) & 44 & 67 & 94 & & \\
\hline
\end{tabular}

TABLE 18

WILD-PIG DENSITY ESTIMATES SELECTED FROM THE LITERATURE

\begin{tabular}{|c|c|c|c|}
\hline Location & Density (pigs $/ \mathrm{km}^{2}$ ) & Habitat & Authority \\
\hline Germany & 0.04 & Primeval forest* & Oloff 1951 \\
\hline India & 0.08 & Dry woodland* & Berwick and Jordan 1971 \\
\hline California & $0.5-0.8$ & Chaparral-woodland & Pine and Gerdes 1973 \\
\hline Poland & $1.2-1.8$ & Mixed forest & Mackin 1970 \\
\hline Russia & $1.2-1.9$ & Mixed forest & Kozlo 1970 \\
\hline Czechoslovakia & 3.1 & 'Forest preserve & Janda 1958 \\
\hline Southeastern U.S.A. & 3.9 & Mixed forest & Hanson and Karstad 1959 \\
\hline Germany & 5.6 & Forest preserve & Leopold 1936 \\
\hline Armenia & 6.9 & Forest & Safarov 1960 \\
\hline Germany & 7.7 & Marsh & Oloff 1951 \\
\hline Java & 7.7 & Monsoon forest* & Hoogerwerf 1970 \\
\hline New Zealand & 25.0 & Native forest & Thomson 1922 \\
\hline Hawaii & 48.0 & Fern forest & Nichols 1962 \\
\hline New Zealand & $35-115$ & Native forest & Wodzicki 1950 \\
\hline
\end{tabular}

study area to make a total population estimate based solely on ground observations. In September, 1969, I could recognize 94 percent of the hogs I saw. Therefore, since 854 individuals were known, an estimate of 905 hogs probably is close to the true population at that time. Although adults were being harvested by hunters through the win- ter, by the spring of 1970 , normal reproduction presumably raised the population to 1,000 .

A check was made on the earlier estimates by analyzing all the known-aged individuals tagged or killed on the ranch as of May, 1970 (Table 17). These results substantiate earlier estimates . 


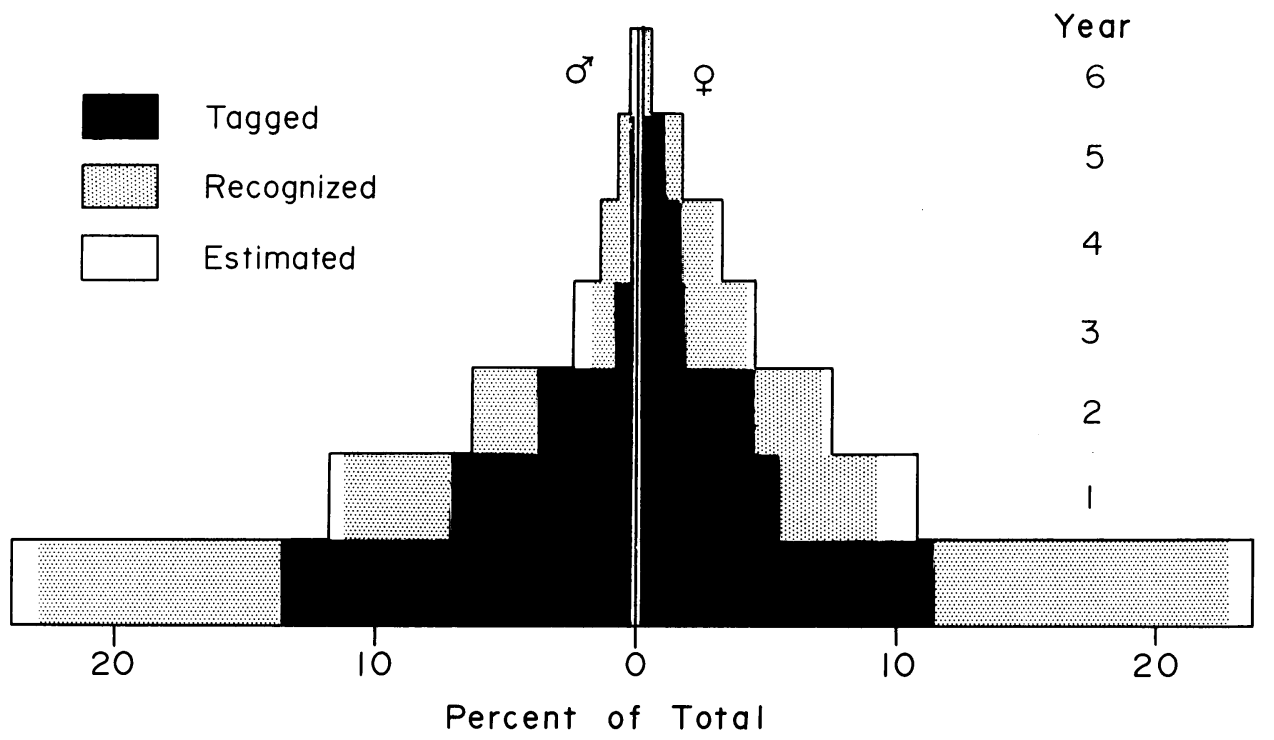

Fig. 25. Sex and age structure of the Dye Creek feral hog population in September, 1969. The young (bottom) age class represents only 6- to 12-month-old hogs. The male data include barrows. Of the total 905 estimated hogs, 53 percent were tagged and 94 percent were either tagged or individually recognizable.

The range of the Dye Creek hogs includes approximately $130 \mathrm{~km}^{2}$. Dividing the population estimates by this figure gives average densities varying from five to eight hogs $/ \mathrm{km}^{2}$ over the 5 years. Six hogs $/ \mathrm{km}^{2}$ is close to the density that a dry oak woodland of this type will support on a long-term basis. The figure would be lower for areas with greater amounts of non-mast-producing trees and shrubs but possibly higher for dense oak forests or marsh habitats. The data in Table 18 provide a number of wild pig density estimates for comparison.

\section{Population structure}

The Dye Creek feral hog reproduces in all months of the year but experiences a differential survival of the young by season. Population structure estimates in this case are more difficult to make than for a population that reproduces during a short period. I chose September as the best month for establishing the population structure because: (1) at that time the greatest pro- portion of young are over 6 months old, (2) the population is at its lowest point, and (3) September is just before the opening of the Preserve's boar-hunting season. Young less than 6 months old were disregarded for, although at times they make up a large part of the population, they have a very low survival rate. Young 6 to 12 months old are easier to census and give a better indication of the year's production.

The estimated structure of the Dye Creek hog population for September 1969 (Fig. 25) is based on: (1) trapped animals aged by tooth eruption and wear pattern, (2) recognized animals aged according to their size and dominance, and (3) estimated unidentified animals in the population. The last category was determined from proportions of identifiable to unidentifiable animals in field observations.

Young comprised 48.8 percent of the population, and yearlings formed 22.8 percent of the total. The sex ratio of young hogs was 1.0. Of the adult (13+ months) population, boars and barrows 
TABLE 19

DATA ON WILD PIG POPULATIONS FROM VARIOUS COMBINATIONS OF OBSERVATION, TRAPPING, AND SHOOTING AT VARIOUS SEASONSDERIVED FROM THE LITERATURE

\begin{tabular}{|c|c|c|c|c|}
\hline $\begin{array}{l}\text { Location } \\
\text { period }\end{array}$ & $\underset{\text { size }}{\text { Sample }}$ & $\begin{array}{l}\text { Adult boars/ } \\
100 \text { adult sows }\end{array}$ & $\begin{array}{l}\text { Young/100 } \\
\text { adult sows }\end{array}$ & Source \\
\hline $\begin{array}{l}\text { Russia } \\
\qquad 1960-1963\end{array}$ & 580 & 100 & 133 & Kozlo 1970 \\
\hline $\begin{array}{c}\text { Dye Creek } \\
1969\end{array}$ & 905 & 84 & 173 & This study \\
\hline $\begin{array}{l}\text { Russia } \\
\qquad 1936-1952\end{array}$ & 734 & 98 & 197 & Sludskii 1956 \\
\hline $\begin{array}{l}\text { Germany } \\
\quad 1840-1940\end{array}$ & unknown & 100 & 200 & Oloff 1951 \\
\hline $\begin{array}{l}\text { Poland } \\
\qquad 1946-1948\end{array}$ & 2,859 & 150 & 360 & $\begin{array}{l}\text { Severtzov and } \\
\text { Sablina } 1953\end{array}$ \\
\hline $\begin{array}{l}\text { S. Carolina } \\
1968-1969\end{array}$ & 160 & 105 & 519 & Sweeney 1970 \\
\hline $\begin{array}{l}\text { Germany } \\
\quad 1962-1970\end{array}$ & 172 & 107 & 568 & Ueckermann 1972 \\
\hline $\begin{array}{l}\text { Monterey } \\
\quad 1966-1967\end{array}$ & 124 & 166 & 1,110 & $\begin{array}{l}\text { Pine and Gerdes } \\
1973\end{array}$ \\
\hline
\end{tabular}

comprised 46.4 percent and sows 53.6 percent. The uneven adult sex ratio probably is due to the selection for boars by hunters in past years. Barrows made up at least 19 percent of all male hogs.

From 1967 to 1969, the ratio of young to 100 adult sows ranged from 24 to 289 in the various management units (Barrett, 1971). Production of young by the total population dropped slightly (119 to 104 young per 100 sows) from 1967 to 1968, but increased substantially (173 per 100 sows) in 1969 due to improved food conditions. The data for the Ballard unit show best the effect of a good acorn crop on production of young, because it is in the foothills where the hogs do not benefit from the irrigated pastures. From 1968 to 1969, the ratio of young to 100 sows increased from 72 to 212 . The Dye Creek population structure is compared with those of other wild pig populations in Table 19.

\section{Survival curves}

Two estimates of mortality in the Dye Creek hog population are presented in Fig. 26. The mortality rate from conception to parturition was calculated (Deevey, 1947; Caughley, 1966)

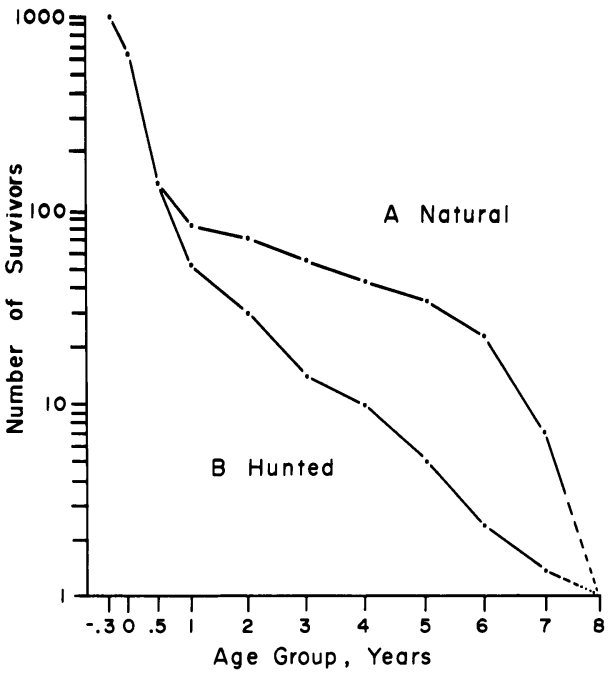

Fig. 26. Survival curves for (A) a "natural" feral hog population based on the age structure of 74 skulls collected from mortalities that were not human-caused, and (B) a "hunted" population based on the 1969 age structure and reproductive data for the Dye Creek hogs.

from: (1) the mean number of corpora lutea and live fetuses per sow, (2) the proportion of adult (13+ months) sows in the 1969 population, and (3) the assumption of a 99 percent fertility rate with two litters per year. The 1969 age structure was then used to develop the survivorship curve for a "hunted" pop- 
TABLE 20

EVISCERATED WEIGHTS OF FERAL HOGS AND ACORN CROP QUALITY ON THE DYE CREEK RANCH (1966 TO 1970)

\begin{tabular}{c|cccc}
\hline \hline \multirow{2}{*}{ Item } & \multicolumn{3}{c}{ Season } \\
\cline { 2 - 5 } & $1966-1967$ & $1967-1968$ & $1968-1969$ & $1969-1970$ \\
\hline $\begin{array}{c}\text { Quality of } \\
\text { acorn crop }\end{array}$ & Good & Poor & Good & Excellent \\
$\begin{array}{c}\text { Mean eviscerated } \\
\text { woight/pig (kg) }\end{array}$ & 56.5 & 50.8 & 56.5 & 61.3 \\
Sample size & 36 & 92 & 102 & 85 \\
\hline
\end{tabular}

ulation, and the age distribution of 74 skulls collected in the field from mortalities other than those caused by humans was used to develop the curve for a "natural" population. The calculated life expectancy from 6 months is 4.3 years for the natural curve, but only 1.6 years for the hunted curve.

The life expectancy figures for the hunted population, being based on the age structure of an increasing population, are slightly lower than might be expected for a stationary population. Even so, the curves in Fig. 26 clearly illustrate the heavy mortality of young, the effect of hunting on the adult population, and the rapid increase in natural mortality of old hogs due to tooth deterioration.

\section{Discussion}

The most important factors causing seasonal and annual population fluctuations of the Dye Creek hogs are (1) acorn production, (2) severity of the summer dry season, and (3) the intensity and selectivity of hunting. The density of hogs per square kilometer increased from five to eight over 5 years despite an average annual harvest of 20 percent. The feral hog's ability to reproduce is reflected in the population structure data for 1969 by an annual increment (young over 6 months) of almost 50 percent, a mean age of 22 months, and a mean life expectancy from birth of only 10 months.

A seasonal mast crop is the common factor stimulating wild pig growth and reproduction in both California and
Europe. Two consecutive years of above average acorn crops undoubtedly contributed to improved reproduction and survival of young in 1969 and 1970. The data on nutrition and growth show that acorns are the food item responsible for major seasonal weight gains, and that average hog weights vary annually with the size of the acorn crop (Table $20)$. These results are similar to those of Oloff (1951), Matschke (1964), and Kozlo (1970).

Throughout much of Europe, severe winter weather is an important cause of wild pig mortality (e.g. Sludskii, 1956; Cabon, 1958a). Conversely, at Dye Creek, the hot, dry summer with its attendant shortage of green forage is the critical season. My data on growth, reproduction, and mortality strongly suggest that, even in good acorn years, many sows, especially yearlings in the foothills, lose their litters because the quality of the available food is insufficient for normal milk production. Young that are weaned in the back country during the summer often stop growing and may even lose weight.

With no mortality, an even sex ratio, and production of 10 young per sow per year, the population doubling time is only 4.6 months. This relatively high reproductive potential added to their unsynchronized breeding habit enables feral hogs to withstand mortality rates well above those tolerated by other ungulates. Feral hogs can quickly respond to seasonal improvements in food supply and rapidly repopulate an area after severe population reduction. This 
situation poses both the opportunity for a large annual yield, and the necessity for a substantial harvest fre- quently enough to control the population and prevent environmental damage.

\section{MANAGEMENT}

The wild pig is the second most important big-game species in terms of total population and annual hunter kill in California (California Department of Fish and Game, 1968, "Feral Animals in California," 11 pp. mimeo.; 1968, "Annual Summary of Statewide Game Bag," mimeo. report). A feral hog is considered a game animal under the State Fish and Game Code, and therefore is under the jurisdiction of the Department of Fish and Game. However, if a landowner captures and puts his "mark" on a feral hog, he can claim it as his own livestock and sell it. This legal technicality could complicate statewide management of wild pigs. Because they are a big-game species, methods of hunting wild pigs are restricted by state law, but as of 1970 there was no closed season and no bag limit for the feral hogs in Tehama County.

In most areas of California where wild pigs occur, the major opportunities for management lie with private landowners. The following discussion will be directed towards management by private ranchers. I will assume that:

(1) the management policy chosen by the landowner will be directed toward producing maximum sustained income per acre of land, and (2) wild pigs already occur on the land.

I caution against the introduction of pigs of any type into areas lacking them. They can have significant and often detrimental effects on the environment (Barrett, 1971; Bratton, 1974, 1975), and they are difficult, if not impossible to exterminate from large areas of heavily vegetated country (Taber, 1965; Allison, 1967). The average private landowner would require the financial aid of state or federal agencies for an extermination program over a large area. Therefore, any proposed introduction should be discussed with the Department of Fish and Game and should not be taken lightly.

Assuming, then, that the landowner has some wild pigs and cannot afford to exterminate them, he is faced with two management questions: (1) What is the optimum number of wild pigs for his economic and ecological circumstances? and (2) What is the best method for controlling the population?

\section{Maximum allowable density}

The maximum allowable density of wild pigs will depend on (1) the type, extent, and distribution of habitats present, (2) the type of economic enterprises utilizing these habitats, (3) the cost of wild pig control, and (4) the income available from the pigs. Most landowners in the foothill region of California are ranchers of cattle or sheep, and much of their property is grassland or oak savanna. At present, most ranchers receive no income from wild pigs, and a pig population which competes with livestock for forage is undesirable. Oloff (1951) has suggested a maximum allowable density of one wild boar per square mile $\left(0.4 / \mathrm{km}^{2}\right)$ to minimize agricultural damage in Germany. Pine and Gerdes (1973) found that an estimated density of one to two pigs per square mile $\left(0.4-0.8 / \mathrm{km}^{2}\right)$ interfered little with the livestock industry in Monterey County. Such a density probably is a realistic maximum for most ranching property in the state.

On the other hand, a landowner whose property is fairly wooded and who is able to derive some income from wild pigs could allow a population of up to six pigs $/ \mathrm{km}^{2}$ without an inordinate loss of cattle or sheep forage. A 
very heavily wooded area supporting few livestock might safely carry a few more pigs.

\section{Methods of control}

The method of control used will depend mainly on costs and the intensity of management desired. Many landowners presently shoot all pigs on sight. This practice takes little time, and the cost is low if it can be done in conjunction with other work. But special effort may be necessary at times to control pigs in specific trouble spots. This method does not produce any benefit other than to prevent damage to other resources and occasionally to provide pork for home consumption.

Hunting with dogs is a reasonably successful method of control but is expensive in terms of time and labor. Labor costs could be lowered by allowing sportsmen on the property to reduce the hog population, but this could be costly in terms of hunter-caused damage and time needed to control the sportsmen. Also, unguided sportsmen may not be willing to expend enough effort to control the population. Trapping (Giles, 1973) can be used successfully in local areas, but again considerable time and labor are necessary. Poisoning (Mackintosh, 1950) and the introduction of disease (Taber, 1965) are possibilities, but they may result in losses of domestic animals and wildlife depending on the type of poison and bait or disease used.

If it is absolutely essential to keep wild pigs out of a small area, fencing (Tilley, 1973) may be the most economical alternative. If electricity is available and the need for the fence is seasonal, a one- or two-strand electric fence (Wright, 1972) may be practical. One strand of electric wire was added to $3.2 \mathrm{~km}$ of barbed-wire fence on the study area to keep feral hogs from entering certain irrigated pastures during the summer. The electric wire was placed 20 to $25 \mathrm{~cm}$ above the ground, and the vegetation along the fence was treated chemically in the spring to prevent short circuits along the wire.

The above methods do not consider the possibility of obtaining a direct income from wild pigs. In California, there are two possible methods of selling wild pigs. Some landowners regularly trap feral hogs and sell them at auction. In many situations, the price obtained at auction for a feral hog would not cover the cost of the labor and transportation. However, if the animals can be captured with little effort in the winter when fat, and an auction is nearby, this method might be economically sound.

Paid recreational hunting is now a reality for several species of game in Califorina and other states (Long, 1968; Schreiner, 1968; Severson and Gartner, 1972). A wild pig will command a higher price for its recreational value than for its meat value in most parts of California. Thus, in some areas it may be possible to control a wild pig population by paid recreational hunting.

The landowner can sell recreational hunting by means of at least three different systems (Barrett, 1970): (1) $\mathrm{He}$ can simply charge a fee and let hunters on his land. However, this system permits little regulation of the hunters, commands a low price per kill, and without advertising may not adequately control the population. (2) $\mathrm{He}$ can sell a hunting concession to a local guide who would handle all details or to a larger preserve operation which would simply add his land to their program. A contract could provide for the concessionaire to harvest a minimum number of hogs. (3) $\mathrm{He}$ can, if he has sufficient land and other game species, set up his own commercial hunting preserve. He might then hire a manager who would take care of all details concerning hunters and wildlife management. The Dye Creek Preserve is an example of the last system. 


\section{Dye Creek Preserve}

The management of feral hogs on the Dye Creek Ranch is outlined to exemplify the potential value of wild pigs to the private landowner. The situation at Dye Creek is an example of one rancher's efforts to develop the recreational and wildlife resources on his land.

The policy in this case is one of multiple use, to make the greatest longterm profit per acre of land by establishing as many enterprises on the land as is ecologically and economically feasible. The major profit from the land is produced by a beef-cattle enterprise. In addition, various types of public recreation, including hunting, are sold through the Dye Creek Preserve. Both the Ranch and Preserve enterprises use the same land but are managed by different personnel who are coordinated by the landowner.

The primary method of controlling feral hogs is through paid recreational hunting. As in any market situation, an attempt must be made to balance the constraints of the resource and the desires of the consumer. The manager must consider the needs of the hunter, including type of animal desired, conditions of the hunt, supplemental amenities desired, and finally, ability and willingness to pay for the product. These factors will vary among individual hunters, and there is always the possibility of modifying the hunter's desires through education or persuasion.

Most hunters want an adult, black boar with tusks large enough to look presentable when the head is mounted as a trophy. Tusks with a length of 5 or more centimeters from the gum can be pulled out of the jaw to look longer; shorter tusks are difficult to extend. Because of the greater demand for this class of animal, a greater price may be asked for it. Some hunters are more concerned with enjoying the hunt and obtaining meat. Young hogs and sows in good condition provide excellent meat, whereas that from adult boars is generally lean, tough, and gamy.

All boar hunts at Dye Creek are guided, and transportation is provided. This plan eliminates hunter caused damage to structures, range, or livestock, and it helps to insure that the hunter will be successful and have a satisfactory experience. Hunts are organized from November to May. At this time, the weather is best for hunting, and the hogs are in better condition and are more active during the day. An extensive network of roads (Fig. 2) enables an even distribution of hunting activities, and facilitates the retrieval of kills. However, hunting from a vehicle is relatively unsuccessful, and most hunting is done on foot. Dogs are not used at Dye Creek but may be essential in areas with extensive dense vegetation such as the North Coast Range of California.

To maximize economic returns, the manager must determine the most desirable hog population with respect to other land uses and other game species, and the optimum sex and age composition of the annual harvest. He must know the ability of the population to produce a given class of animals at a given population density and population structure.

At Dye Creek, the first goal of management is to keep the total population at or below the estimated carrying capacity of six hogs $/ \mathrm{km}^{2}$. Then the population structure can be shifted by selective harvest to produce the maximum number of animals of a desired class.

A proposed optimum population structure for the production of trophy boars similar to that proposed for Polish wild boar by Wlazelko (1969) is shown in Fig. 27. The proposed harvest is indicated by the shaded areas. The September, 1969, population structure is shown for comparison, with the average annual recorded kill for 1966 to 1969 indicated by shading. 

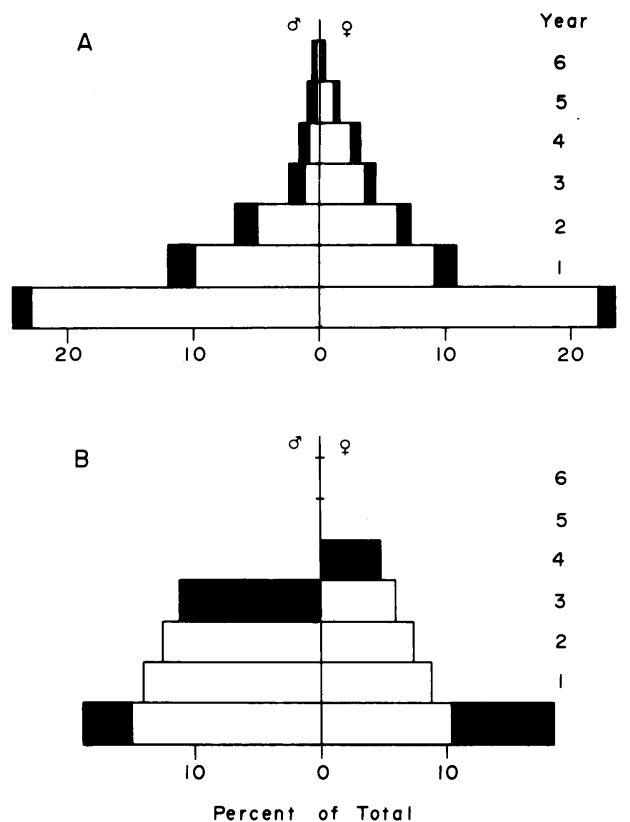

Fig. 27. Present (A) and proposed (B) feral hog population structures for the Dye Creek Ranch. Males include barrows. Shaded areas represent the annual (recorded) harvest.

Theoretically, by removing the given percentage of young, a greater number of adults can be carried to 3 or 4 years of age on the available forage. Oloff (1951) pointed out that trophy boar production in Germany is improved when young pigs comprise up to 80 percent of the annual harvest. Also, by harvesting a greater proportion of young sows than young boars, the adult sex ratio is shifted to 150 boars per 100 sows. Assuming the remaining sows produce an average of $1.9,6$ to 12-monthold young per sow per year and a 10 percent natural mortality of hogs over 6 months old, the proposed population structure can be maintained. These two characteristics will vary annually with variation in acorn production and the severity of summer drought. However, the figures given are the best estimates of average production and mortality available at present. All boars over 3 years old (11 percent of the population) are harvested as trophy animals. If this scheme were carried out to the letter, it would require a 27 percent annual kill to control the population.

In most cases such control of the sex and age structure of a wild population would be impossible. Moreover, annual environmental fluctuations will require a corresponding variation in the harvest rate. But, the above scheme can be used as a management goal in a commercial preserve operation where hunting guides are used.

\section{Discussion}

Wild pig populations in the absence of large predators (the large felids and canids) may quickly reach high densities and cause environmental damage by rooting (Barrett, 1971) unless they are controlled by man. Potential management schemes range from simply shooting all hogs on sight, to the establishment of a commercial hunting enterprise such as the Dye Creek Preserve. Under this system, the hog population can be maintained at a suitable density, and be managed to produce the maximum long-term income from paid recreational hunting. Feral hog populations may be manipulated via habitat modification (Barrett, 1971); however, manipulation of the annual harvest probably is the more feasible management technique for a preserve enterprise. This necessitates keeping accurate population and harvest statistics, from which quotas can be set for selective harvests. In this manner the production of desirable animals can be maximized within the limits of the allowable population density. Experience at Dye Creek has shown that qualified hunting guides are the key to a selective harvest. 


\section{SUMMARY}

An extensive study of the life history and ecology of the feral hog Sus scrofa was made from 1967 to 1970 at the Dye Creek Ranch, Tehama County, California. The hog population stems from domestic stock released by homesteaders as early as 1890. European wild boar from Monterey County, California were introduced in 1968. The feral hogs exhibit a "lard type" conformation, a chromosome complement of 38 , and a mode teat number of 12 . About 46 percent are black, but 11 coat color patterns were recognized including spotted and belted patterns. Boars developed tusks (lower canines) $5 \mathrm{~cm}$ in length from gum to tip by 3 years of age. Tusks of old boars grew up to $10 \mathrm{~cm}$ gum-tip length. Feral pigs have a matriarchal social structure, adult boars living alone except when joining family groups for breeding. Family groups averaged 8.4 hogs. There was no evidence of territoriality. The preferred activity pattern was crepuscular, but extreme temperatures stimulated diurnal and nocturnal patterns in the winter and summer, respectively. Duration of daily activity was influenced by the seasonal quality and availability of food. Home ranges of boars and sows were estimated to be about 50 and 15 $\mathrm{km}^{2}$, respectively. Hogs were transplanted up to $15 \mathrm{~km}$ to determine homing ability.

Food habits were determined from stomach samples, scats, and feeding observations. Acorns were the most important food item. Green grass and forbs, wild oats, berries, bulbs, roots, insects, and carrion were also eaten. High volatile fatty acid concentrations in the caecum and stomach indicated a high rate of microbial activity and utilization of cellulose. Hogs grazing irrigated pastures during the summer dry season consumed more green forage and crude protein than hogs without access to pastures. Pen-raised feral hogs were capable of growth equal to domestic swine, but typical free-ranging hogs exhibited growth rates of only half their potential. An analysis of covariance indicated significant differences in growth between hogs with and without access to irrigated pastures.

Sows bred continuously after 6 to 10 months old, averaging two litters per year and 5.6 young per litter. Sows with access to irrigated pastures, evidenced a significantly higher reproductive rate than those without. From birth to 6 months of age, piglets sustained a 70 to 90 percent mortality. Losses were due to accidents, predation, and starvation. Insufficient milk production by the sow appeared to be the major underlying factor causing piglet losses. A low level of protein in the sow's diet was probably the primary cause of inadequate milk production. Hunting was the major cause of adult mortality. Tooth abscesses and related infections were probably the most important natural cause of adult hog mortality. Population density increased from five to eight hogs $/ \mathrm{km}^{2}$ on the 130 $\mathrm{km}^{2}$ study area, an increase of 10 percent per year for 5 years, although the annual kill averaged 20 percent. Young hogs over 6 months old made up nearly half, and yearlings made up nearly a quarter of the fall population in 1969.

The management program of the Dye Creek Preserve is presented as a means of economically controlling feral hog populations on private lands by paid recreational hunting, thus providing income for the landowner and recreation for the public. Procedures are suggested for maximizing trophy boar production through intensive population manipulation. Qualified hunting guides are the key to success in such a scheme. 


\section{ACKNOWLEDGMENTS}

The cooperation and financial support of William S. Keeler, Wayne Long, and many other Dye Creek Preserve personnel is gratefully acknowledged. This study was completed while the author was a doctoral candidate at the Museum of Vertebrate Zoology, University of California, Berkeley. The following individuals of the University of California provided assistance during the project: A. Starker Leopold, Marshall White, Harold F. Heady, James L. Patton, Gene M. Christman, Nobu Asami, Wilhemina Stefansky, Louis A.
Jaechel, John L. Strother, William M. Longhurst, John Oh, and Robert Harris. Bruce Browning and other members of The California Department of Fish and Game provided advice on various aspects of the work. The research was supported by a National Science Foundation Graduate Fellowship, The Union Foundation Wildlife Fund and the Department of Zoology-in addition to the Dye Creek Preserve. Finally, I thank Kathy Barrett for her neverending assistance in all aspects of the study.

\section{LITERATURE CITED}

ACKERNECHT, E.

1950. Anatomical differences between the wild and domestic pig. Z. Tierzuecht. Zuechtungsbiol. $58(4): 465-72$.

ADLERBERG, G.

1930. Preliminary synopsis of Russian and Mongolian wild boars. Dokl. Akad. Nauk SSSR $1930(\mathrm{~A}): 91-96$.

ALLison, M. M.

1967. Annual report, California District. U.S. Bur. Sport Fish. Wildl. Div. Wildl. Serv. 24 pp. Anderson, C. A.

1933. The Tuscan formation of Northern California with a discussion concerning the origin of volcanic breccias. Univ. Calif. Dept. Geol. Sci. Bull. 23(7) :215-76.

ANDERson, L. L., and R. M. MELAMPy

1972. Factors affecting ovulation rate in the pig. In: Pig Production, (D. J. A. Cole, ed.) pp. 329-66. London: Butterworths. 470 pp.

ANONYMOUS

1949. The wild boar (Sus scrofa). J. Bengal Nat. Hist. Soc. 24(1) :21-29.

ANSELL, W. F. H.

1965. Standardization of field data on mammals. Zool. Africana 1(1):97-113.

ANTHONY, D. J., and E. F. LEWIS

1961. Diseases of the pig, 5th ed. Baltimore, Md.: Williams and Wilkins Co. 407 pp.

ASDELL, S. A.

1964. Patterns of mammalian reproduction, 2nd ed. Ithaca, N.Y.: Comstock Publishing Co. $640 \mathrm{pp}$.

BAILEY, E. H., ed.

1966. Geology of Northern California. Calif. Div. Mines Geol. Bull. 190. 508 pp.

BARRETT, R. H.

1970. Management of wild hogs on private lands. Trans. Calif.-Nev. Sec. Wildl. Soc. 17:71-78.

1971. Ecology of the feral hog in Tehama County, California. Unpubl. Ph.D. Thesis, Univer-

BELIC, J. sity of California, Berkeley. $368 \mathrm{pp}$.

1938. Die Abstammung des Balkanwildschweines. Z. Tierzuecht. Zuechtungsbiol. 42(2) :151214.

Berwick, S. H., and P. A. JoRdAN

1971. First report of the Yale-Bombay Natural History Society studies of wild ungulates at the Gir Forest, Gujarat, India. J. Bombay Nat. Hist. Soc. 68(2) :412-23.

BEUERLE, W.

1975. Freilanduntersuchungen zum Kampf-und Sexualverhalten des europaeischen Wildschweines (Sus scrofa L.) Z. Tierpsychol. 39(2):211-58. 
Biswell, H. H.

1956. Ecology of California grasslands. J. Range Manage. 9(1):19-24. , and J. H. GiLLmaN

1961. Brush management in relation to fire and other environmental factors on the Tehama Deer Winter Range. Calif. Fish Game $47(2): 357-89$. , and C. J. Graham

1956. Plant counts and seed production on California annual-type ranges. J. Range Manage. $9(3): 116-18$.

BLANFORD, W. T.

1888-1891. The fauna of British India: Mammalia. London: Taylor and Francis. $617 \mathrm{pp}$.

BLOCKER, J. C. voN

1937. The mammals of Monterey County, California. Unpubl. Ph.D. Thesis, University of

BoKonyi, S. California, Berkeley. 338 pp.

1970. Animal remains from Lepenski vir. Science 167 (3926) :17.02-04.

BOLKAY, ST. J.

1929. On the endemic occurrence of Sus scrofa reiseri Bolkay, in Bosnia-Herzegovina. Inter-

Boubier, M. natl. Congr. Zool., Budapest 10:1382-85.

1929. Les sangliers aux environs de Genève. Bull. Soc. Zool. Genève 4:68-73.

BOYE, H.

1956. Vergleichende Untersuchungen ueber die arterielle Gefassversorgung des Uterus von Wild- und Hausschweinen. Z. Tierzuecht. Zuechtungsbiol. 67 (3) :259-96.

Bratton, S. P.

1974. The effect of the European wild boar (Sus scrofa) on the high-elevation vernal flora in Great Smoky Mountains National Park. Bull. Torrey Bot. Club 101(4) :198-206.

1975. The effect of the European wild boar, Sus scrofa, on Gray Beach Forest in the Great Smoky Mountains. Ecology $56(6): 1356-66$.

Braude, R., ed.

1972. Index of current research on pigs No. 18. Agr. Research Council, Tech. Com. on Pig Research, U. K. 217 pp.

BRIEDERMANN, L.

1967. Die Nahrungskomponenten des Schwarzwildes (Sus scrofa scrofa L.) in der Mitteleuropaeischen Kulturlandschaft. Trans. Congr. Internatl. Union Game Biol. 7:207-13.

1970. Zum Koerper- und Organwachstum des Wildschweines in der Deutschen Demokratischen Republik. Arch. Forstweseu 19 (4) :401-20.

1973. Das Schwarzwild (Sus scrofa L.). In Buch der Hege, Band I: Haarwild, (H. Stubbs, BRODY, S. ed.) pp. 123-54. Veb Deutscher Landwirtschaftsverlag. Berlin. 477 pp.

1945. Bioenergetics and growth. N.Y.: Hafner Publ. Co. 1023 pp.

Bromlei, G. F.

1964. Ussuriiskii Kaban. Isdatel'stuo Nauka, Moskiva. 107 pp.

Brown, G. T.

1895. Dentition as indicative of the age of the animals of the farm, 4 th ed. London: J. Murray. $61 \mathrm{pp}$.

BRUCE, J.

1941. More about the habits of the wild boar. Calif. Conser. 6(5) :14, 21.

BURCHAM, L. T.

1957. California rangeland. Calif. Div. Forestry, Sacramento. $247 \mathrm{pp}$.

BURGER, J. F.

1952. Sex physiology of pigs. Onderstepoort J. Vet. Research 25 (Suppl. 2) :3-218.

BuRNETT, J. L.

1963. Fracture traces in the Tuscan formation, Northern California. Calif. Div. Mines Geol., Spec. Rept. 82:33-40.

CABON, K.

1958a. Das Massensterben von Wildschweinen im Naturstattspark von Bialowieza im Winter 1955-56. Acta Theriol. $2(4)$ : 71-82.

1958b. Untersuchungen ueber die Schaedelvariabilitat des Wildschweines, Sus scrofa L. aus Nordospolen. Acta Theriol. 2(6):107-40. 
1959. Problem der Altersbestimmung beim Wildschwein Sus scrofa nach der Methode von Dub. Acta Theriol. 3(8):113-20.

Candau, L. R.

1959. La montanera extremena. Montes $15(88): 357-83$.

Caughley, G.

1966. Mortality patterns in mammals. Ecology 47(6) :906-18.

Christisen, D. M., and L. J. Korschaen

1955. Acorn yields and wildlife usage in Missouri. Trans. N. Amer. Wildl. Conf. 20:337-57.

COBURN, F. D.

1922. Swine in America. New York: Orange Judd Publ. Co. 583 pp.

Cran well, P. D.

1968. Microbial fermentation in the alimentary tract of the pig. Nutr. Abstr. Rev. 38(3):72130.

Cunha, T. J.

1957. Swine feeding and nutrition, Vol. 1. New York: Interscience Publishers. 296 pp.

DANIEL, C., and F. S. WooD

1971. Fitting equations to data: computer analysis of multifactor data for scientists and

DAY, B. N. engineers. New York: John Wiley and Sons. $342 \mathrm{pp}$.

1962. The reproduction of swine. In: Reproduction in Farm Animals, (S. E. Hafez, ed.) pp. 255-65. Philadelphia: Lea and Febiger. $367 \mathrm{pp}$.

DeEveY, E. S.

1947. Life tables for natural populations of animals. Quart. Rev. Biol. 22(4) :283-314.

Dehaut, E. G.

1939. Sur les facies géographiques des suides. Paris, Bull. Mus. Nat. Hist. Natur. N.V. 11:521-25.

Drong, C. H.

1973. Studies of the Malayan wild pig in Perak and Johore. Malay Nat. J. 26(3/4):120-51.

Dudzinski, M. L., and R. MYктTowrcz

1961. Eye lens as an indicator of age in the wild rabbit in Australia. CSIRO Wild. Res. $6(2): 156-59$.

Duncan, D. L., and G. A. Lodge

1960. Diet in relation to reproduction and the viability of the young: part 3 , pigs. Commonw. Bur. Anim. Nutr., Tech. Comm. 21. 106 pp.

DUNNE, H. W., ed.

1970. Diseases of swine. 3rd ed. Ames, IA.: Iowa State University Press. 1144 pp.

DutT, R. H., E. C. Simpson, J. C. Christian, and C. E. Barnhart

1959. Identification of preputial glands as the site of production of sexual odor in the boar. (Abstr.). J. Anim. Sci. 18:1157.

EIBL, K., and K. WETTKE

1964. Artificial insemination of pigs using $\mathrm{CO}_{2}$-inactivated boar semen. Vet. Rec. 76:865-68.

Elford, C. R., and M. R. McDonough

1964. The climate of Tehama County. U.S. Weather Bur., Univ. Calif. Agr. Ext. Serv., (Mimeo). Red Bluff, CA. 40 pp.

Elsley, F. W. H.

1971. Nutrition and lactation in the sow. In: Lactation (I. R. Falconer, ed.) pp. 393-441. London: Butterworths. $467 \mathrm{pp}$.

ENSMINGER, M. E.

1961. Swine science, 3rd ed. Danville, IL.: Interstate Printers and Publishers. 692 pp.

Environmental Science Services Administration

1969. Local climatological data annual survey, Red Bluff. Washington: U.S. Dept. Commerce. $4 \mathrm{pp}$.

EPSTEIN, H.

1969. Domestic animals of China. Commonw. Agr. Bur., Tech. Comm. 18. 166 pp.

1971. The origin of the domestic animals of Africa, Vol. II. New York: Africana Publ. Corporation. $719 \mathrm{pp}$.

Forbes, R. M., and T. S. HAmilton

1952. The utilization of certain cellulosic materials by swine. J. Anim. Sci. 11(3):480-90.

FRADRICH, H.

1967. Das Verhalten der Schweine (Suidae, Tayassuidae) und Flusspferde (Hippopotamidae). Handb. Zool. 10 (26) :1-44. 
France, N. W.

1969. A record wild boar of 1905 vintage. N. Z. Wild Life 25:28-30.

Fraser, A. F.

1968. Reproductive behaviour in ungulates. London: Academic Press. 202 pp.

GILES, J .

1973. Controlling feral pigs. Agr. Gaz. N. S. W. 84(3) :130-32.

Gordon, A., and A. W. SAMPSON

1939. Composition of common California foothill plants as a factor in range management. Univ. Calif. Agr. Exp. Sta. Bull. 627.95 pp.

Grauvogl, A.

1958. Ueber das Verhalten der Hausschweinen unter besonderer Beruchsichtigung des Fortpflanzungsverhaltens. Vet Med. Diss. Univ. Berlin. $81 \mathrm{pp.}$

Gropp, A., D. GIERS, and U. TETTENBORN

1969. Das Chromosomenkomplement des Wildschweins (Sus scrofa). Experientia, Basel 25: 778.

GUILBERT, H. R., and G. H. HART

1951. California beef production. Calif. Agr. Exp. Sta. Manual 2. Section 3, page 19.

GUNDLACH, H.

1968. Brutfuersorge, Brutpflege Verhaltensontogenese und Tagesperiodik beim Europaeischen Wildschwein (Sus scrofa L.). Z. Tierpsychol. 25(8) :955-95.

HABER, A.

1966. Pozywienie dzika. Lowiec Polski 14:2-3.

1969. Dzik. Warsaw: Panstw. Wyd. Roln, i Lesn. 215 pp.

HABERMEHL, K. H.

1961. Die Altersbestimmung bei Haustieren, Pelztieren und beim jagdbaren Wild. Berlin: Paul Parey. 212 pp.

HAFez, E. S. E., and I. A. Dyer

1969. Animal growth and nutrition. Philadelphia: Lea and Febiger. $402 \mathrm{pp}$. , and J. P. Signoret

1969. The behaviour of swine. In: The Behaviour of Domestic Animals, 2nd ed. (E. S. E. Hafez, ed.) pp. 349-90. Baltimore, MD.: Williams and Wilkins Co. 619 pp.

HALTENORTH, T.

1963. Klassifikation der Saugetiere. Artiodactyla. Handb. Zool. 8(32), 1(18):1-167.

Hanson, R. P., and L. KARSTAD

1959. Feral swine in the southeastern United States. J. Wildl. Manage. 23(1):64-74.

HARTHOORN, A. M.

1965. Application of pharmacological and physiological principles in restraint of wild animals. Wildl. Monogr. No. 14:1-77.

HEADY, H. F.

1956. Changes in a California annual plant community induced by manipulation of natural mulch. Ecology 37 (4) :798-812.

1958. Vegetational changes in the California annual type. Ecology 39(3):402-16.

1977. Valley grassland. In Terrestrial vegetation of California. (M. G. Barbour and J. Major, eds.) pp. 491-415. N.Y.: John Wiley \& Sons. 1002 pp.

Heitman, H.

1954. California swine production. Calif. Agr. Exp. Sta. Manual 17. 56 pp.

HENRY, V. G.

1966. The European wild hog hunting season recommendations based on reproductive data. Proc. Ann. Conf. S. E. Assoc. Game Fish Comm. 20:139-45.

1968. Fetal development in European wild hogs. J. Wildl. Manage. 32(4) :966-70.

1969. Estimating whole weights from dressed weights for European wild hogs. J. Wildl. Manage. 33(1) :222-25.

1970. Weights and body measurements of European wild hogs in Tennessee. J. Tenn. Acad. Sci. 45(1) :20-23.

, and R. H. CoNLEY

1972. Fall foods of European wild hogs in the southern Appalachians. J. Wildl. Manage. $36(3): 854-60$. 
HenRy, V. G ., and G. H. MATSChKe

1968. Immobilizing trapped European wild hogs with Cap-Chur-Barb. J. Wildl. Manage.

HOFLIGER, H. $32(4): 970-72$.

1931. Beitrag zur Anatomie von Sus scrofa L. und zum Domestikationsproblem. 7. Haarkleid und Haut des Wildschweines. Z. Anat. Entwicklungsgesch. 96 (5-6) :551-623.

HOLDRIDGE, L. R.

1967. Life zone ecology, rev. ed. Tropical Sci. Center, San Jose, Costa Rica. 206 pp.

HOOGERWERF, A.

1970. Udjung Kulon, the land of the last Javan rhinocerous with local and general data on the most important faunal species and their preservation in Indonesia. Leiden: E. J. Brill. $512 \mathrm{pp}$.

HorszczaruK, F.

1971. Badania nad trawieniem u swin (Hungarian, English summary). Biul. Insty. Genetyki i Hodowli Zwierzat PAN 21:101-72.

Hsu, T. C., and R. A. MEAD

1969. Mechanisms of chromosomal changes in mammalian speciation. In: Comparative Mammalian Cytogenetics (K. Benirschke, ed.) pp. 8-17. Berlin: Springer-Verlag. 473 pp.

HUIDEKOPER, R. S.

1903. Age of the domestic animals. London: F. A. Davis. $217 \mathrm{pp}$.

HULOT, F.

1969. Les chromosomes des suiformes. Ann. Genet. Selec. Anim. 1(4) :315-36.

Hutchison, C. B., ed.

1946. California agriculture. University of California Press, Berkeley, CA. 444 pp.

JANDA, M.

1958. Die Nahrung des Schwarzwilds (Sus scrofa) im Mittelgebirgsgebiet von Stiavnica. Saeugetierk. Mitt. 6(2):67-74.

Jensen, H. A.

1947. A system for classifying vegetation in California. Calif. Fish Game 33(4):197-266.

JONES, $\mathrm{P}$.

1959. The European wild boar in North Carolina. Game Div., N. Car. Wildl. Res. Comm., Raleigh, N.C. 29 pp.

IUMP, E. B., and M. E. WEAver

1966. The miniature pig in dental research. In: Swine in Biomedical Research (L. K. Bustad and R. O. McClellan, eds.) pp. 543-57. Richland, Wash.: Battelle Memorial Inst. 834 pp.

KAPPELI, J.

1908. Beitraege zur Anatomie und Physiologie der Ovarien von wildlebenden und gezahmten Weiderkauern und Schweinen. Landwirt. Jahrb. Schweiz. 22:53-129.

KELM, H.

1938. Die postembryonale Schaedelentwicklung des Wild- und Berkshireschweins. Z. Anat. Entwicklungsgesch. 108(4):499-559.

1939. Zur Systematik der Wildschweine. Z. Tierzuecht. Zuechtungsbiol. 43(3) :362-69.

KENNETH, J. H., and G. R. RiTCHIE

1953. Gestation periods: a table and bibliography, 3rd ed. Commonw. Bur. Anim. Breed. Genet., Tech. Comm. 5. 39 pp.

Kiessling, W.

1925. Das Schwarzwild und sein Jagd. Berlin: J. Neumann. 361 pp.

KORSCHGEN, L. J.

1969. Procedures for food-habits analyses. In: Wildlife Management Techniques, 3rd ed. (R. H. Giles, ed.) pp. 233-50. Washington, D.C.: The Wildlife Society. 623 pp.

KoRNYEYEV, O. P., and Ts. YU. KRYChEvS'KA

1967. Osoblyvosti zhyvlennya dykoho kabana na Ukrayini (Russian). Visn. Kyyiv. Univ. Ser. Biol. 9:150-54.

KozLo, P. G.

1968. Ecological and morphological characteristics of Sus scrofa from the Belovezhskaya Puschcha (in Russian, English summary) Vestnik Zool. 6:53-58.

1970. Factors determining the population density of the wild boar in the Belovezhskaya Puschcha (in Russian, English summary). Zool. Zhur. 49(3):422-30.

KRIDER, J. L., and W. E. CARroL

1971. Swine production, 4th ed. New York: McGraw-Hill Book Co. 528 pp. 
KROEBER, T.

1967. Ishi in two worlds. University of California Press, Berkeley, CA. 255 pp.

KuRz, J., and R. L. MARCHINTON

1972. Radiotelemetry studies of feral hogs in South Cerolina. J. Wildl. Manage. 36(4):124048.

LAIRD, A. K.

1966. Postnatal growth of birds and mammals. Growth $30(3): 349-63$.

LANDOLT, W.

1968. Vergleich des raeumlichen Verhaltens von Schmelz- und Dentinkronen-Relief im Dauergebiss des Schweins. Gegenbaurs Morphol. Jahrb. $112(3)$ :304-68.

LEOPOLD, A.

1936. Deer and Dauerwald in Germany, 2. Ecology and policy. J. For. 34(5):460-66.

LESLIE, W. W.

1966. Ball's ferry and Leslie's flour mill. The Covered Wagon, Fresno Hist. Soc., Fresno, Calif. 1966:49-51.

LEwIS, J. C.

1966. Observations of pen-reared European hogs released for stocking. J. Wildl. Manage.

LING, H. $30(4): 832-35$.

1955. Metssea (sus scrofa) areaalipiiri muutused Noukogude Baltimaadel Viimastel sajanditel (Eastonian). Loodus. Selts. Aast. 48:176-200.

LONG, W.

1968. Wildlife recreation on private land-a look to the future. Trans. Calif.-Nev. Sec. Wildl. Soc. 15:88-92.

Lund, A. P., and W. M. SAndstrom

1943. The protein of various true seeds. J. Agr. Res. 66(9) :349-55.

McCance, R. A., E. H. R. Ford, and W. H. B. Brown

1961. Severe undernutrition in growing and adult animals, 7. Development of the skull, jaws, and teeth in pigs. Brit. J. Nutr. 15(2):213-24.

MCFee, A. F., M. W. BANNeR, and R. L. MURPhreE

1965. Chromosome analysis of peripheral leucocytes of the sheep. J. Anim. Sci. 24(3):551-54.

MCFEe, A. F., M. W. BANNER, and J. M. RARY

1966. Variation in chromosome number among European wild pigs. Cytogenetics 5(1-2) :7581.

McKNIGHT, T. L.

1964. Feral livestock in Anglo-America. Univ. Calif. Publ. Geog. 16:1-78.

MCMeEkAN, C. P., and J. HAMmond

1940. The relation of environmental conditions to breeding and selection for commercial types in pigs. Empire J. Exp. Agr. 8(29):6-10.

MACKIN, R.

1970. Dynamics of damage caused by wild boar to different agricultural crops. Acta Theriol. $15(27): 447-58$.

Mackintosh, G. R.

1950. Destruction of wild pigs by poisoned baits. N. Z. J. Agr. 80 (3) :258-61.

MADDEN, D. H. L.

1962. A method of obtaining a high fertility level with the artificial insemination of farm pigs. Int. Congr. Anim. Reprod. 4:851-54.

MAJOR, C. J. F.

1883. Studien zur Geschichte der Wildschweine (Genus Sus). Zool. Anz. 6(140):295-300.

MANNA, G. K., and M. TALUKDAR

1965. Somatic chromosome number in twenty species of mammals from India. Mammal. Chrom. News. 17:77-78.

MANVILle, R. H.

1964. History of the Corbin Preserve. Smithsonian Inst. Ann. Rept. 1963. pp. 427-46.

MARKov, G.

1954. Ueber die Systematik des Wildschweines in Bulgarien. Izv. Zool. Inst. B. A. N., Sofia. 3:221-36.

Matchie, $P$.

1918. Das Wildschwein von Naliboki in Weissurssland. Sitzungsber. Ges. Naturforsch. Freunde. 8:1-5.

MATSChKe, G. H.

1962. Trapping and handling European wild hogs. Proc. Ann. Conf. S. E. Game Fish Comm. $16: 21-24$. 
1963. An eye lens-nutrition study of penned European wild hogs. Proc. Ann. Conf. S. E. Assoc. Game Fish Comm. 17:20-27.

1964. The influence of oak mast on European wild hog reproduction. Proc. Ann. Conf. S. E. Assoc. Game Fish Comm. 18:35-39.

1967. Aging European wild hogs by dentition. J. Wildl. Manage. 31(1):109-13.

MATSChKe, G. H., and J. P. HARDister

1967. Movements of transplanted European wild boar in North Carolina and Tennessee. P.R Proj. W-34-R-5, Tenn. Game Fish Comm., Nashville, TN. 17 pp. (Mimeo.).

MAUGET, $R$.

1972. Observations sur la réproduction du sanglier (Sus scrofa L.) a l'état sauvage. Annls. Biol. Anim. Biochim. Biophys. $12(2)$ : 195-202.

MedWAx, L.

1963. Pig's nests. Malay Nature J. $17(1): 41-45$.

MERriam, C. H.

1898. Life zones and crop zones of the United States. U.S. Dept. Agr., Bull. 10. 79 pp.

Miller, G. S.

1912. Catalogue of the mammals of western Europe (Europe exclusive of Russia) in the col lection of the British Museum. London: British Museum. 1019 pp.

Miller, G. S., JR., and R. KellogG

1955. List of North American recent mammals. U.S. Natl. Mus. Bull. 205. 945 pp.

MORRISON, F. B.

1956. Feeds and feeding. 22nd ed. Ithaca, N.Y.: Morrison Publ. Co. 1165 pp.

MORRISON, R.

1928. The individuality of the pig. New York: E. P. Dutton Co. 524 pp.

Mount, L. E.

1968. The climatic physiology of the pig. Baltimore, MD.: Williams and Wilkins Co. $274 \mathrm{pp}$.

MounT, L. E., and D. L. INGRAM

1971. The pig as a laboratory animal. New York: Academic Press. 175 pp.

Moustgaard, J.

1969. Nutritive influences on reproduction. Pp. 489-516. In : Reproduction in domestic animals (H. H. Cole and P. T. Cupps, eds.). New York: Academic Press. 657 pp.

MUnz, P. A., and D. D. KECK

1959. A California flora. University of California Press, Berkeley, CA. 1681 pp.

Muramoto, J., S. Makino, T. Ishikawa, and H. Kanagawa

1965. On the chromosomes of the wild boar and the boar-pig hybrids. Proc. Jap. Acad. $41(3): 236-39$.

Myers, K., and N. Gilbert

1968. Determination of age of wild rabbits in Australia. J. Wildl. Manage. 32(4) :841-49.

NACHTSheim, H.

1924. Untersuchungen ueber Variation und Vererbung des Gesauges beim Schwein. Z. Tierzuecht. Zuechtungsbiol. 2(2):113-61.

Nathusius, H. voN

1864. Vorstudien fuer Geschichte und Zucht der Hausthiere zunaechst am Schweineschaedel. Berlin: Weigandt und Hempel. 186 pp.

National Research Council

1964. Joint United States-Canadian tables of feed composition. Natl. Acad. Sci., Washington, D.C. Publ. 1232. 167 pp.

1968. Nutrient requirements of swine, 6th ed. Natl. Acad. Sci., Washington, D.C. Publ. 1599. 69 pp.

1969. United States-Canadian tables of feed composition, 2nd revision. Natl. Acad. Sci. Washington, D.C. Publ. 1684. 92 pp.

Nehring, A.

1888. Ueber die Form der unteren Eckzahne bei den Wildschweinen, sowie ueber das sogenannte Torfschwein (Sus palustris Rutimeyer). Sitzungsber. Ges. Naturforsch. Freunde. 2:9-16.

NICHOLS, L.

1962. Ecology of the wild pig. P-R Proj. W-5-R-13 Hawaii Div. Fish and Game, Honolulu. (Mimeo.). $20 \mathrm{pp}$. 
OLOFF, H. B.

1951. Zur Biologie und Oekologie des Wildschweines. Beitr. Tierk. Tierzuecht. 2(1) :1-95.

Parsons, J. J.

1962. The acorn-hog economy of the oak woodlands of Southwestern Spain. Geog. Rev. 52(2): 211-35.

Peirson, H. M., and I. H. Owtram

1945. The origin of pig breeds. N. Z. J. Agr. 71:391-94.

Pine, D. S., and G. L. Gerdes

1973. Wild pigs in Monterey County, California. Calif. Fish Game 59(2):126-37.

Pira, A.

1909. Studien zur Geschichte der Schweinerassen insbesondere der Jenigen Schwedens. Zool. Jahrb. Abt. Syst. Oekol. Geogr. Tiere Suppl. 10 (2) :233-426.

Plum, M.

1938. Inheritance of mammae in swine, a character involving partly symmetrical organs, Hereditas 24:216-30.

Protsch, R., and R. Berger

1973. Earliest radiocarbon dates for domesticated animals. Science 179(4070):235-39.

Pullar, E. M.

1953. The wild (feral) pigs of Australia: their origin, distribution and economic importance. Mem. Natl. Mus. Victoria. 18:7-23.

Quinto, M. G.

1957. The breeding habits of Berkshire swine. Philippine Agr. 41:319-26.

Rakov, N. V.

1970. Causes of mortality of the wild boar and its interrelationship with predators in the Amur Territory (in Russian, English summary). Zool. Zhur. 49(8):1220-28.

Rary, J. M., V. G. Henry, G. H. Matschke, and R. L. MUrPhree

1968. The cytogenetics of swine in the Tellico Wildlife Management Area, Tennessee. J. Hered. 59 (3) :201-04.

REID, V. H., and P. D. Goodrum

1957. Factors influencing the yield and wildlife use of acorns. Proc. Ann. La. St. Univ. For. Symp. 6:46-63.

Rerat, A.

1972. Protein nutrition and metabolism in the growing pig. Nutr. Abstr. Rev. 42(1) :13-39.

RINEY, T.

1955. Evaluating condition of free-ranging red deer (Cervus elaphus), with special reference to New Zealand. N. Z. J. Sci. Tech. Section B, 36(5) :429-63.

RIPKE, E.

1964. Beitrag zur Kenntnis des Schweinegebisses. Anat. Anz. 114 (2) :181-211.

Rogers, D. A.

1962. Surface geology of the east side of the Sacramento Valley, California. Calif. Div. Mines and Geol. Bull. 181. 67 pp.

Rolleston, G.

1877. On the domestic pig of praehistoric times in Britain and on the mutual relations of this variety of pig and sus scrofa ferus, Sus cristatus, Sus andamanensis and Sus barbatus. Trans. Linn. Soc. $1(2): 251-86$.

RUdDLE, F. H.

1964. Quantitation and automation of chromosome data with special reference to the chromosomes of the Hampshire pig (Sus scrofa) In: Cytogenetics of Cells in Culture (R. J. C. Harris, ed.) pp. 273-305. New York: Academic Press.

Ruperez-Cuellar, A.

1957. La encina y sus tratamientos. Madrid: Ediciones Selvicolas. $154 \mathrm{pp}$.

SADLEIR, R. M. F.S.

1969. The ecology of reproduction in wild and domestic mammals. London: Meuthen and Co. $321 \mathrm{pp}$.

SAFAROV, M. A.

1960. Census method for wild boar in Azerbaidjan (in Armenian, Russian summary). Izv. Akad. Nauk Azerb. S. S. R. Ser. Biol. No. 1:125-28.

SAYLER, A.

1969. Communal nursing in mice: influence of multiple mothers on the growth of the young. Science 164 (3885):1309-1910. 
SCHREINER, C.

1968. Use of exotic animals in a commercial hunting program. In: Introduction of Exotic Animals: Ecological and Socioeconomic Considerations (J. G. Teer, ed.) pp. 13-16. Symp. Caesar Kleberg Research Program Wildl. Ecol., Texas A. \& M. Univ., College Station, Tex. 25 pp.

SCHROTER, H.

1922. Das Verhalten der europaeischen zu den asiatischen Wildschweinen auf Grund der postembryonalen Schaedelentwicklung der europaeischen Wildschweine. Zool. Jahrb. Abt.

SEARLe, A. G. Syst. Oekol. Geogr. Tiere 46 (4) :303-56.

1968. Comparative genetics of coat color in mammals. London: Academic Press. 308 pp.

Severson, K. E., and F. R. Gartner

1972. Problems in commercial hunting systems: South Dakota and Texas compared. J. Range Manage. 25(2) :342-45.

Severtzov, S. A., and T. B. Sablina

1953. Olen, Kosulja i Kaban v zaproviednikie Bieloviezska Pusca. Trudy Inst. Morfol. Zhivotn. Akad. Nauk Sieviercowa 9:140-205.

Shaw, A. C.

1940. The European wild hog in America. Trans. N. Amer. Wildl. Conf. 5:436-41.

SHAw, E. B.

1940. Geography of mast feeding. Econ. Geog. 16(3) :233-49.

Signoret, J. P., and F. Du Mesnil du Buisson

1962. Etude du comportement de la truie en oestrus. Internatl. Congr. Anim. Reprod. 4:17175.

SILLAR, F. C., and R. M. MEYLER

1961. The symbolic pig: An anthology of pigs in literature and art. London: Oliver and Boyd. $193 \mathrm{pp}$.

Simpson, G. G.

1945. The principles of classification and a classification of mammals. Bull. Amer. Mus. Nat. Hist., Vol. 85. 350 pp.

Simpson, G. G., A. RoE, and R. C. Lewontin

1960. Quantitative zoology. New York: Harcort Brace and World. 440 pp.

Sisson, S., and J. D. Grossman

1938. The anatomy of the domestic animals. Philadelphia: W. B. Saunders Co. 972 pp.

SLUDSKII, A. A.

1956. Kaban, morfologiya, ekologiya, khozyaistvennoe i epizootologicheskoe zhachenie, promysel. Alma-Ama: Akademii Nauk Kazachskoi SSR. 220 pp.

SMITH, A. D. B., O. J. Robison, and D. M. BRYANT

1938. The genetics of the pig. Bibliogr. Genet. 12:1-160.

SMITH, W. W.

1952. Pork production. New York: MacMillan Co. 616 pp.

SNeTHLAGe, $\mathrm{K}$.

1967. Das Schwartzwild. Berlin: Verlag Paul Parey. 200 pp.

SOCIETY OF AMERICAN Foresters

1954. Forest cover types of North America. Washington, D.C. 67 pp.

SognNaEs, R. F., ed.

1963. Mechanisms of hard tissue destruction. Amer. Assoc. Adv. Sci., Washington, D.C. Publ. 75. $776 \mathrm{pp}$.

Sowls, L. K., and R. J. Phelps

1968. Observations on the African bushpig (Potamochoerus porcus L.) in Rhodesia. Zoologica $53(3): 75-84$

STEgeman, L. C.

1938. The European wild boar in the Cherokee National Forest, Tennessee. J. Mammal. 19(3) :279-90.

STEINBACHER, G.

1954. Zur Biologie des europaeischen Wildschweines (Sus scrofa Linne 1758). Saeugetierk. Mitt. 2:126.

Stemmer, G.

1909. Anatomisch-histologische Untersuchungen über den Schild der maennlichen Suiden mit Berücksichtigung der Fleischbeschau. Inaug. Diss., Univ. Bern. 50 pp.

Storer, T. I., and L. P. Tevis, Jr.

1955. California grizzly. Berkeley: Univ. California Press. 335 pp. 
SWEENEY, J. M.

1970. Preliminary investigations of a feral hog (Sus scrofa) population on the Savannah River Plant., South Carolina. Unpubl. M.S. Thesis, University of Georgia. 58 pp.

Sweeney, J. M., E. E. Provost, and J. R. Sweeny

1971. A comparison of eye lens weight and tooth eruption pattern in age determination of

TABER, R. D. feral hogs (Sus scrofa). Proc. Ann. Conf. S. E. Assoc. Game Fish Comm. 24:285-91.

1965. The emergent boars. Pac. Discovery $18(1): 10$.

TAlbot, M. W., H. H. Biswell, and A. L. HoRmay

1939. Fluctuations in the annual vegetation of California. Ecology 20 (3) :394-402.

Thenios, E.

1970. Zur Evolution und Verbreitungsgeschichte der Suidae (Artiodactyla, Mammalia). Z. Saeugetierk. 35(6) :321-42.

Thompson, D'ARcy W.

1942. On growth and form. London: Cambridge University Press. 1116 pp.

Thomson, G. M.

1922. The naturalisation of animals and plants in New Zealand. Cambridge: Cambridge University Press. $607 \mathrm{pp}$.

ThornthwaIte, C. W.

1948. An approach to a rational classification of climate. Geog. Rev. 38(1):55-94.

Tilley, L. G. W.

1973. Pig fencing in Mossman. Cane Growers Quart. Bull. 38(4) :132-33.

TorRent, J. A., G. VARELA, and J. BozA

1962. Digestibilidad y valor nutritivo de la bellota en cerdos y estudio de la capacidad de asentiamento en encinares. Montes 18(104):93-100.

Towne, C. W., and E. N. Wentworth

1950. Pigs from cave to cornbelt. Norman, OK: University of Oklahoma Press. 305 pp.

U. S. Department of Agriculture

1967. Soil survey of Tehama County, California. Soil Conserv. Serv. and Forest Serv., Washington, D.C. $124 \mathrm{pp}$.

UECKERMANN, E.

1972. Zur jaegdlichen Nutzungsfaehigkeit von Rot-, Dam-, und Schwarzwildbestanden nach Beobachtungen in einem Jagdgatter. Z. Jagdwiss. 18(1) :24-31.

Ullrey, D. E., J. I. Sprague, D. E. BeCKer, and E. R. Miller

1965. Growth of the swine fetus. J. Anim. Sci. 24 (3) :711-17.

VERESCHAGIN, N. K.

1967. The mammals of the Caucassus, a history and evolution of the fauna. Acad. Sci. U. S. S. R. Zool. Inst. (Trans, from Russian by Israel Program Sci. Transl., U. S. Dept. Commerce, Washington, D.C.) 816 pp.

VIRCHOW, $\mathrm{H}$.

1937. Ueber das Schweinegebiss mit Ausblicken auf die Gebisse anderer Saugetiere. Sitzungsber. Ges. Naturforsch. Freunde 51:12-54.

WARDROP, A. E.

1914. Modern pig-sticking. London: Macmillan \& Co. 304 pp.

WARWICK, B. L.

1928. Prenatal growth of swine. J. Morphol. Physiol. 46(1) :59-84.

WEAVER, M. E., and D. L. INGRAM

1969. Morphological changes in swine associated with environmental temperature. Ecology $50(4): 710-13$.

Weaver, M. E., E. B. Jump, and C. F. McKEan

1966. The eruption pattern of deciduous teeth in miniature swine. Anat. Record $154(1): 81-6$.

1969. The eruption of permanent teeth in miniature swine. Arch. Oral Biol. 14(3):323-31.

WESLEY, F., and F. D. KLOPFER

1962. Visual discrimination learning in swine. Z. Tierpsychol. 19(1):93-104

WHITE, K. L.

1966. Structure and composition of foothill woodland in Central Coastal California. Ecology $47(2): 229-37$

WLAZELKO, M.

1969. Hodowlany odstrzal Dzikow (Polish). Lowiec Polski 23-24:4-5, 9.

WoDzICKI, K. A.

1950. Introduced mammals in New Zealand, an ecological and economic survey. N. Z. Dept. Sci. Indust. Research, Wellington. Bull. 98. 255 pp. 
Wood, A. J., I. MCT. Cowan, and H. C. NordaN

1962. Periodicity of growth in ungulates as shown by deer of the genus Odocoilius. Can. J. Zool. $40(4): 595-603$.

Wood, G. W. (ed.)

1977. Research and management of wild hog populations, Procedures of a Symposium, April 13-14, 1977. Belle W. Baruch Forest Science Institute of Clemson University. Georgetown, S. Carolina. 113 pp.

Wood, G. W., J. B. HendRICKs, and D. E. Goodman

1976. Brucellosis in feral swine. J. Wildl. Diseases 12(5) :579-82.

WRATHALL, A. E .

1971. Prenatal survival in pigs, 1. Ovulwiion rate and its influence on prenatal survival and litter size in pigs. Commonw. Bur. Anim. Health Review Ser., No. 9. 108 pp.

WRIGHT, J. W.

1972. Electric fence to keep out wild pigs. Queensland Agric. J. 98(7) :371-72.

ZEUNER, F. E.

1963. A history of domesticated animals. New York : Harper and Row. 560 pp.

Zivkovic, S., V. Jovanovic, I. Is akovic, and M. Milosevic

1971. Chromosome complement of the European wild pig (Sus scrofa L.). Experientia $27(2): 224-26$.

ZUCKERMAN, S.

1953. The breeding seasons of animals in captivity. Proc. Zool. Soc. London 122:827.

ZUROWSKI, W., and M. SAKOWICZ

1965. Effects of succinylcholine chloride on wild boars. J. Wildl. Manage. 29(3) :626-29. 
